\title{
7. EOCENE BENTHIC FORAMINIFERAL BIOFACIES OF THE NEW JERSEY TRANSECT1
}

\author{
Kenneth G. Miller and Miriam E. Katz, Lamont-Doherty Geological Observatory of Columbia University²
}

\begin{abstract}
Benthic foraminiferal biofacies may vary independently of water depth and water mass; however, calibration of biofacies and stratigraphic ranges with independent paleodepth estimates allows reconstruction of age-depth patterns applicable throughout the deep Atlantic (Tjalsma and Lohmann, 1983). We have attempted to test these faunal calibrations in a continental margin setting, reconstructing Eocene benthic foraminiferal distributions along a dip section afforded by the New Jersey Transect (DSDP Sites 612, 108, 613). The following independent estimates of Eocene depths for the transect were obtained by "backtracking," "backstripping," and by assuming increasing depth downdip ("paleoslope"): Site 612, near the middle/lower bathyal boundary (about $1000 \mathrm{~m}$ ); Site 108, in the middle bathyal zone (about $1600 \mathrm{~m}$ ); and Site 613, near the lower bathyal/upper abyssal boundary (about $2000 \mathrm{~m}$ ). Within uncertainties of backtracking (hundreds of meters), these estimates agree with estimates of paleodepth based on comparison of the New Jersey margin biofacies with other backtracked faunas. The stratigraphic ranges of many benthic taxa correspond to those found at other Atlantic DSDP sites.

The major biofacies patterns show: (1) a depth dichotomy between an early to middle Eocene Nuttallides truempyidominated biofacies (greater than $2000 \mathrm{~m}$ ) and a Lenticulina-Osangularia-Alabamina cf. dissonata biofacies (1000$2000 \mathrm{~m}$ ); and (2) a difference between a middle and a late Eocene biofacies at Site 612. The faunal boundary at about $2000 \mathrm{~m}$, between bathyal and abyssal zones, occurs not only on the margin, but also throughout the deep Atlantic. The faunal change between the middle and late Eocene at Site 612 was due to a decrease of Lenticulina spp., the local disappearance of $N$. truempyi, and establishment of a Bulimina alazanensis-Gyroidinoides spp. biofacies. Although this change could be attributed to local paleoceanographic or water-depth changes, we argue that it is the bathyal expression of a global deep-sea benthic foraminiferal change which occurred across the middle/late Eocene boundary.
\end{abstract}

\section{INTRODUCTION}

Drilling by DSDP Legs 11,93 , and 95 constitute the seaward end of a transect of the passive U.S. continental margin off New Jersey (Fig. 1). Leg 95 drilled two sites$612\left(1404 \mathrm{~m}\right.$ present depth; $\left.38^{\circ} 49.21^{\prime} \mathrm{N}, 72^{\circ} 46.43^{\prime} \mathrm{W}\right)$ and 613 ( 2323 m present depth; $\left.38^{\circ} 46.26^{\prime} \mathrm{N}, 72^{\circ} 30.43^{\prime} \mathrm{W}\right)-$ and recovered thick Eocene and upper Miocene to Recent sections. These sections are interrupted by numerous unconformities caused by downslope erosion (Miller, Curry, et al., 1985; Miller, Mountain, et al., 1985; Mountain, this volume; Poag and Mountain, this volume); little Oligocene to middle Miocene sediments were recovered. Nevertheless, the thick middle Eocene sections recovered (Site 612: $176 \mathrm{~m}$ Site 613: $161 \mathrm{~m}$ ) contain wellpreserved deep-sea benthic foraminiferal assemblages. Samples from Sites 108 (1815 m present depth; $38^{\circ} 48.27^{\prime} \mathrm{N}, 72^{\circ} 39.21^{\prime} \mathrm{W}$ ) and 390 ( $2665 \mathrm{~m}$ present depth; $30^{\circ} 08.54^{\prime} \mathrm{N}, 76^{\circ} 06.74^{\prime} \mathrm{W}$ ) also were used in mapping biofacies. We reconstruct the Eocene distribution of benthic foraminifers along a dip section on this margin from about $1000 \mathrm{~m}$ to nearly $3000 \mathrm{~m}$.

Benthic foraminifers have been used widely to infer paleodepths and other paleoenvironmental information. Early distributional studies noted correlations between depth and modern benthic foraminiferal biofacies (Phleger and Parker, 1951; Bandy, 1953a; among others), and these correlations were applied to extant taxa in the fossil re-

\footnotetext{
${ }^{1}$ Poag, C. W., Watts, A. B., et al., Init. Repts. DSDP, 95: Washington (U.S. Govt. Printing Office).

2 Address: Lamont-Doherty Geological Observatory of Columbia University, Palisades, NY 10964.
}

cord to infer paleodepths (e.g., Bandy, 1953b). Despite this emphasis on depth, early studies recognized that factors other than depth controlled the distribution of biofacies, and noted correlations with other environmental parameters, particularly temperature (e.g., Phleger and Parker, 1951; Bandy, 1953a).

Subsequent studies established not only that depth limits of deep-sea taxa varied interregionally, but also that some benthic foraminiferal biofacies varied independently of paleodepth, migrating over $2000 \mathrm{~m}$ from glacial to interglacial periods (Lohmann, 1978a). Deep-sea benthic foraminiferal distributions were shown to be correlated instead with water masses (Streeter, 1973; Schnitker, 1974, 1979; Lohmann, 1978b; Corliss, 1979). Deep-sea water masses have very small temperature and salinity variations, and benthic foraminifers presumably are not sensitive to these slight differences. Associations of benthic foraminifers with water masses exist because water masses are strongly correlated with certain physiochemical parameters (carbonate availability, organic carbon content of sediment, dissolved oxygen content, etc.) (Bremer and Lohmann, 1982; Miller and Lohmann, 1982). These physiochemical controls can be isolated, and in conjunction with carbon isotopic data, certain benthic foraminifers can provide means for interpreting paleoceanographic changes.

Independent paleoenvironmental indicators must be used to evaluate benthic foraminiferal changes in order to avoid equivocal results. We particularly are limited in the Paleogene by the paucity of extant species, and are required to adopt a different approach to paleodepth estimates. This tool is provided by "backtracking" using empirical age-versus-subsidence curves (Sclater et al., 


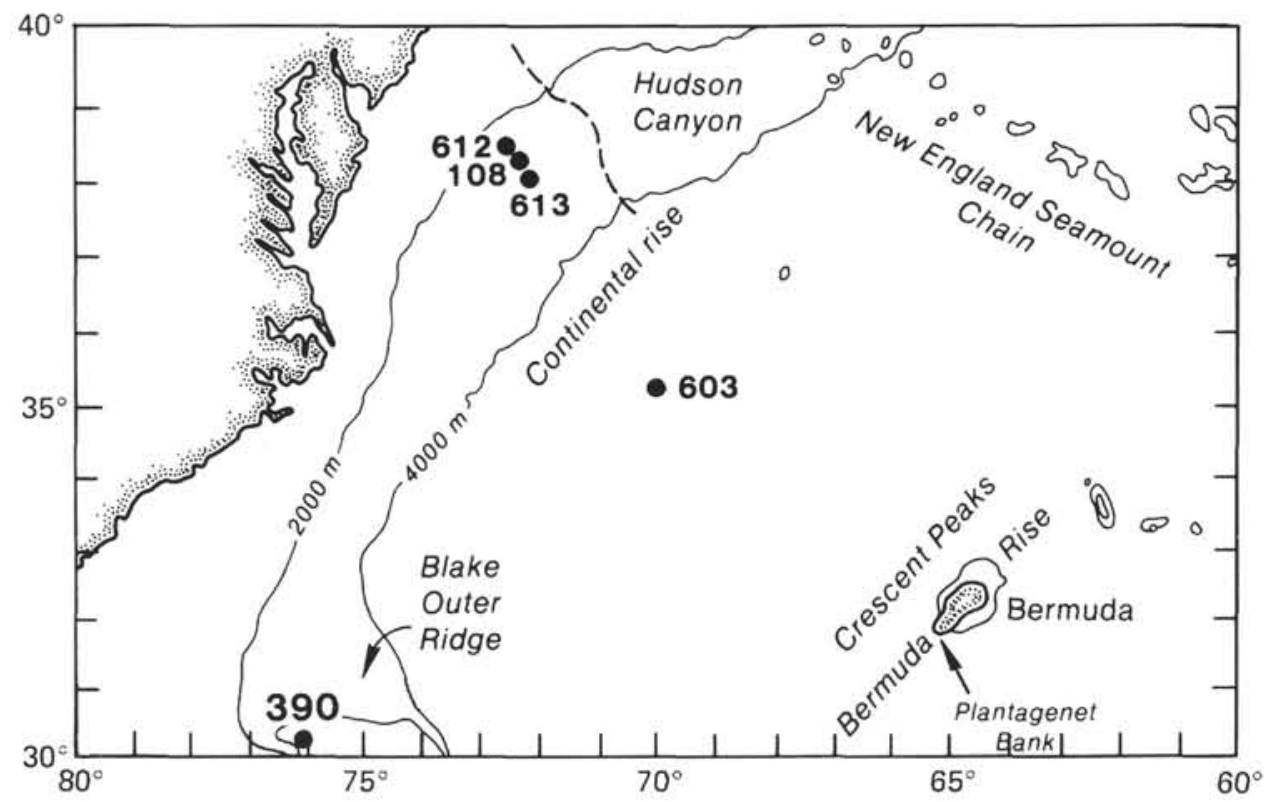

Figure 1. Location map.

1971; Berger and Winterer, 1974; Tucholke and Vogt, 1979). In addition, other geological and geophysical means can be used to place constraints upon paleodepth. For example, evidence of subaerial or shallow-water sediments can be used to constrain subsidence history of aseismic ridges (e.g., Barker, 1983), and seismic stratigraphy can be used to constrain amount of uplift in more complex regions (Miller, 1983). Changes in the distribution of benthic foraminiferal biofacies can be calibrated against these independent estimates of paleodepths (Tjalsma and Lohmann, 1983). Once the distributions are known, benthic foraminifers may be used to estimate paleodepths in other sections (e.g., Wood et al., 1985).

Tjalsma and Lohmann's (1983) calibrations of agedepth relationships of Paleocene to Eocene taxa provide a standard for comparison with the New Jersey Transect. Two factors, however, may complicate our interpretations of paleodepth based on their study: (1) Tjalsma and Lohmann lacked coverage of Eocene depths shallower than about $1400 \mathrm{~m}$, so independent evidence of the paleodepths of sites shallower than this is limited; (2) their material was derived primarily from DSDP sites away from continental margins, and there may be significant faunal differences in a margin setting. Nevertheless, comparisons between their material and ours proved valuable, especially in estimating paleodepths of the deeper Sites 108 and 613.

Examination of benthic foraminiferal distributions in a dip section such as that provided by the New Jersey Transect provides another constraint upon paleodepth, albeit a relative one. Assuming simple thermal subsidence without major Eocene faulting, paleodepths can be assumed to have increased monotonically downdip (i.e., updip wells always penetrate shallower facies). The assumption of simple thermal subsidence is reasonable for the New Jersey margin (Watts and Steckler, 1979). Assuming reasonable depth gradients appropriate for the paleophysiographic setting (shelf, slope, or rise), a slope profile may be constructed for the Eocene margin, as has been done for the Campanian to Maestrichtian of the New Jersey margin (Olsson and Nyong, 1984; Nyong and Olsson, 1984). Using this approach, downdip trends may be calibrated to relative increasing paleodepth, although the precise paleodepth is still uncertain.

We map Eocene biofacies and evaluate bathymetric trends along the New Jersey transect (Fig. 1). Our strategy in evaluating bathymetric trends is based primarily upon faunal comparisons with "backtracked" biofacies (Tjalsma and Lohmann, 1983; Miller, 1983; Miller, Curry, et al., 1985) and geophysical estimates of subsidence of the margin. Bathymetric constraints also are imposed by the assumption of increasing depth downdip and other micropaleontological evidence.

\section{METHODS}

Benthic foraminifers were studied from samples taken from the lower Eocene to lowermost Oligocene sections recovered at Site 612 (29 samples), the lower to middle Eocene section at Site 613 (11 samples), and the middle Eocene section of Site 108 ( 2 samples) off the New Jersey coast (Fig. 1). The samples were soaked in a 3\% hydrogen peroxide solution and washed through a $63-\mu \mathrm{m}$ sieve with a sodium hexametaphosphate solution. Aliquots from the $>149-\mu \mathrm{m}$ size fraction were picked and mounted on a reference slide. Three hundred specimens were picked when possible, but several samples contained as few as 100 specimens (Tables 1,2). Although benthic foraminiferal preservation was good in the middle Eocene at Sites 612 and 613 , it was poor to moderate below the diagenetic front, which lies near the lower/middle Eocene boundary at those sites (Figs. 2, 4). Therefore, interpretations of the lower Eocene faunas at these sites are less certain.

The benthic foraminifers were identified using the taxonomy outlined by Tjalsma and Lohmann (1983), Miller (1983), and the Taxonomic Notes in this chapter. The census data are presented as percentages of the total benthic foraminifers counted (Tables 1,2 ). We used computer programs provided by Lohmann (1980 and personal communication, 1982) to conduct Q-mode principal component and factor analyses of the census data. Our census contained 63 categories (Tables 1,2). Our multivariate analyses are based upon 48 of these census categories that also were used by Tjalsma and Lohmann (1983) and Miller (1983). We did a factor analysis of the combined data from Sites 108, 390 (data after Tjalsma and Lohmann, 1983), 612, and 613. 
In addition, we projected our samples from Sites 108, 612, and 613 onto Tjalsma and Lohmann's Eocene Principal Components. Only samples with more than 100 specimens were used in these comparisons.

Estimates of paleodepth for sites on the New Jersey Transect were obtained using "backtracking" (Sclater et al., 1971; Berger and Winterer, 1974) and "backstripping" techniques (Watts and Steckler, 1979). Backstripping estimates (accounting for flexure and decompaction) for the middle Eocene, provided by M. Steckler (personal communicatiơn, 1985), were as follows: Site 612, approximately $1050 \mathrm{~m}$; Site 613, approximately $2000 \mathrm{~m}$. Since Sites 612 and 108 were on continental or transitional crust, they cannot be rigorously "backtracked" using oceanic empirical age-subsidence curves. However, continental crust can be assumed to follow an exponential subsidence curve (Thorne and Watts, 1984) of the form

$$
P d=I d-A+A \cdot e^{(t / \tau)}-S
$$

where $P d$ is paleodepth, $I d$ is initial depth, $t$ is (age basement - age of level considered), $S$ is a sediment correction of 0.66 . (basement subbottom depth - sub-bottom depth of level considered), $\tau$ is a decay constant, and $A$ is an empirical constant. We used a $\tau$ of 62.5 , and an $A$ of about -3650 (empirically derived from Pacific Ocean crustal subsidence using data of Parsons and Sclater, 1977, their table 2, solving equation for $A$ assuming $I d=2700 \mathrm{~m}$ ). Assuming crustal ages of $180 \mathrm{Ma}$, Eocene depths were estimated as follows: (1) Site 612, 1200 to $1400 \mathrm{~m}$ (assuming $13 \mathrm{~km}$ of sediments); (2) Site 108,1600 to $1700 \mathrm{~m}$ (assuming $11 \mathrm{~km}$ of sediments); (3) Site 613,2200 to $2300 \mathrm{~m}$ (assuming $10 \mathrm{~km}$ of sediments) (sediment thicknesses after Poag, 1985). Since the depth of the Eocene sediments is only a small portion of total sediments, these estimates are relatively insensitive to the total thickness of sediments. Also, since the Atlantic margin was already an old margin in the Eocene and most of the thermal subsidence had already taken place, these estimates are relatively insensitive to the value of $A$ used ( $A$ can vary for Atlantic Ocean crust, from about -3300 to greater than -4100 [computed using empirical data of Tucholke and Vogt, $1979]$ ) and to the exact time of rifting (viz. whether 180 or $165 \mathrm{Ma}$ ). The resulting paleodepth section (Fig. 6) has a gradient of about 1:20, which is similar to the modern slope gradient in this region (e.g., average modern gradients on the slope are 1:15; Heezen et al., 1959).

Site 390 is on the Blake Nose off the southeastern U.S.; the Eocene benthic biofacies reported from this site (Tjalsma and Lohmann, 1983) are remarkably similar to that at Site 613. Tjalsma and Lohmann (1983) estimated backtracked paleodepth for this site of $2700 \mathrm{~m}$; using Eq. 1 (sediment $=0.38 \mathrm{~km})$, we estimate slightly shallower depths of 2300 to $2500 \mathrm{~m}$. Site 390 benthic foraminifers were compared with the New Jersey Transect by plotting biofacies at an assumed Eocene depth of 2700 m (Fig. 6).

We emphasize that the absolute paleodepths obtained by backtracking or backstripping are only broad estimates. Although Steckler's "backstripping" estimates probably are more reliable, we plotted paleodepth (e.g., Fig. 6) using the slightly deeper depths afforded by assuming subsidence along the oceanic curve. Uncertainties in the thermal subsidence estimates may be up to a few hundred meters; such uncertainties reflect, however, only a small part of the 1000 - to $3000-\mathrm{m}$ water depth estimates. Similarly, we assume that global changes in water depth were small relative to the total water depth (Kominz, 1984). Despite such uncertainties, we consider the following to be reasonable estimates of Eocene depths (Fig. 6): Site 612 was near the middle/lower bathyal boundary (about $1000 \mathrm{~m}$ ), Site 108 was in the lower bathyal zone $(1000-2000 \mathrm{~m})$, Site 613 was near the bathyal/abyssal boundary (about $2000 \mathrm{~m}$ ), and Site 390 was in the upper abyssal $(>2000 \mathrm{~m}$ ) zone (depth zones after Berggren, 1978).

\section{RESULTS AND DISCUSSION}

\section{Biostratigraphic Ranges and Chronostratigraphic Control}

\section{Planktonic Foraminifers}

We used planktonic foraminiferal biostratigraphy (site chapters; Miller and Hart, this volume) to correlate be- tween sites (Figs. 1, 3, 5). Numerical age assignments used in biofacies comparison (Figs. 6, 8-17) were made by interpolating between first and last appearance levels (Figs. 2, 4, 7; Table 3) at Sites 612 and 613 (datum-level ages and time scale of Berggren et al., 1985). Biostratigraphic control is good at Site 613, with primary and secondary zonal criteria of Stainforth et al. (1975) and Blow (1979) in reasonable agreement.

Planktonic foraminiferal biostratigraphic interpretations of much of the Eocene section at Site 612 are uncertain, with inversions of expected ranges. For example, in situ Morozovella aragonensis last occurs in Samples 612-35,CC, while reworked specimens extend into Sample 612-24,CC (Fig. 7). This last occurrence is the primary zonal criterion for the base of the $M$. lehneri Zone (Stainforth et al., 1975), and should correlate with the base of Zone P12 (Berggren et al., 1985). However, the first occurrence of Globigerinatheka kugleri is in Sample 612-31,CC, suggesting that this is the base of Zone P11 (Blow, 1979) and that the last occurrence of $M$. aragonensis in Sample 612-35,CC is local. To complicate matters further, Acarinina brcedermani last occurs in Sample 612-34,CC, suggesting that this is the top of Zone P11 (alternative criterion; Blow, 1979). Cores 612-34 to 612-24 therefore may be equivalent to either Zone P11 or Zone P12, and age models are correspondingly uncertain.

At Sites 612 and 613 the biostratigraphic zonal assignment of the upper part of the middle Eocene is debatable. We did not observe Orbulinoides beckmanni at either site; thus, Zone P13 ( = O. beckmanni total range zone) is not identifiable. Luterbacher (1972) reported this taxon from the upper middle Eocene strata at Site 108. Our examination of material from Site 108 failed, however, to confirm the presence of $O$. beckmanni, probably owing to our smaller-sized samples. Still, stratigraphic position suggests that the strata recovered at Site 612 are younger than this.

Jones (1983) and Berggren and Aubry (1984) reported planktonic foraminiferal fauna from the Castle Hayne Formation, North Carolina, which is quite similar to that of the upper middle Eocene at Sites 612 and 613 (with Hantkenina longispina, Subbotina frontosa, Globorotalia cerroazulensis pomeroli, Acarinina bullbrooki, Truncorotaloides rohri, T. topilensis, Morozovella lehneri, and Globigerinatheka mexicana). Although Jones (1982) originally favored assignment of this fauna to Zones P11 to P12, later (1983) he and Berggren and Aubry (1984) favored assignment to Zones P12 to P13. The primary zonal criterion for Zone $\mathrm{P} 13, O$. beckmanni, is also absent from the Castle Hayne Formation. The Castle Hayne Formation (partim) has been assigned to nannofossil Zone NP16 (Berggren and Aubry, 1984), and the upper middle Eocene strata at Sites 612 and 613 have been assigned to Zone CP14a ( = upper NP16) (Valentine, this volume). This suggests that (1) the Castle Hayne Formation (partim) correlates with the uppermost middle Eocene strata at Sites 612 and 613; (2) both are older than $42 \mathrm{Ma}$, correlating with upper Zone P12 to lower Zone P14 (Berggren et al., 1985); and (3) this upper middle Eocene interval represents widespread deposition on 
Table 1. Benthic foraminiferal census data (as percentages of total benthic foraminifers counted), Site 612 .

\begin{tabular}{|c|c|c|c|c|c|c|c|c|c|c|c|c|c|c|}
\hline Sample number ${ }^{\mathrm{a}}$ & 1 & 2 & 3 & 4 & 5 & 6 & 7 & 8 & 9 & 10 & 11 & 12 & 13 & 14 \\
\hline Depth (m sub-bottom) & $136.0^{b}$ & 136.0 & 137.6 & 139.1 & 140.6 & 141.3 & 143.6 & 145.1 & 149.3 & 154.7 & 158.8 & 164.5 & 168.3 & 174.0 \\
\hline Age (Ma) & 36.6 & 36.6 & 36.6 & 36.7 & 36.7 & 36.7 & 36.8 & 36.8 & 36.9 & 37.1 & 37.2 & 37.4 & 37.5 & 37.6 \\
\hline Total number counted & 335.0 & 393.0 & 369.0 & 196.0 & 148.0 & 173.0 & 292.0 & 129.0 & 321.0 & 329.0 & 181.0 & 421.0 & 162.0 & 242.0 \\
\hline
\end{tabular}

Species included in censuses of Tjalsma and Lohmann (1983), Miller (1983), and Miller et al. (1985)

\begin{tabular}{|c|c|c|c|c|c|c|c|c|c|c|c|c|c|c|}
\hline Prim. agglutinants & 0.0 & 0.0 & 0.0 & 0.0 & 0.0 & 0.0 & 0.0 & 0.0 & 0.0 & 0.0 & 0.0 & 0.0 & 0.0 & 0.0 \\
\hline S. spectabilis & 0.0 & 0.0 & 0.0 & 0.0 & 2.0 & 0.0 & 0.0 & 0.0 & 0.0 & 0.0 & 0.6 & 0.0 & 0.0 & 0.4 \\
\hline G. cf. laevigata & 0.0 & 0.0 & 0.0 & 0.0 & 0.0 & 0.0 & 0.0 & 0.0 & 0.0 & 0.0 & 0.0 & 0.0 & 0.6 & 0.0 \\
\hline G. pyramidata & 0.6 & 0.0 & 0.0 & 0.0 & 1.4 & 0.6 & 0.0 & 1.6 & 1.6 & 0.0 & 0.0 & 0.0 & 0.0 & 0.0 \\
\hline G. cf. pyramidata & 0.0 & 0.0 & 0.0 & 0.0 & 0.0 & 0.0 & 0.0 & 0.0 & 0.0 & 0.0 & 0.0 & 0.0 & 0.0 & 0.0 \\
\hline Vulvulina spinosa & 1.5 & 0.0 & 0.0 & 0.0 & 0.0 & 0.0 & 0.0 & 0.0 & 0.0 & 0.0 & 0.0 & 0.0 & 0.0 & 0. \\
\hline K. subglabra & 0.0 & 0.0 & 0.0 & 0.0 & 0.0 & 0.0 & 0.0 & 0.0 & 0.0 & 0.0 & 0.0 & 0.0 & 0.0 & 0.0 \\
\hline Pleurostomella spp. & 0.3 & 0.5 & 0.0 & 1.0 & 4.1 & 3.5 & 2.4 & 0.0 & 0.6 & 0.9 & 0.6 & 1.7 & 0.0 & \\
\hline Lenticulina spp. & 3.6 & 2.3 & 2.2 & 3.1 & 4.1 & 7.5 & 4.8 & 14.0 & 4.4 & 5.8 & 6.6 & 5.7 & 7.4 & \\
\hline S. aculeata & 2.7 & 1.8 & 0.0 & 0.0 & 0.0 & 5.8 & 1.0 & 0.8 & 1.2 & 0.0 & 1.1 & 0.2 & 0.0 & \\
\hline S. gracillima & 0.0 & 0.0 & 0.0 & 0.0 & 4.1 & 2.9 & 0.7 & 19.4 & 6.5 & 2.4 & 11.6 & 8.6 & 0.0 & \\
\hline S. subspinosa & 1.2 & 5.9 & 0.0 & 4.1 & 14.9 & 0.6 & 0.7 & 3.1 & 0.0 & 1.2 & 0.0 & 0.7 & 0.0 & 0.0 \\
\hline Aragonia spp. & 0.0 & 0.0 & 0.0 & 0.0 & 0.0 & 0.0 & 0.0 & 0.0 & 0.0 & 0.0 & 0.0 & 0.0 & 0.0 & 0.0 \\
\hline B. alazanensis & 5.4 & 34.6 & 42.5 & 38.3 & 2.0 & 1.7 & 0.0 & 0.0 & 30.8 & 29.2 & 18.2 & 21.6 & 35.8 & 2. \\
\hline B. tuxpamensis & 0.0 & 0.0 & 10.3 & 7.7 & 8.8 & 2.9 & 0.0 & 0.0 & 0.0 & 0.0 & 0.0 & 0.0 & 0.0 & \\
\hline Buliminella grata & 0.0 & 0.0 & 0.0 & 0.0 . & 0.0 & 0.0 & 0.0 & 0.0 & 0.0 & 0.0 & 0.6 & 0.0 & 0.0 & \\
\hline B. jarvisi & 0.0 & 0.0 & 0.0 & 0.0 & 0.0 & 0.0 & 0.0 & 0.0 & 0.0 & 0.0 & 0.0 & 0.0 & 0.0 & \\
\hline B. macilenta & 7.2 & 2.5 & 2.2 & 0.0 & 4.1 & 4.0 & 1.4 & 8.5 & 0.9 & 0.6 & 0.6 & 1.2 & 0.0 & \\
\hline B. callahani & 0.0 & 0.0 & 0.0 & 0.0 & 0.0 & 0.0 & 0.0 & 0.0 & 0.0 & 0.0 & 0.0 & 0.0 & 0.0 & 0.0 \\
\hline B. semicostata & 0.0 & 0.0 & 0.0 & 0.0 & 0.0 & 0.0 & 0.0 & 0.0 & 0.0 & 0.0 & 0.0 & 0.0 & 0.0 & 0.0 \\
\hline B. glomarchallengeri & 0.0 & 0.0 & 0.0 & 0.0 & 0.0 & 0.0 & 0.0 & 0.0 & 0.0 & 0.0 & 0.0 & 0.0 & 0.0 & \\
\hline B. trinitatensis & 0.0 & 0.0 & 0.0 & 0.0 & 0.0 & 0.0 & 0.0 & 0.0 & 0.0 & 0.3 & 1.1 & 0.0 & 0.0 & \\
\hline T. robertsi & 0.0 & 0.0 & 0.0 & 0.0 & 0.0 & 0.0 & 0.0 & 0.0 & 0.0 & 0.0 & 0.0 & 0.0 & 0.0 & \\
\hline$U$. rippensis & 0.3 & 0.3 & 0.0 & 0.0 & 0.0 & 4.6 & 0.3 & 4.7 & 0.0 & 0.0 & 0.0 & 0.0 & 0.0 & \\
\hline Q. profunda & 0.0 & 0.0 & 0.0 & 0.0 & 0.0 & 0.0 & 0.0 & 0.0 & 0.0 & 0.0 & 0.0 & 0.0 & 0.0 & \\
\hline A byssamina spp. & +0.0 & 0.0 & 0.0 & 0.0 & 0.0 & 0.0 & 0.0 & 0.0 & 0.0 & 0.0 & 0.0 & 0.0 & 0.0 & 0.0 \\
\hline Clinapertina spp. & 0.0 & 0.0 & 0.0 & 0.0 & 0.0 & 0.0 & 0.0 & 0.0 & 0.0 & 0.0 & 0.0 & 0.0 & 0.0 & 0.0 \\
\hline Nonion spp. & 0.9 & 6.9 & 0.0 & 1.0 & 2.0 & 0.0 & 2.7 & 0.0 & 7.5 & 5.8 & 0.6 & 6.7 & 3.1 & 0.0 \\
\hline P. eocenica & 1.5 & 7.4 & 0.3 & 9.2 & 6.1 & 13.9 & 12.7 & 0.0 & 12.5 & 10.3 & 15.5 & 9.7 & 11.7 & 14. \\
\hline P. quinqueloba & 1.5 & 0.5 & 5.4 & 1.0 & 3.4 & 4.6 & 2.1 & 0.0 & 1.6 & 2.4 & 1.7 & 2.1 & 4.3 & \\
\hline Gyroidinoides spp. & 5.7 & 4.3 & 3.3 & 4.6 & 4.7 & 9.2 & 7.2 & 0.0 & 2.8 & 2.4 & 4.4 & 5.7 & 11.7 & \\
\hline Anomalinoides spp. & 0.0 & 0.0 & 0.0 & 0.0 & 0.0 & 0.0 & 0.0 & 0.0 & 0.3 & 0.0 & 0.0 & 0.5 & 0.6 & 1.7 \\
\hline G. capitata-semicribrata & 0.0 & 0.0 & 0.0 & 0.0 & 0.0 & 0.0 & 0.0 & 0.0 & 0.0 & 0.0 & 0.0 & 0.5 & 0.0 & 0.4 \\
\hline G. micra & 0.9 & 0.0 & 0.5 & 0.0 & 0.0 & 1.7 & 1.0 & 0.0 & 1.2 & 1.5 & 1.7 & 0.0 & 3.7 & 1.7 \\
\hline N. truempyi & 0.0 & 0.0 & 0.0 & 0.0 & 0.0 & 0.0 & 0.0 & 0.0 & 0.0 & 0.0 & 0.0 & 0.0 & 0.0 & 0.0 \\
\hline O. umbonatus & 0.6 & 0.0 & 0.0 & 0.5 & 0.0 & 2.9 & 0.3 & 0.0 & 5.9 & 4.3 & 1.1 & 1.7 & 3.7 & 5. \\
\hline Osangularia spp. & 31.0 & 15.8 & 1.1 & 5.6 & 0.0 & 4.6 & 25.3 & 0.0 & 4.7 & 21.0 & 15.5 & 20.4 & 0.6 & 7. \\
\hline A. cf. dissonata & 3.0 & 0.3 & 4.9 & 10.7 & 22.3 & 0.0 & 0.0 & 0.0 & 0.0 & 0.0 & 0.0 & 0.0 & 0.0 & \\
\hline H. ammophila & 0.0 & 0.0 & 0.0 & 0.0 & 0.0 & 0.0 & 0.0 & 0.0 & 2.5 & 0.0 & 0.0 & 0.0 & 0.0 & \\
\hline G. subglobosa & 0.0 & 0.3 & 0.0 & 0.0 & 0.0 & 0.0 & 0.0 & 0.0 & 0.0 & 4.6 & 0.0 & 0.5 & 0.0 & \\
\hline C. grimsdalei & 0.0 & 0.0 & 0.0 & 0.0 & 0.0 & 0.0 & 0.0 & 0.0 & 0.0 & 0.0 & 0.0 & 0.0 & 0.0 & \\
\hline C. bradyi & 6.9 & 1.8 & 0.8 & 0.0 & 0.0 & 0.0 & 1.4 & 0.0 & 0.0 & 0.0 & 0.0 & 0.0 & 0.0 & 3. \\
\hline C. havanensis & 0.0 & 0.0 & 0.0 & 0.0 & 0.0 & 0.0 & 1.0 & 0.0 & 0.0 & 0.0 & 0.0 & 0.0 & 0.0 & \\
\hline C. mundulus & 3.0 & 1.0 & 4.3 & 4.6 & 2.7 & 5.8 & 4.1 & 0.0 & 7.8 & 1.5 & 3.9 & 1.9 & 1.2 & 3. \\
\hline C. tuxpamensis & 0.6 & 0.0 & 3.0 & 1.5 & 0.0 & 0.0 & 1.0 & 0.0 & 0.0 & 0.0 & 0.0 & 0.0 & 0.0 & \\
\hline C. cf. pseudoperlucidus & 0.0 & 0.0 & 0.0 & 0.0 & 0.0 & 0.0 & 0.0 & 0.0 & 0.0 & 0.0 & 0.0 & 0.0 & 0.0 & 0.0 \\
\hline C. subspiratus & 0.0 & 0.0 & 0.0 & 0.0 & 0.0 & 0.0 & 0.0 & 0.0 & 0.0 & 0.0 & 0.0 & 0.0 & 0.0 & 0.0 \\
\hline C. laurisae & 1.5 & 0.3 & 0.3 & 0.0 & 0.0 & 0.6 & 8.2 & 0.0 & 0.0 & 0.0 & 3.9 & 3.8 & 0.0 & 0.8 \\
\hline
\end{tabular}

Species not included in censuses of Tjalsma and Lohmann (1983), Miller (1983), and Miller et al. (1985)

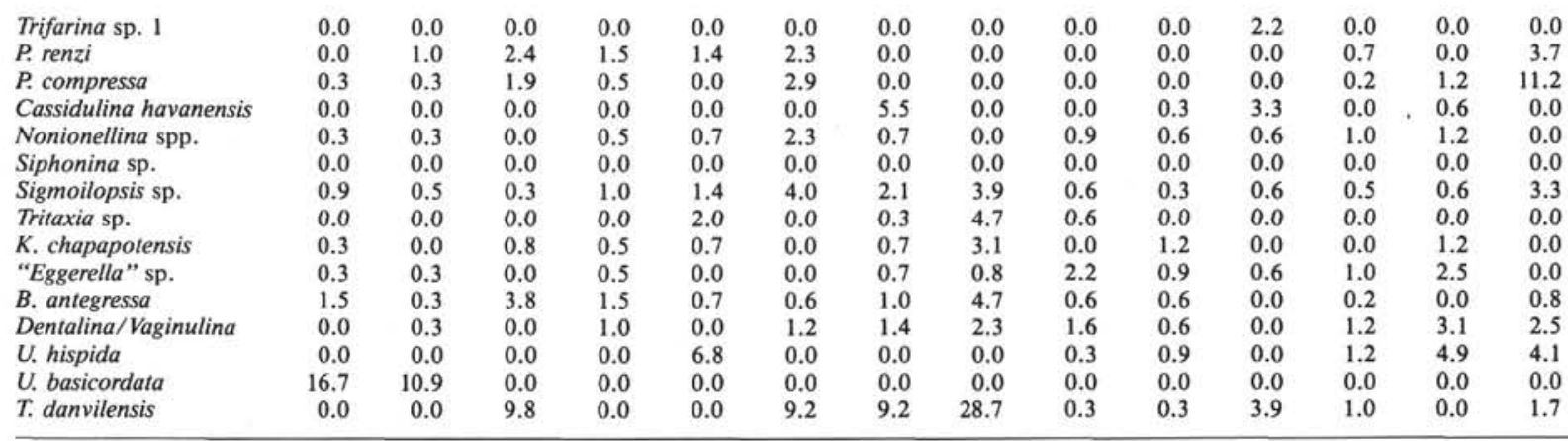

$\mathrm{a}_{1}=16-7,26-30 \mathrm{~cm} ; 2=16, \mathrm{CC} ; 3=17-1,140-144 \mathrm{~cm} ; 4=17-2,140-144 \mathrm{~cm} ; 5=17-3,140-144 \mathrm{~cm} ; 6=17-4,60-64 \mathrm{~cm} ; 7=17-5,140-144 \mathrm{~cm} ; 8$ $=17-6,140-144 \mathrm{~cm} ; 9=18-3,60-64 \mathrm{~cm} ; 10=18, C C ; 11=19-3,60-64 \mathrm{~cm} ; 12=19, \mathrm{CC} ; 13=20-3,60-64 \mathrm{~cm} ; 14=20, C C ; 15=21-1,60-64 \mathrm{~cm} ;$ $16=21-3,60-64 \mathrm{~cm} ; 17=22, \mathrm{CC} ; 18=24, \mathrm{CC} ; 19=26, \mathrm{CC} ; 20=28-6,146-150 ; 21=30, \mathrm{CC} ; 22=32, \mathrm{CC} ; 23=33, \mathrm{CC} ; 24=35, \mathrm{CC} ; 25=37-3$, $60-64 \mathrm{~cm} ; 26=39-3,60-64 \mathrm{~cm} ; 27=41-3,60-64 \mathrm{~cm} ; 28=45-3,60-64 \mathrm{~cm} ; 29=49, \mathrm{CC} ; 30=55, \mathrm{CC} ; 31=59, \mathrm{CC}$

b Actual depth sub-bottom is $135.96 \mathrm{~m}$ - because of rounding error it appears as $136.0 \mathrm{~m}$. 
Table 1 (continued).

\begin{tabular}{cccccccccccccccccc}
\hline 15 & 16 & 17 & 18 & 19 & 20 & 21 & 22 & 23 & 24 & 25 & 26 & 27 & 28 & 29 & 30 & 31 \\
174.8 & 177.8 & 193.1 & 212.0 & 231.4 & 250.4 & 269.8 & 289.0 & 298.7 & 318.0 & 331.7 & 350.9 & 370.3 & 408.8 & 453.2 & 511.3 & 549.5 \\
37.6 & 37.7 & 43.6 & 44.6 & 45.6 & 46.6 & 47.7 & 48.7 & 49.2 & 50.3 & 51.0 & 52.2 & 52.5 & 53.2 & 53.9 & 54.9 & 55.5 \\
237.0 & 244.0 & 370.0 & 277.0 & 513.0 & 541.0 & 328.0 & 273.0 & 186.0 & 502.0 & 695.0 & 163.0 & 280.0 & 89.0 & 135.0 & 89.0 & 205.0 \\
\hline
\end{tabular}

\begin{tabular}{|c|c|c|c|c|c|c|c|c|c|c|c|c|c|c|c|c|}
\hline 0.0 & 0.0 & 0.0 & 0.0 & 0.0 & 0.0 & 0.0 & 0.0 & 0.0 & 0.0 & 0.0 & 0.0 & 0.0 & 0.0 & 0.0 & 0.0 & 0.0 \\
\hline 3.4 & 0.0 & 0.0 & 0.0 & 0.0 & 0.0 & 0.0 & 0.0 & 49.5 & 3.0 & 0.6 & 3.7 & 1.4 & 0.0 & 0.0 & 0.0 & 0.0 \\
\hline 0.0 & 0.0 & 0.0 & 0.0 & 0.0 & 0.0 & 0.0 & 0.0 & 0.0 & 0.0 & 0.0 & 0.0 & 0.0 & 0.0 & 0.0 & 0.0 & 0.0 \\
\hline 0.0 & 0.0 & 0.0 & 0.0 & 0.0 & 0.0 & 0.0 & 0.0 & 0.0 & 0.0 & 0.0 & 0.0 & 0.0 & 0.0 & 0.0 & 0.0 & 0.0 \\
\hline 0.0 & 0.0 & 0.0 & 0.0 & 0.0 & 0.0 & 0.0 & 0.0 & 0.0 & 0.0 & 0.0 & 0.0 & 0.0 & 0.0 & 0.0 & 0.0 & 0.0 \\
\hline 0.0 & 0.0 & 0.0 & 0.7 & 0.0 & 5.2 & 1.8 & 2.6 & 2.2 & 0.2 & 0.4 & 8.0 & 7.1 & 3.4 & 2.2 & 0.0 & 4.4 \\
\hline 0.0 & 1.6 & 0.0 & 0.0 & 0.0 & 0.0 & 0.0 & 0.0 & 0.0 & 0.0 & 0.0 & 0.0 & 1.1 & 0.0 & 0.0 & 0.0 & 0.5 \\
\hline 0.8 & 0.8 & 0.5 & 1.4 & 0.6 & 0.9 & 0.9 & 0.4 & 0.0 & 1.8 & 0.1 & 0.0 & 0.0 & 4.5 & 3.0 & 14.6 & 2.0 \\
\hline 14.3 & 8.6 & 18.6 & 15.9 & 12.3 & 9.2 & 13.1 & 19.8 & 32.3 & 19.1 & 14.0 & 23.3 & 23.9 & 19.1 & 17.8 & 29.2 & 18.0 \\
\hline 4.6 & 2.0 & 0.0 & 0.7 & 4.9 & 9.4 & 0.0 & 0.0 & 0.5 & 3.4 & 7.2 & 0.0 & 0.0 & 2.2 & 0.0 & 5.6 & 0.0 \\
\hline 0.0 & 1.6 & 8.1 & 0.0 & 0.0 & 1.5 & 0.0 & 0.0 & 0.0 & 0.0 & 0.0 & 0.0 & 1.1 & 16.9 & 0.0 & 0.0 & 0.0 \\
\hline 0.0 & 4.1 & 1.1 & 0.0 & 3.3 & 3.0 & 0.0 & 0.0 & 1.1 & 0.0 & 0.0 & 0.0 & 0.0 & 0.0 & 0.0 & 0.0 & 0.0 \\
\hline 0.0 & 0.0 & 0.0 & 0.4 & 0.0 & 0.0 & 0.0 & 0.0 & 0.0 & 0.2 & 1.9 & 0.0 & 3.6 & 0.0 & 0.0 & 0.0 & 0.0 \\
\hline 2.1 & 11.5 & 0.3 & 0.0 & 0.0 & 0.6 & 0.0 & 0.0 & 0.0 & 0.6 & 0.1 & 0.0 & 0.0 & 0.0 & 0.0 & 1.1 & 0.0 \\
\hline 0.0 & 0.0 & 0.3 & 0.0 & 0.0 & 0.0 & 0.0 & 0.0 & 0.0 & 0.0 & 0.1 & 0.0 & 0.7 & 0.0 & 0.0 & 0.0 & 0.5 \\
\hline 0.0 & 0.0 & 0.0 & 0.0 & 0.0 & 0.0 & 0.0 & 0.0 & 0.0 & 0.0 & 0.0 & 0.0 & 0.0 & 0.0 & 1.5 & 0.0 & 0.0 \\
\hline 0.0 & 0.0 & 0.0 & 0.0 & 0.0 & 0.0 & 0.0 & 0.0 & 0.0 & 0.0 & 0.0 & 0.0 & 0.0 & 0.0 & 0.0 & 0.0 & 0.0 \\
\hline 0.0 & 0.0 & 2.7 & 1.8 & 0.0 & 2.8 & 11.6 & 0.0 & 0.0 & 0.8 & 0.3 & 8.0 & 3.9 & 0.0 & 5.2 & 1.1 & 0.0 \\
\hline 0.0 & 0.0 & 0.0 & 0.0 & 0.0 & 0.0 & 0.0 & 0.0 & 0.0 & 0.0 & 0.0 & 0.0 & 0.0 & 0.0 & 0.0 & 0.0 & 0.0 \\
\hline 0.0 & 0.0 & 0.0 & 0.0 & 0.0 & 0.0 & 0.0 & 0.0 & 0.0 & 0.0 & 0.0 & 0.0 & 0.0 & 0.0 & 0.0 & 0.0 & 0.0 \\
\hline 0.0 & 0.0 & 0.0 & 0.0 & 0.0 & 0.0 & 0.0 & 0.0 & 0.0 & 0.0 & 0.0 & 0.0 & 0.0 & 0.0 & 0.0 & 0.0 & 0.0 \\
\hline 0.4 & 0.0 & 4.1 & 1.8 & 0.0 & 0.7 & 12.5 & 0.0 & 0.0 & 3.4 & 0.7 & 0.6 & 3.6 & 4.5 & 0.7 & 1.1 & 0.0 \\
\hline 0.4 & 0.8 & 4.1 & 0.0 & 0.6 & 1.1 & 0.3 & 0.0 & 0.0 & 0.2 & 1.0 & 0.0 & 0.4 & 0.0 & 3.0 & 0.0 & 0.0 \\
\hline 0.0 & 0.0 & 0.0 & 11.9 & 0.4 & 0.0 & 0.0 & 0.0 & 0.0 & 0.0 & 0.0 & 0.0 & 0.0 & 0.0 & 0.0 & 0.0 & 0.0 \\
\hline 0.0 & 0.0 & 0.0 & 0.0 & 0.0 & 0.0 & 0.0 & 0.0 & 0.0 & 0.0 & 0.0 & 0.0 & 0.0 & 0.0 & 0.0 & 0.0 & 0.0 \\
\hline 0.0 & 0.0 & 0.0 & 0.0 & 0.0 & 0.0 & 0.0 & 0.0 & 0.0 & 0.0 & 0.0 & 0.0 & 0.0 & 0.0 & 0.0 & 0.0 & 0.0 \\
\hline 0.0 & 0.0 & 0.0 & 0.0 & 0.0 & 0.0 & 0.0 & 0.0 & 0.0 & 0.0 & 0.0 & 0.0 & 0.0 & 0.0 & 0.0 & 0.0 & 0.0 \\
\hline 0.4 & 0.4 & 0.3 & 5.4 & 0.4 & 1.8 & 3.0 & 0.0 & 0.0 & 3.4 & 0.3 & 0.0 & 0.0 & 0.0 & 0.7 & 0.0 & 2.4 \\
\hline 21.1 & 11.9 & 3.8 & 1.4 & 3.7 & 1.5 & 8.2 & 4.0 & 0.0 & 9.0 & 5.9 & 0.0 & 0.0 & 1.1 & 0.7 & 0.0 & 0.5 \\
\hline 3.8 & 6.6 & 1.9 & 0.7 & 1.2 & 1.7 & 2.7 & 1.8 & 0.0 & 2.8 & 1.4 & 0.0 & 0.0 & 1.1 & 0.7 & 1.1 & 1.5 \\
\hline 13.9 & 13.1 & 8.6 & 4.3 & 2.1 & 3.1 & 3.0 & 2.9 & 0.0 & 3.2 & 6.5 & 0.0 & 3.6 & 0.0 & 0.0 & 0.0 & 1.0 \\
\hline 1.7 & 3.3 & 0.0 & 0.4 & 0.2 & 3.5 & 17.1 & 13.9 & 0.0 & 5.6 & 4.9 & 0.0 & 0.0 & 4.5 & 5.2 & 0.0 & 1.0 \\
\hline 0.0 & 0.0 & 0.0 & 0.4 & 1.6 & 3.0 & 0.0 & 1.1 & 0.0 & 3.2 & 3.7 & 0.0 & 0.0 & 0.0 & 0.0 & 2.2 & 11.7 \\
\hline 4.2 & 3.3 & 0.0 & 8.7 & 2.3 & 0.4 & 4.9 & 0.0 & 0.0 & 6.8 & 0.7 & 1.8 & 0.4 & 1.1 & 8.1 & 0.0 & 0.0 \\
\hline 0.0 & 0.0 & 0.0 & 4.3 & 2.5 & 5.7 & 0.9 & 0.4 & 0.0 & 2.6 & 4.3 & 3.7 & 2.9 & 0.0 & 2.2 & 11.2 & 18.0 \\
\hline 2.5 & 6.1 & 6.2 & 2.9 & 0.0 & 1.8 & 0.9 & 13.2 & 0.0 & 11.8 & 5.2 & 0.0 & 10.4 & 11.2 & 6.7 & 0.0 & 2.4 \\
\hline 2.5 & 2.9 & 4.3 & 0.0 & 23.0 & 3.9 & 0.0 & 9.5 & 0.0 & 0.6 & 11.8 & 19.0 & 23.2 & 6.7 & 22.2 & 0.0 & 2.0 \\
\hline 0.0 & 0.0 & 3.0 & 22.0 & 30.0 & 12.8 & 0.0 & 20.9 & 0.0 & 0.0 & 0.0 & 17.2 & 2.5 & 0.0 & 12.6 & 0.0 & 2.4 \\
\hline 0.0 & 0.0 & 1.4 & 4.7 & 0.0 & 13.3 & 0.0 & 0.0 & 0.0 & 0.0 & 2.4 & 0.0 & 0.4 & 11.2 & 0.7 & 23.6 & 0.0 \\
\hline 0.0 & 0.0 & 0.0 & 0.0 & 1.9 & 0.6 & 3.0 & 0.0 & 0.0 & 0.0 & 2.0 & 0.0 & 0.7 & 0.0 & 0.0 & 3.4 & 0.0 \\
\hline 0.0 & 0.0 & 0.0 & 0.4 & 0.0 & 0.0 & 1.5 & 0.0 & 0.0 & 0.0 & 0.0 & 0.0 & 0.0 & 0.0 & 0.0 & 0.0 & 0.0 \\
\hline 0.4 & 0.0 & 3.8 & 0.0 & 0.0 & 0.7 & 5.5 & 1.1 & 0.0 & 4.8 & 0.0 & 0.0 & 0.0 & 0.0 & 0.0 & 0.0 & 0.0 \\
\hline 0.0 & 0.0 & 7.8 & 1.4 & 0.2 & 0.0 & 1.8 & 0.0 & 0.0 & 0.0 & 0.1 & 0.0 & 0.0 & 0.0 & 4.4 & 3.4 & 6.3 \\
\hline 11.4 & 6.1 & 2.4 & 0.0 & 6.0 & 0.0 & 3.0 & 1.1 & 0.0 & 0.0 & 14.2 & 2.5 & 4.6 & 0.0 & 1.5 & 0.0 & 25.4 \\
\hline 0.0 & 0.0 & 0.0 & 0.0 & 0.0 & 0.0 & 0.6 & 1.5 & 0.0 & 1.4 & 7.3 & 0.0 & 0.0 & 0.0 & 0.0 & 2.2 & 0.0 \\
\hline 0.0 & 0.0 & 0.0 & 0.0 & 0.0 & 0.0 & 0.0 & 0.0 & 0.0 & 0.0 & 0.0 & 0.0 & 0.0 & 0.0 & 0.0 & 0.0 & 0.0 \\
\hline 0.0 & 0.0 & 0.0 & 0.0 & 0.0 & 0.0 & 0.0 & 0.0 & 0.0 & 0.0 & 0.0 & 0.0 & 0.0 & 0.0 & 0.0 & 0.0 & 0.0 \\
\hline 0.8 & 0.8 & 1.6 & 0.0 & 1.0 & 0.0 & 0.0 & 0.0 & 0.0 & 0.0 & 0.0 & 0.0 & 0.0 & 0.0 & 0.0 & 0.0 & 0.0 \\
\hline
\end{tabular}

\begin{tabular}{|c|c|c|c|c|c|c|c|c|c|c|c|c|c|c|c|c|}
\hline 0.8 & 0.0 & 0.0 & 2.2 & 0.0 & 7.2 & 0.0 & 1.1 & 0.0 & 6.4 & 0.1 & 0.0 & 0.7 & 0.0 & 0.0 & 0.0 & 0.0 \\
\hline 0.0 & 0.0 & 0.3 & 0.0 & 0.0 & 0.0 & 0.0 & 0.0 & 0.0 & 0.0 & 0.0 & 0.0 & 0.0 & 0.0 & 0.0 & 0.0 & 0.0 \\
\hline 0.4 & 0.0 & 0.0 & 0.0 & 0.0 & 0.0 & 0.0 & 0.0 & 0.0 & 0.0 & 0.1 & 0.0 & 0.0 & 0.0 & 0.0 & 0.0 & 0.0 \\
\hline 2.5 & 3.7 & 0.0 & 0.0 & 0.0 & 0.0 & 0.0 & 0.0 & 0.0 & 0.0 & 0.0 & 0.0 & 0.0 & 0.0 & 0.0 & 0.0 & 0.0 \\
\hline 0.8 & 0.4 & 0.5 & 0.0 & 0.0 & 1.1 & 0.3 & 2.6 & 0.0 & 2.0 & 0.0 & 0.0 & 0.0 & 0.0 & 0.0 & 0.0 & 0.0 \\
\hline 0.0 & 0.0 & 0.0 & 0.0 & 0.0 & 0.0 & 0.0 & 0.0 & 0.0 & 0.0 & 0.3 & 10.4 & 3.2 & 10.1 & 0.0 & 0.0 & 0.0 \\
\hline 2.1 & 0.8 & 0.3 & 0.0 & 0.0 & 0.0 & 0.0 & 0.0 & 0.0 & 0.0 & 0.1 & 0.0 & 0.0 & 0.0 & 0.0 & 0.0 & 0.0 \\
\hline 0.0 & 0.0 & 0.0 & 0.0 & 0.0 & 0.0 & 0.0 & 0.0 & 5.4 & 0.0 & 1.2 & 1.8 & 0.7 & 0.0 & 0.0 & 0.0 & 0.0 \\
\hline 0.0 & 0.8 & 1.4 & 1.1 & 0.0 & 1.1 & 0.0 & 0.7 & 8.6 & 3.6 & 0.0 & 0.0 & 0.0 & 0.0 & 0.0 & 0.0 & 0.0 \\
\hline 1.7 & 0.4 & 0.0 & 0.4 & 0.0 & 0.0 & 0.9 & 0.0 & 0.5 & 0.0 & 0.3 & 0.0 & 0.0 & 0.0 & 0.0 & 0.0 & 0.0 \\
\hline 0.8 & 3.7 & 0.0 & 0.0 & 0.0 & 0.0 & 0.0 & 0.0 & 0.0 & 0.0 & 0.0 & 0.0 & 0.0 & 0.0 & 0.0 & 0.0 & 0.0 \\
\hline 0.8 & 2.5 & 2.4 & 4.3 & 1.8 & 2.2 & 1.5 & 1.5 & 0.0 & 0.4 & 0.4 & 0.0 & 0.0 & 2.2 & 0.7 & 0.0 & 0.0 \\
\hline 0.0 & 0.0 & 0.3 & 0.4 & 0.0 & 0.2 & 0.6 & 0.0 & 0.0 & 0.0 & 0.0 & 0.0 & 0.0 & 0.0 & 0.0 & 0.0 & 0.0 \\
\hline 0.0 & 0.0 & 0.0 & 0.0 & 0.0 & 0.0 & 0.0 & 0.0 & 0.0 & 0.0 & 0.0 & 0.0 & 0.0 & 0.0 & 0.0 & 0.0 & 0.0 \\
\hline 0.8 & 2.0 & 0.0 & 0.0 & 0.0 & 0.0 & 0.0 & 0.0 & 0.0 & 0.0 & 0.0 & 0.0 & 0.0 & 0.0 & 0.0 & 0.0 & 0.0 \\
\hline
\end{tabular}


Table 2. Benthic foraminiferal census data (as percentages of the total benthic foraminifers counted), Sites 613 and 108 .

\begin{tabular}{|c|c|c|c|c|c|c|c|c|}
\hline \multirow[b]{2}{*}{ Sample $^{\mathrm{a}}$} & \multicolumn{6}{|c|}{ Site 613} & \multicolumn{2}{|c|}{ Site 108} \\
\hline & 1 & 2 & 3 & 4 & 5 & 6 & 1 & 2 \\
\hline Depth (m sub-bottom) & 269.0 & 315.1 & 334.7 & 364.7 & 410.8 & 439.4 & 39.8 & 58.2 \\
\hline Age (Ma) & 43.0 & 45.1 & 45.9 & 47.3 & 49.3 & 52.2 & 43.0 & 44.0 \\
\hline Total number counted & 209.0 & 252.0 & 153.0 & 175.0 & 75.0 & 138.0 & 95.0 & 321.0 \\
\hline
\end{tabular}

Species included in censuses of Tjalsma and Lohmann (1983), Miller (1983), and Miller et al. (1985)

\begin{tabular}{|c|c|c|c|c|c|c|c|c|}
\hline Prim. agglutinants & 0.0 & 0.0 & 0.0 & 0.0 & 0.0 & 0.0 & 0.0 & 0.0 \\
\hline S. spectabilis & 3.3 & 10.3 & 0.0 & 0.0 & 1.3 & 0.7 & 0.0 & 0.0 \\
\hline G. ef. laevigata & 0.0 & 0.0 & 0.0 & 0.0 & 0.0 & 0.0 & 0.0 & 0.0 \\
\hline G. pyramidata & 0.0 & 0.0 & 0.0 & 0.0 & 0.0 & 0.0 & 0.0 & 0.0 \\
\hline G. cf. pyramidata & 0.0 & 0.0 & 0.0 & 0.0 & 0.0 & 0.0 & 0.0 & 0.0 \\
\hline Vulvulina spinosa & 2.9 & 3.2 & 2.6 & 2.3 & 4.0 & 2.2 & 0.0 & \\
\hline K. subgiabra & 2.4 & 0.8 & 0.0 & 0.0 & 2.7 & 0.7 & 0.0 & 0. \\
\hline Pleurostomella spp. & 1.0 & 0.4 & 2.6 & 1.7 & 0.0 & 0.7 & 0.0 & \\
\hline Lenticulina spp. & 14.4 & 13.1 & 11.1 & 9.7 & 6.7 & 36.2 & 13.7 & 21.2 \\
\hline S. aculeata & 0.5 & 0.0 & 0.0 & 0.0 & 0.0 & 5.8 & 0.0 & \\
\hline S. gracillima & 5.7 & 6.0 & 17.0 & 2.9 & 0.0 & 2.2 & 0.0 & 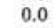 \\
\hline S. subspinosa & 1.4 & 8.3 & 5.2 & 6.3 & 0.0 & 1.4 & 0.0 & \\
\hline Aragonia spp. & 0.0 & 2.0 & 2.6 & 0.0 & 0.0 & 0.0 & 0.0 & 0.0 \\
\hline B. alazanensis & 0.0 & 0.0 & 0.0 & 0.0 & 1.3 & 0.0 & 0.0 & \\
\hline B. tuxpamensis & 0.5 & 0.0 & 0.7 & 0.0 & 0.0 & 0.0 & 1.1 & 0. \\
\hline Bulliminella grata & 0.0 & 0.0 & 0.0 & 0.0 & 0.0 & 5.8 & 0.0 & \\
\hline B. jarvisi & 0.5 & 0.0 & 0.0 & 0.0 & 0.0 & 0.0 & 0.0 & \\
\hline B. macilenta & 1.4 & 0.0 & 2.6 & 1.1 & 0.0 & 2.9 & 2.1 & \\
\hline B. callahani & 0.0 & 0.0 & 0.0 & 0.0 & 0.0 & 0.0 & 0.0 & \\
\hline B. semicostata & 0.0 & 6.3 & 0.0 & 7.4 & 12.0 & 0.0 & 0.0 & \\
\hline B. glomarchallengeri & 0.0 & 0.4 & 0.0 & 0.0 & 0.0 & 0.0 & 0.0 & \\
\hline B. Irinitatensis & 4.8 & 0.8 & 0.7 & 2.9 & 13.3 & 2.2 & 3.2 & \\
\hline T. robertsi & 0.0 & 0.0 & 0.0 & 0.0 & 0.0 & 0.0 & 0.0 & \\
\hline U. rippensis & 0.5 & 0.0 & 0.0 & 0.0 & 0.0 & 0.0 & 3.2 & \\
\hline Q. profunda & 0.0 & 0.0 & 0.0 & 0.0 & 0.0 & 0.0 & 0.0 & \\
\hline Abyssamina spp. & 0.0 & 0.0 & 0.0 & 0.0 & 0.0 & 0.0 & 0.0 & \\
\hline Clinapertina spp. & 0.0 & 0.0 & 0.0 & 0.0 & 0.0 & 0.0 & 0.0 & \\
\hline$N$, havanense & 1.4 & 0.0 & 1.3 & 0.6 & 0.0 & 0.0 & 5.3 & \\
\hline P. eocenica & 1.9 & 2.0 & 0.7 & 4.0 & 0.0 & 0.0 & 4.2 & \\
\hline P. quinqueloba & 1.0 & 2,0 & 0.0 & 0.6 & 0.0 & 0.0 & 0.0 & \\
\hline Gyroidinoides spp. & 8.6 & 6.3 & 7.2 & 5.7 & 2.7 & 0.0 & 14.7 & \\
\hline Anomalinoides spp. & 1.9 & 2.4 & 0.0 & 9,7 & 1.3 & 0.0 & 0.0 & \\
\hline G. capitata-semicribrata & 0.0 & 0.0 & 0.0 & 0.0 & 4.0 & 5.1 & 0.0 & \\
\hline G. micra & 1.9 & 1.6 & 4.6 & 0.0 & 6.7 & 0.0 & 2.1 & \\
\hline N. Iruempyi & 7.7 & 0.8 & 3.3 & 9.7 & 25.3 & 2.2 & 6.3 & \\
\hline O. umbonatus & 11.0 & 9.5 & 19.0 & 0.0 & 9.3 & 5.1 & 0.0 & \\
\hline Osangularia spp. & 0.0 & 0.8 & 0.7 & 0.0 & 0.0 & 8.0 & 2.1 & \\
\hline A. cf. dissonata & 11.0 & 0.0 & 0.0 & 0.0 & 0.0 & 0.7 & 6.3 & \\
\hline H. ammophila & 5.3 & 0.0 & 0.0 & 0.6 & 0.0 & 0.0 & 11.6 & \\
\hline G. subglobosa & 0.0 & 0.0 & 0.0 & 1.7 & 0.0 & 0.0 & 0.0 & \\
\hline C. grimsdalei & 0.0 & 0.0 & 0.0 & 0.0 & 0.0 & 0.0 & 0.0 & \\
\hline C. bradyi & 0.0 & 0.0 & 0.0 & 0.6 & 0.0 & 0.0 & 0.0 & \\
\hline C. havanensis & 0.0 & 0.0 & 0.0 & 0.0 & 0.0 & 0.0 & 0.0 & \\
\hline C. mundulus & 0.0 & 1.6 & 3.3 & 0.6 & 0.0 & 0.7 & 17.9 & \\
\hline C. tuxpamensis & 7.7 & 0.0 & 2.0 & 24.6 & 0.0 & 12.3 & 0.0 & \\
\hline C. cf. psendoperiucidus & 0.0 & 0.0 & 0.0 & 0.0 & 0.0 & 0.0 & 0.0 & \\
\hline C. subspiratus & 0.0 & 14.3 & 0.0 & 3.4 & 2.7 & 0.0 & 0.0 & \\
\hline C. laurisae & 0.0 & 0.0 & 0.0 & 0.0 & 0.0 & 0.0 & 0.0 & \\
\hline
\end{tabular}

Species not included in censuses of Tjalsma and Lohmann (1983), Miller (1983), and Miller et al (1985)

\begin{tabular}{|c|c|c|c|c|c|c|c|c|}
\hline Trifarina sp. 1 & 0.0 & 0.0 & 0.0 & 0.0 & 0.0 & 0.0 & 0.0 & 0.0 \\
\hline$P$ nenzi & 0.0 & 0.0 & 0.0 & 0.0 & 0.0 & 0.0 & 0.0 & 0.0 \\
\hline P. compressa & 0.0 & 0.0 & 0.0 & 0.0 & 0.0 & 0.0 & 0.0 & 0.0 \\
\hline Cassidulina havanensis & 0.0 & 0.0 & 0.0 & 0.0 & 0.0 & 0.0 & 0.0 & 0.0 \\
\hline Nonionellina spp. & 0.0 & 0.0 & 0.0 & 0.0 & 0.0 & 0.0 & 0.0 & 0.0 \\
\hline Siphonina sp. & 0.0 & 0.0 & 0.0 & 0.0 & 0.0 & 0.0 & 0.0 & 0.0 \\
\hline Sigmoilopsis sp. & 0.0 & 0.0 & 0.0 & 0.0 & 0.0 & 0.0 & 0.0 & 0.0 \\
\hline Tritaxia sp. & 0.0 & 0.0 & 0.0 & 0.0 & 0.0 & 0.0 & 3.2 & 0.6 \\
\hline$K$. chapapotensis & 1.4 & 0.0 & 9.2 & 1.7 & 0.0 & 0.0 & 0.0 & 0.9 \\
\hline "Eggerella" sp. & 0.0 & 1.6 & 1.3 & 1.7 & 0.0 & 0.0 & 2.1 & 0.0 \\
\hline B. antegressa & 0.0 & 0.0 & 0.0 & 0.0 & 0.0 & 0.0 & 0.0 & 0.0 \\
\hline Dentalina/Vaginulina & 0.0 & 4.4 & 2.0 & 0.6 & 6.7 & 5.1 & 1.1 & 0.9 \\
\hline U. hispida & 0.0 & 1.2 & 0.0 & 0.0 & 0.0 & 0.0 & 0.0 & 0.0 \\
\hline U. basicordata & 0.0 & 0.0 & 0.0 & 0.0 & 0.0 & 0.0 & 0.0 & 0.0 \\
\hline T. danvilensis & 0.0 & 0.0 & 0.7 & 0.0 & 0.0 & 0.0 & 0.0 & 0.0 \\
\hline
\end{tabular}

${ }^{a}$ Site $613: 1=20, \mathrm{CC} ; 2=24, \mathrm{CC} ; 3=26-6,60-64 \mathrm{~cm} ; 4=30, \mathrm{CC} ; 5=34, \mathrm{CC} ; 6=37, \mathrm{CC}$ Site 108: $1=1-1,77-80 \mathrm{~cm} ; 2=2-1,118-122 \mathrm{~cm}$.

the margin from New Jersey (Charletta, 1980; this study) to North Carolina (Jones, 1982, 1983; Berggren and Aubry, 1984).

Despite uncertainties in zonations, planktonic foraminifers suggest a major break (about 5 m.y.) across the disconformity separating the middle Eocene and upper Eocene at Site 612 (Fig. 7). The unconformity separating lower Eocene from middle Eocene strata appears to have little paleontological break, for Zones P10/P11 (un- differentiated) lie atop Zone P9. Estimates of sedimentation rate suggest, however, that some time is missing across the lower/middle Eocene disconformity. At least three age (sedimentation rate) models are applicable to the middle Eocene of Site 612 (Fig. 7): one suggests as much as a 5-m.y. break at the early/middle Eocene boundary, whereas the minimum break suggested is about 1 m.y. (see Miller and Hart, this volume, for discussion). Owing to hiatuses and problems in correlation, our reconstruction of Eocene biofacies along the transect are somewhat incomplete. Nevertheless, our sample coverage (Fig. 6) is sufficient to resolve changes in Eocene biofacies.

\section{Benthic Foraminifers}

Our compilation of benthic foraminiferal ranges from Sites 612 and 613 (Figs. 3, 5) shows that, within the sample resolution and considering hiatuses, first occurrences are relatively constant in the Eocene to lowermost Oligocene. At these sites, the first and last occurrences of many taxa correlate with first and last occurrences noted at other Atlantic DSDP sites (Table 4). There are problems in using benthic foraminifers for stratigraphic control. Local first and last occurrences caused by ecological changes are more common in benthic foraminifers than in planktonic organisms. For example, at Site 612, Nuttallides truempyi is absent from the upper Eocene (Fig. 3), although it is known to range elsewhere to the top of the Eocene (see e.g., Tjalsma and Lohmann, 1983; Wood et al., 1985). Despite such potential problems, many benthic foraminiferal ranges are consistent (Table 4) between sites. This consistency indicates that benthic foraminifers can be biostratigraphically useful, allowing recognition of major stratigraphic subdivisions (e.g., upper versus middle Eocene, etc.).

\section{Comparisons with Tjalsma and Lohmann (1983)}

The benthic biofacies at Sites 613 and 108 are similar to Tjalsma and Lohmann's "shallow" ( $<2000 \mathrm{~m})$ assemblage. This similarity is shown by moderate to high loadings on their Principal Component I (Fig. 6), which constitutes an average of their Atlantic Eocene deep-sea data. The biofacies at Sites 613, 108, and 390 are equivalent to their Lenticulina-Bulimina-Osangularia assemblage, as exemplified by high percentages of these taxa at these sites (Figs. 12B, 12C) and by moderate to high negative loadings on their Principal Components II and III. Tjalsma and Lohmann (1983) found that this assemblage predominated at lower bathyal depths $(1-2 \mathrm{~km})$ in their Eocene samples, consistent with our assignment of Sites 108 and 613 to this depth zone.

The lower and middle Eocene biofacies at Site 612 also shows moderate affinities with Tjalsma and Lohmann's (1983) Lenticulina-Bulimina-Osangularia assemblage (Fig. 6). The upper Eocene biofacies at Site 612 is, however, quite different from their assemblages. This, in part, reflects the very high abundances of Bulimina alazanensis in the upper Eocene at Site 612 (Fig. 9) and lower abundances in their data. Still, removing this taxon from the Q-mode principal component analysis shows that the difference is not due entirely to B. alazanensis, but part- 


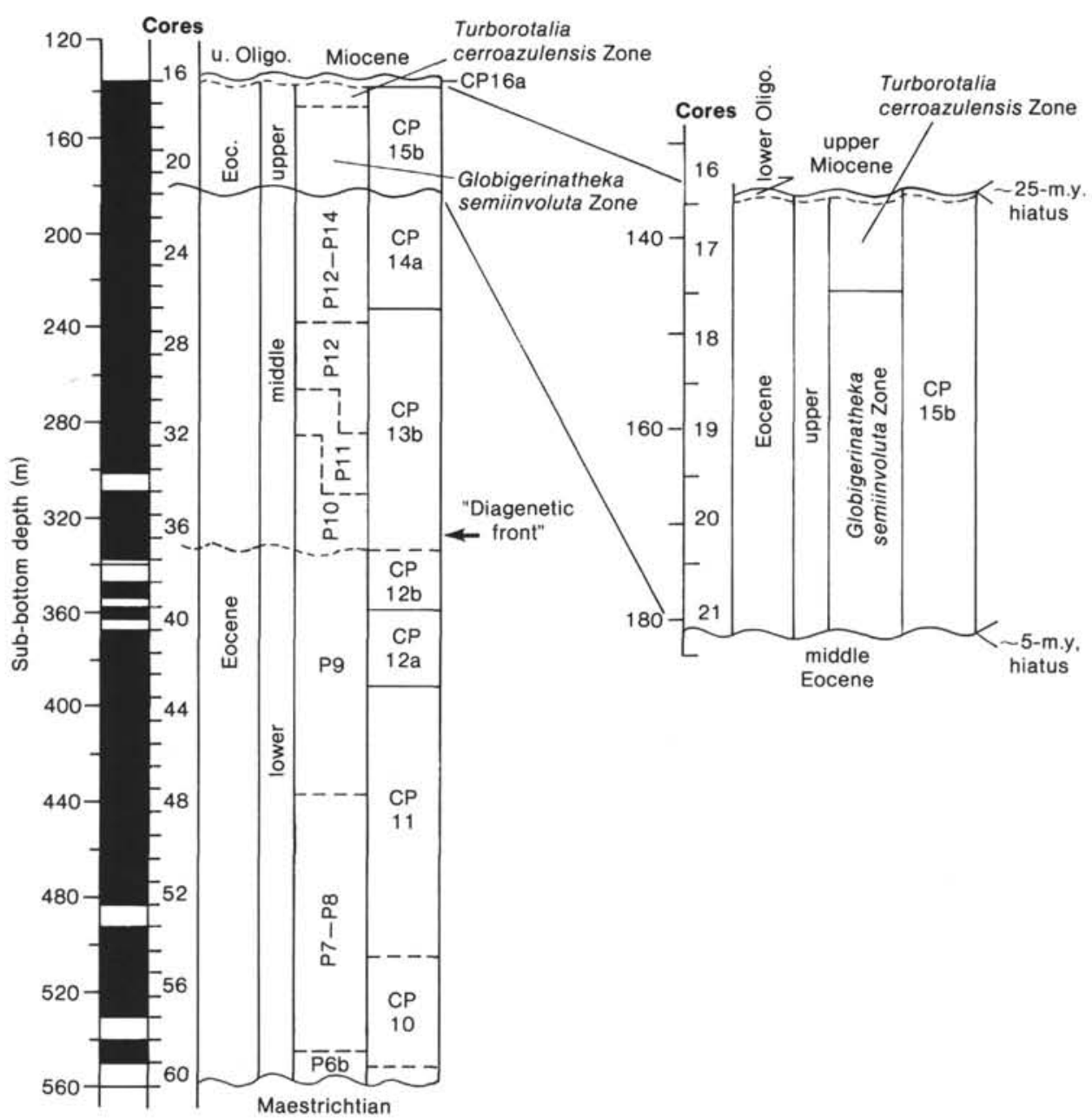

Figure 2. Paleogene section recovered at Site 612. Recovered intervals are shaded, and intervals of no recovery are open. Nannofossil zones after site chapter. Wavy lines indicate unconformities. Section on right shows upper Eocene section on a larger scale.

ly to higher abundances of Pullenia eocenica and lower abundances of Lenticulina spp. and Nuttallides truempyi. The distinct nature of the upper Eocene biofacies may be attributed to (1) a local paleoceanographic change or shallowing of the site; (2) a global benthic change in the early late Eocene; (3) Tjalsma and Lohmann's lack of late Eocene samples shallower than $1900 \mathrm{~m}$ (see discussion following).

\section{Biofacies Distribution on the New Jersey Transect}

Factor analysis and percentage data both show distinct paleodepth patterns. Factor II (Fig. 8) represents shallower taxa which were abundant only in the late Eocene at Site 612. Bulimina alazanensis (Fig. 9), Pullenia eocenica (Fig. 10), and Gyroidinoides spp. (Fig. 11) were more abundant in the late Eocene at Site 612, whereas Lenticulina spp. and Nuttallides truempyi were less abundant (Figs. 12B, 13B).

High loadings (greater than 0.4) on Factor I occurred only at middle and lower bathyal Sites 612,108 , and 613 (Fig. 12A). Lenticulina spp. dominated this biofacies (Fig. 12B). In addition, both Osangularia spp. (Fig. 12C) and Alabamina cf. dissonata (Fig. 12D) were important in the Factor I biofacies, although they were most abundant at middle bathyal Site 612 .

Sites 613 and 390 had a distinct middle Eocene biofacies represented by Factor III (Fig. 13A). Nuttallides truempyi dominated this lowermost bathyal to abyssal biofacies (Fig. 13B). Bulimina trinitatensis occurred in higher abundances in this biofacies (Fig. 13C), and $B$. semicostata was restricted to it (Fig. 14).

The most important middle Eocene downdip faunal change occurred close to the bathyal/abyssal boundary near Site 613 (Figs. 12-14). This faunal break represents the transition from the Lenticulina spp. biofacies (Factor I) to the Nuttallides truempyi biofacies (Factor III). The transition was noted by Tjalsma and Lohmann (1983) to have occurred near $2000 \mathrm{~m}$ throughout the Atlantic, indicating that this change was not restricted to the New Jersey margin.

Biofacies changes with time can be evaluated in the most complete section at Site 612. Here, the major faunal abundance change occurred during the middle/late Eocene hiatus (Figs. 6, 8-11). One of the most important faunal abundance changes of the Tertiary occurred across the middle/late Eocene boundary throughout the 


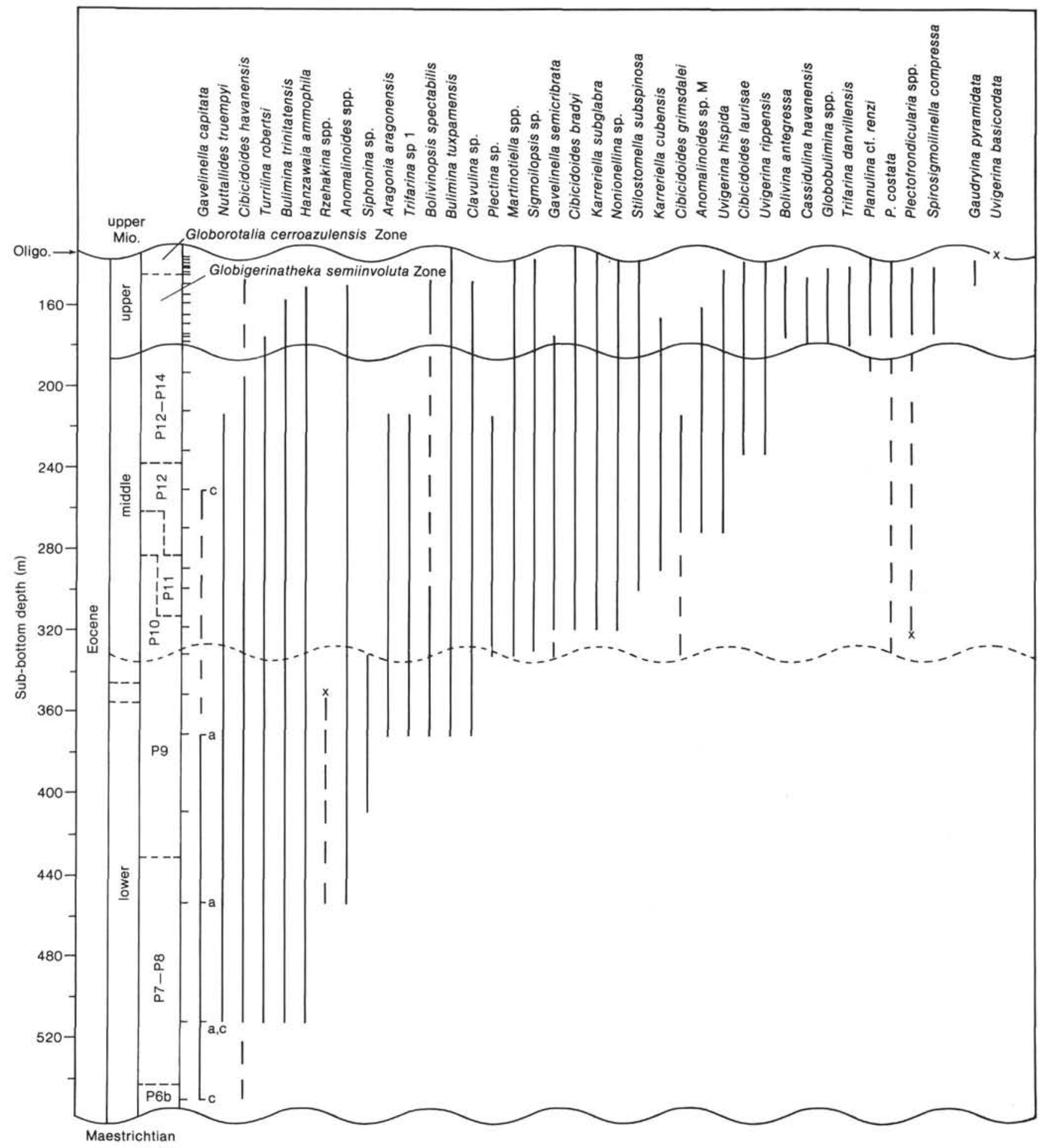

Figure 3. Range charts of benthic foraminifers, Paleogene of Site 612. Inner tick marks indicate level examined for benthic foraminifers. Dashed lines mean uncertain range; $\mathrm{x}=$ isolated occurrence; $\mathrm{a}=$ Gavelinella capitata var. aragonensis; $\mathrm{c}=$ Gavelinella capitata s.s. Planktonic foraminiferal zones as in Figure 2.

deep sea (Tjalsma and Lohmann, 1983; Miller, 1983; Miller, Curry, et al., 1985; Wood et al., 1985; Corliss and Keigwin, in press); Nuttallides truempyi, which dominated the deep-sea fauna throughout the earlier Eocene, dramatically decreased in abundance at this time. Within the afforded resolution, this event correlates with the change at Site 612.
Miller, Curry, et al., (1985) discussed the middle/late Eocene faunal abundance change at upper abyssal (estimated depth 2-2.5 km) Site 549 and lower bathyal (estimated depth 1.0-1.5 km) Site 548 on the Goban Spur. The assemblages noted at Site 548 are quite similar to those at Site 612. This is shown by projection of the Site 612 samples onto the vector defined by Principal Com- 


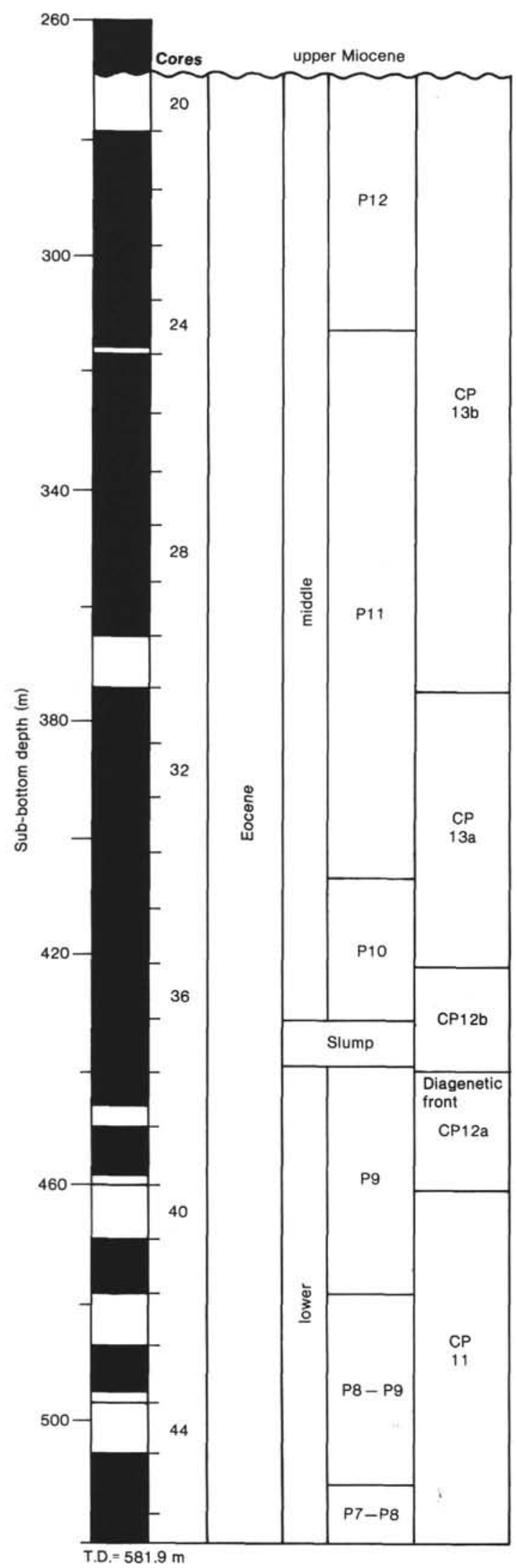

Figure 4. Portion of Eocene section studied for benthic foraminifers at Site 613. Recovered intervals are shaded, and intervals of no recovery are open. Nannofossil zones after site chapter. T.D. = total depth of hole, which bottomed in lowered Eocene. ponent II of Site 548 (Fig. 15) (Miller, Curry, et al., 1985). The faunal change noted at Site 612 is similar to that at Site 548 (Fig. 15), with a Lenticulina spp. biofacies in the middle Eocene and a Gyroidinoides spp.-Bulimina alazanensis biofacies in the late Eocene. The similarity in faunal abundances and patterns between Sites 612 and 548 further supports our estimate of an Eocene depth of about $1 \mathrm{~km}$ for Site 612 .

Although many taxa show useful, consistent paleodepth distributions, some do not. Oridorsalis spp., for example, shows no particular age-depth distribution in the Eocene (Fig. 16; fig. 15 in Tjalsma and Lohmann, 1983). We have shown elsewhere that the relative percentage of this taxon varies independently of its absolute abundance. Variations in percentage of this common taxon therefore reflect changes in absolute abundances of other taxa, and are not directly related to paleoenvironmental controls (Katz and Miller, 1985).

\section{Paleodepth, Unconformities, and Margin Erosion}

The faunal change between the middle and late Eocene at Site 612 may be attributed either to a local change (shallowing or oceanographic change) or to a global change in benthic foraminifers. There is limited evidence to indicate a shallowing between the middle and late Eocene at Site 612. The percentage of planktonic foraminifers is positively correlated with depth on margins (Grimsdale and van Morkhoven, 1955). At Site 612, there is no distinct change in percentage of planktonic foraminifers during the Eocene (Fig. 17); the ratios suggest depth of deposition in excess of 700-900 m (Grimsdale and van Morkhoven, 1955). Nuttallides truempyi is common to abundant in the lower to middle Eocene section at Site 612 , but absent from the upper Eocene section. Since this taxon has an upper depth limit of 500 to $600 \mathrm{~m}$ (Berggren and Aubert, 1983), its disappearance could be attributed to a decrease in water depth at Site 612 from middle to upper bathyal depths. However, it dramatically decreased in abundance near the middle/ late Eocene boundary (Tjalsma and Lohmann, 1983; Miller, Curry, et al., 1985; Wood et al., 1985), and its absence from the upper Eocene at Site 612 could be attributed to this global change.

We believe that the faunal change between the middle and late Eocene can be explained by oceanographic causes. As already mentioned, the faunal change upsection at Site 612 was also noted at Site 548, and may be related to the global benthic foraminiferal abundance change near the middle/late Eocene boundary. This change has been related to bottom-water changes associated with initial cooling of the deep sea near the middle/late Eocene boundary (Tjalsma and Lohmann, 1983; Miller, Curry, et al., 1985; Wood et al., 1985; Corliss and Keigwin, in press).

Following this interpretation, the difference between the upper Eocene of Site 612 and Tjalsma and Lohmann's (1983) samples may best be explained by the faunal abundance change that occurred near the middle/late Eocene boundary. Tjalsma and Lohmann's lack of upper Eocene samples from depths less than $1900 \mathrm{~m}$ prevented their delineating the effects of this change on bathyal 


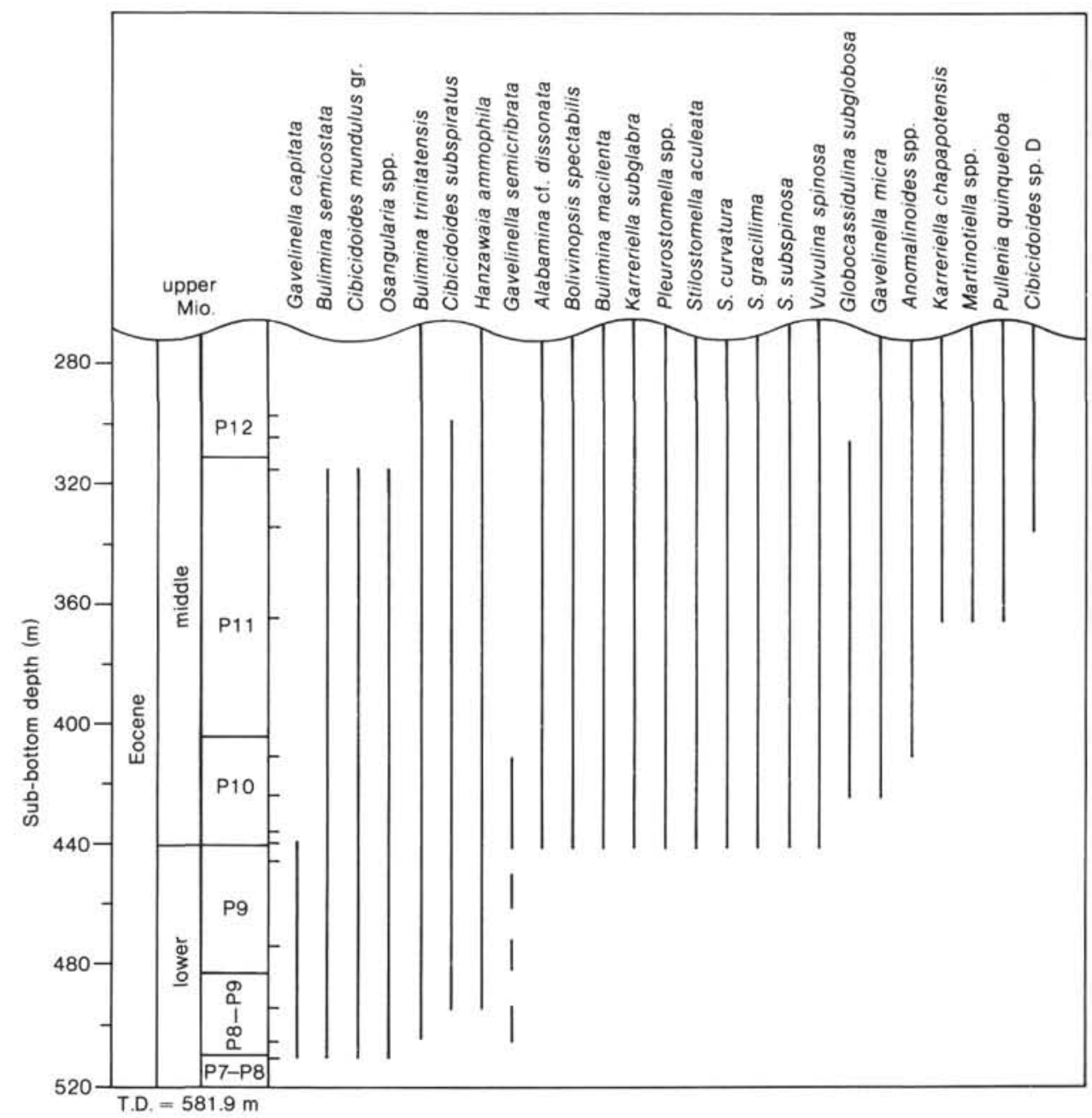

Figure 5. Range chart of benthic foraminifers, Paleogene of Site 613. Inner tick marks indicate level examined for benthic foraminifers. Dashed lines mean uncertain range. T.D. = total depth of hole.

benthic foraminifers. But the record at Site 548 (Fig. 15) allowed us to decipher the impact of the middle/late Eocene boundary faunal change at a bathyal location and to dispute an interpretation which would require a shallowing of several hundred meters across this boundary at Site 612.

Coeval unconformities have been noted across the lower/middle and middle/upper Eocene boundaries on both the New Jersey (Figs. 2, 6) and Irish (Goban Spur) margins (New Jersey margin: Poag, this volume; Miller and Hart, this volume; this study; (Irish margin: Poag et al., 1985; Miller, Curry, et al., 1985; Miller, Mountain, et al., 1985). An unconformity in the "middle" Oligocene has also been noted on both margins (Poag et al., 1985; Miller, Curry, et al., 1985; Miller, Mountain, et al., 1985). The similarity in stratigraphic position of these unconformities, also noted in northwest Europe (Aubry, 1985), suggests a global cause. The erosion associated with these unconformities correlates with coastal offlap events of Vail et al. (1977). Erosion apparently occurred during the greatest rate of sea-level fall (Pitman, 1978; Miller, Mountain, et al., 1985). Erosion occurred on the slope and rise as a result of downslope processes (Miller, Mountain, et al., 1985); Mountain, this volume; Poag and Mountain, this volume).

Paleodepth changes based upon benthic foraminifers at Sites 612,108 , and 613 do not reflect these inferred sea-level changes. This may be because magnitudes of the sea-level changes are small (30-100 m; Kominz, 1984; Miller, Mountain et al., 1985) relative to the total paleodepths at these sites, and deep-sea faunas are not sensitive to such small fluctuations in water depth. Vail et al. (1977) maintained, however, that sea-level changes were much larger (hundreds of meters). If that is true, some effect upon benthic foraminifers might have been expected at Site 612. In any case, the best locations to observe sea-level changes as benthic foraminiferal changes would be in the upper bathyal zone (e.g., near COST B-3 and B-2 wells; Charletta, 1980; Poag, 1980). We believe that future drilling is needed in upper bathyal environments not only to delineate benthic changes but also to date downslope erosional events and inferred sea-level history.

\section{CONCLUSIONS}

1. There was a distinct early to middle Eocene benthic foraminiferal biofacies boundary near $2000 \mathrm{~m}$ water 


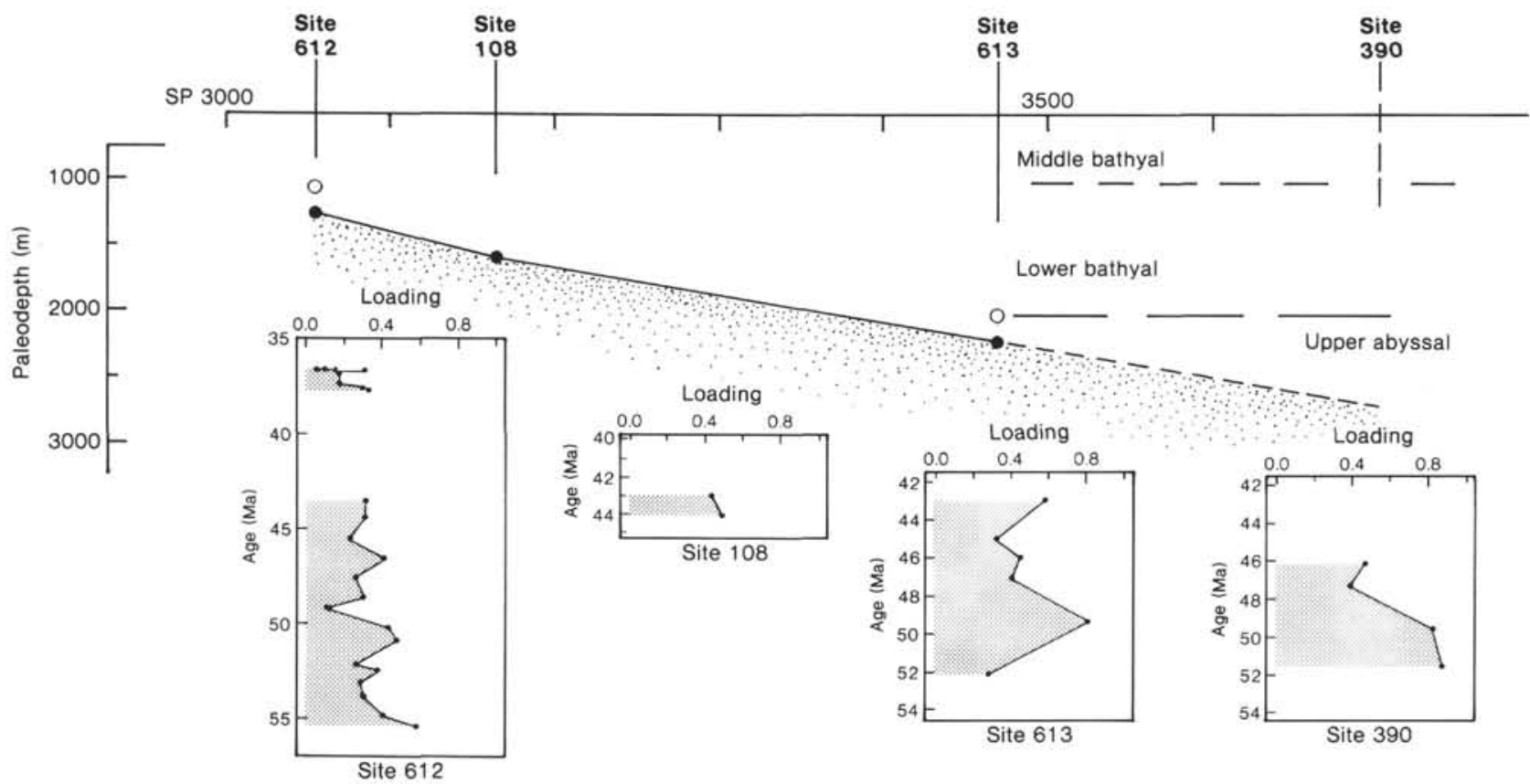

Figure 6. Projected loadings of New Jersey Transect samples onto Tjalsma and Lohmann's (1983) Principal Component I. Horizontal scale across top represents shotpoints (SP) along USGS Line $25(50 \mathrm{~m} / \mathrm{shot})$. Site 613 has been projected from about $6 \mathrm{~km}$ away. Position of Site 390 is drawn at $2700 \mathrm{~m}$ (backtracked depth), assuming a gradient of 1:25 extrapolated from Site 613 . Other paleodepth estimates (closed circles) used to derive paleoslope profile have been derived by "backtracking," assuming subsidence along an empricical age-subsidence curve; open circles represent "backstripping" estimates provided by M. Steckler (personal communication, 1985).

depth on the New Jersey margin. Nuttallides truempyi dominated the abyssal $(>2000 \mathrm{~m})$ biofacies, whereas Lenticulina spp., Osangularia spp., and Alabamina cf. dissonata constituted a middle and lower bathyal biofacies. The early to middle Eocene margin biofacies distributions are similar to those mapped in other Atlantic locations. Therefore, even though benthic biofacies may change depth through time, consistent age-depth relationships can be determined. Once these relationships are known, synoptic comparisons may be used to estimate paleodepths.

2. Stratigraphic ranges of benthic foraminifers are similar between the New Jersey margin and other Atlantic locations.

3. The only site on the New Jersey Transect where upper Eocene sediments were recovered was middle bathyal Site 612 . There, a faunal change occurred between the middle and late Eocene, with a decrease of Lenticulina spp., the local disappearance of $N$. truempyi, and the development of a Bulimina alazanensis-Gyroidinoides spp. biofacies. We interpret this change as the bathyal expression of a global deep-sea benthic foraminiferal change which occurred across the middle/late Eocene boundary.

Our study of benthic foraminifers along a dip section of the New Jersey margin documents the value of such margin transects in reconstructing paleoenvironments. Although controls on benthic foraminiferal distributions remain elusive, mapping biofacies along a depth transect provides useful age-depth information, which can be applied to interpreting environments in sections of unknown depth. Mapping biofacies versus "paleoslope" has proven useful in mapping biofacies in neritic to up- per bathyal environments (Charletta, 1980; Olsson and Nyong, 1984) and middle bathyal to abyssal environments (Nyong and Olsson, 1984; this study). Perhaps the greatest gap in our knowledge of late Paleogene faunas is in the upper to middle bathyal zones (about 300-900 m). Further drilling of sections along the New Jersey margin (i.e., near the COST B-3 well) and other margins is needed to elucidate the benthic foraminiferal biofacies in these depths, which are critical to our understanding of sealevel change.

\section{TAXONOMIC NOTES}

Species are listed here alphabetically. The taxonomic base is that of Tjalsma and Lohmann (1983) as modified by Miller (1983). In addition, we include taxonomic changes that were required after comparison of material at the U.S. National Museum (Miller and Berggren, unpublished data) and various European collections (Berggren, personal communications, 1984, 1985). We include descriptions of the most abundant taxa; in addition, we include taxa which may have been rare but which are stratigraphically useful. No attempt has been made to subdivide various species of Fissurina, Gyroidinoides, Lagena, Lenticulina, Loxostomum, Marginulinopsis/Vaginulinopsis, Nonionella, Osangularia, Oridorsalis, Plectofrondicularia, pleurostomellids, primitive agglutinants, and Textularia.

\section{Alabamina ef. dissonata (Cushman and Renz)} (Plate 3, Figs. 4-6)

Pulvinulinella atlantisae Cushman var. dissonata Cushman and Renz, 1948 , p. 35 , pl. 7, figs. 11-12.

Alabamina dissonata (Cushman and Renz). Miller, 1983, p. 431, pl. 1, fig. 8 .

Alabamina dissonata (Cushman and Renz). Tjalsma and Lohmann, 1983 , p. 22 , pl. 17 , figs. 3 a, b; pl. 20, fig. 5 .

The specimens noted here differ from typical $A$. dissonata by having only a faintly developed keel and by lacking raised sutures on the spiral side. We noted that this species was most common (up to $30 \%$ ) at the middle bathyal Site 612 (Fig. 12D). Tjalsma and Lohmann (1983) 


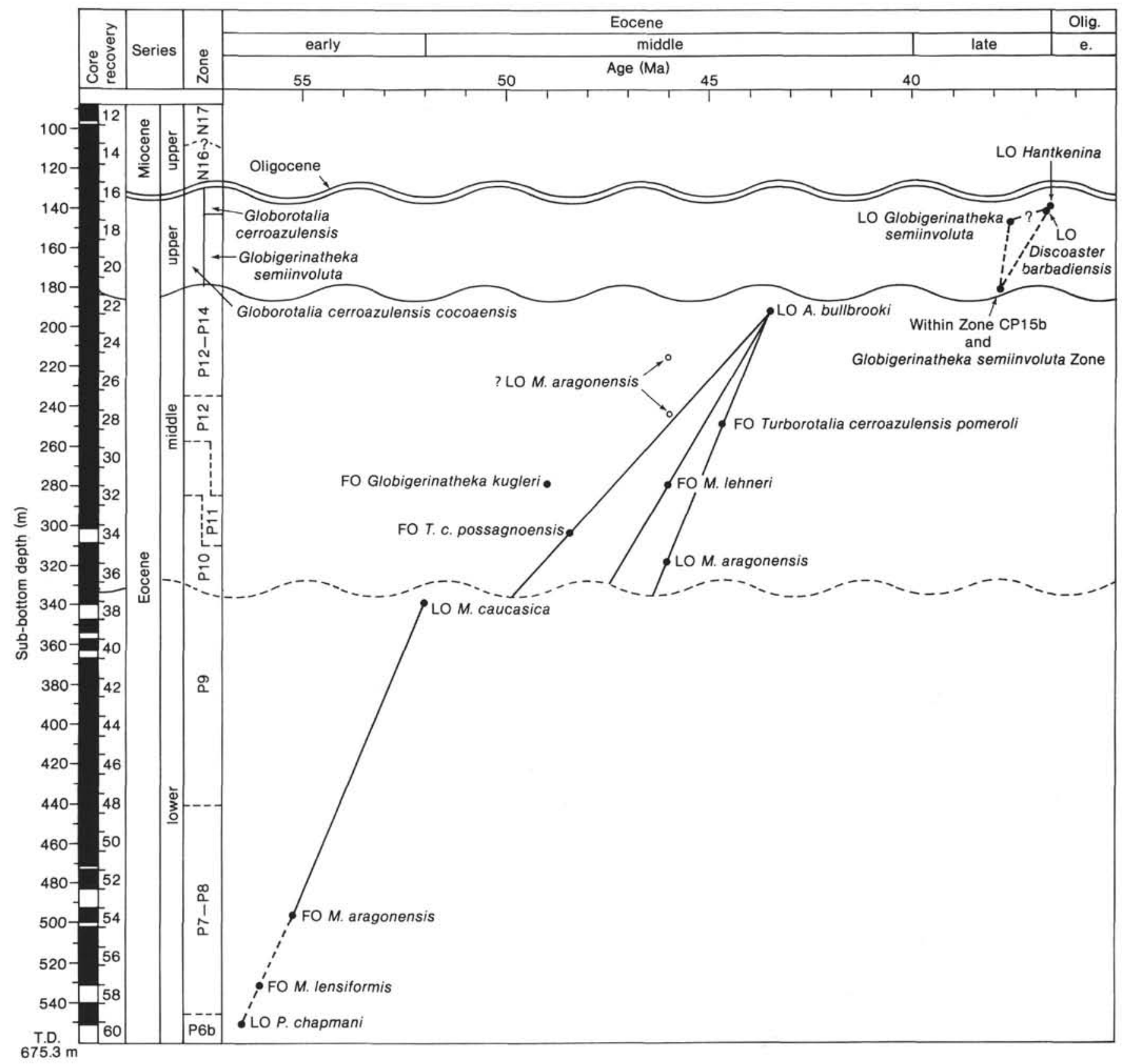

Figure 7. Age-depth plot for the Paleogene of Site 612, showing levels of planktonic foraminiferal datum levels. Datum-level ages and chronostratigraphic subdivisions drawn after Berggren et al. (1985) FO = first occurrence; LO = last occurrence. Wavy lines indicate unconformities and associated hiatuses. Open circles indicate two isolated occurrences of $M$. aragonensis, interpreted as reworked.

did not report this taxon from upper abyssal Site 390 . Typical $A$. dissonata s.s. are usually found at abyssal (mostly lower abyssal) depths (Tjalsma and Lohmann, 1983; Miller 1983). We regard A. cf. dissonata as a bathyal variant of the abyssal species $A$. dissonata. $A$. wilcoxensis Brotzen, noted in the middle nertitic New Jersey coastal plain by Charletta (1980), is smallet and lacks a keel.

\section{Anomalinoides sp. $\mathbf{M}$}

(Plate 2, Figs. 11, 12)

This form is very similar to Melonis pompilioides, except that it is slightly trochospiral. It may be the ancestor to that taxon, which has been noted first in the lower Oligocene of Cuba and Trinidad (Miller, personal observation). Found only in the upper middle to upper Eocene at Site 612 .

\section{Anomalinoides spissiformis (Cushman and Stainforth)}

Anomalina alazanensis Nuttall var. spissiformis Cushman and Stainforth, 1945, p. 71, pl. 14, figs. 5a-c.

Anomalina spissiformis Cushman and Stainforth. Tjalsma and Lohmann, 1983, p. 23, pl. 20, figs. 4a-c.

Abundant at Site 612. Absent in the lower Eocene at Site 613. Common at Site 108 .

\section{Aragonia aragonensis (Nuttall)}

Textularia aragonensis Nuttall, 1930, p. 280, pl. 23, fig. 6 .

Aragonia aragonensis (Nuttall). Tjalsma and Lohmann, 1983, p. 23, pl. 11 , figs. $2 \mathrm{a}, \mathrm{b}$.

Aragonia capdevilensis (Cushman and Bermudez). Tjalsma and Lohmann, 1983, p. 23, pl. 11, figs. 3a, b. 


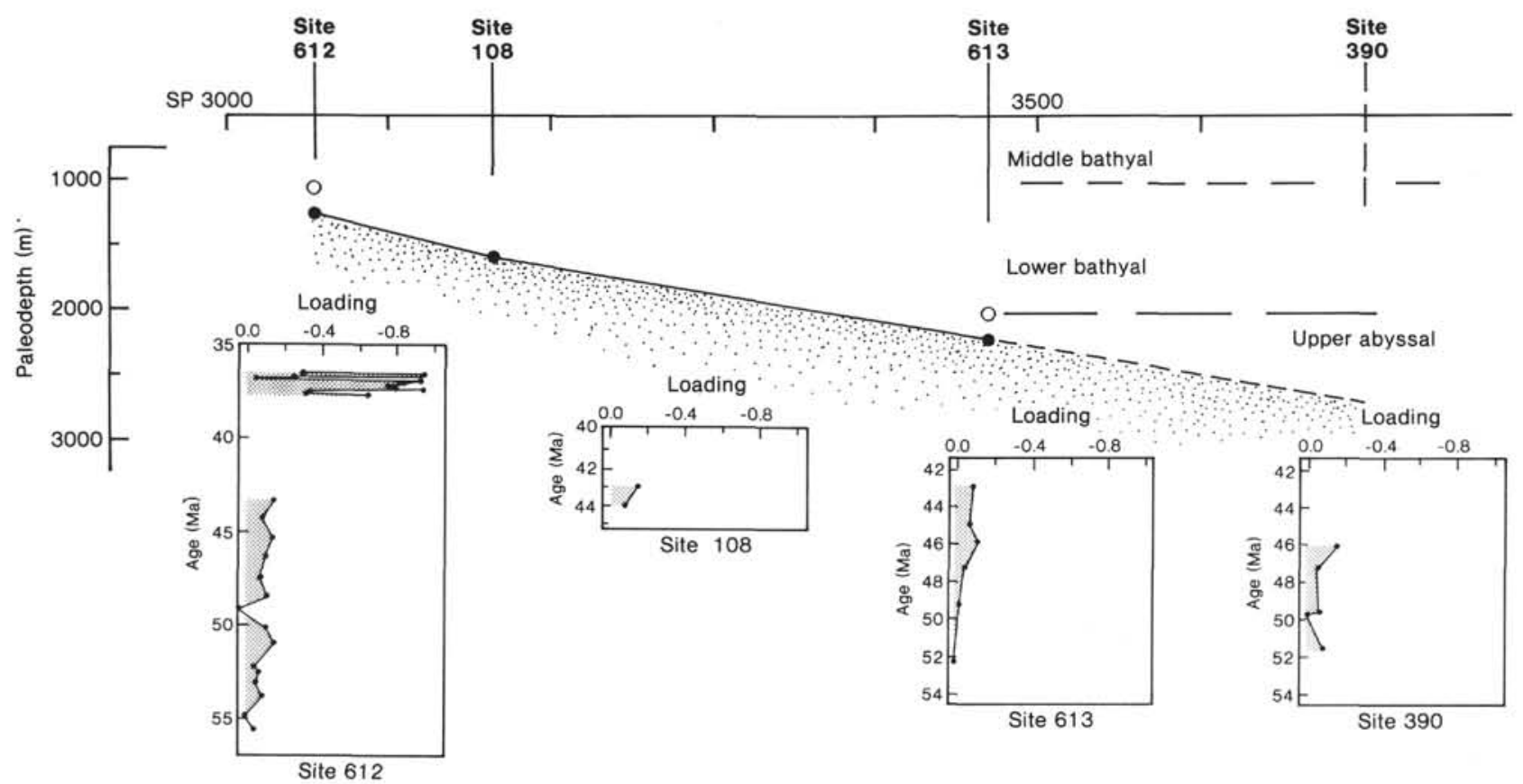

Figure 8. Loadings on Factor II computed by analysis of New Jersey Transect (Sites 612, 108, 613) and Site 390 (Tjalsma and Lohmann, 1983) census data of 48 taxa. Layout as in Figure 6.

Table 3. Interpolation points for age models (age models were derived for sites by linearly interpolating sedimentation rates between the levels shown).

\begin{tabular}{|c|c|c|}
\hline & $\begin{array}{l}\text { Sub-bottom } \\
\text { depth } \\
\text { (m) }\end{array}$ & $\begin{array}{l}\text { Age } \\
\text { (Ma) }\end{array}$ \\
\hline \multicolumn{3}{|l|}{ Site 612 - age model I (used in constructing Figs. 6, 8-17) } \\
\hline $\begin{array}{l}\text { LO Hantkenina spp. } \\
\text { Level within upper Eocene, within Zone CP15b, } \\
\text { and } G \text {. cerroazulensis Zone }\end{array}$ & $\begin{array}{l}136.2 \\
181.2\end{array}$ & $\begin{array}{l}36.6 \\
37.8\end{array}$ \\
\hline \multicolumn{3}{|l|}{ Hiatus } \\
\hline $\begin{array}{l}\text { Within range of } A \text {. bullbrooki (see text) } \\
\text { Arbitrary level within Zone P10 }\end{array}$ & $\begin{array}{l}183.0 \\
331.7\end{array}$ & $\begin{array}{l}43.0 \\
51.0\end{array}$ \\
\hline \multicolumn{3}{|l|}{ Hiatus } \\
\hline $\begin{array}{l}\text { LO } M \text {. caucasica } \\
\text { FO } M \text {. aragonensis }\end{array}$ & $\begin{array}{l}337.5 \\
530.6\end{array}$ & $\begin{array}{l}52.0 \\
55.2\end{array}$ \\
\hline Hiatus & & \\
\hline
\end{tabular}

Site 613

$\begin{array}{lll}\text { Within range of } A \text {. bullbrooki (see texi) } & 269.0 & 43.0 \\ \text { LO M. aragonensis } & 336.0 & 46.0 \\ \text { FO T. rohri } & 430.0 & 50.2\end{array}$

Possible hiatus - slow sedimentation rates $(5 \mathrm{~m} / \mathrm{m} . \mathrm{y}$.)

$\begin{array}{lll}\text { LO } M \text {. caucasica } & 440.0 & 52.0 \\ \text { FO } M \text {. caucasica } & 578.0 & 55.2\end{array}$

Note: $L O=$ last occurrence; $F O=$ first occurrence.

Aragonia aragonensis (Nuttall). Charletta, 1980. p. 68, pl. 5, fig. 11.

This taxon is rare in our material. We have not attempted to differentiate the aragoniids here, although our specimens fall into the $A$. aragonensis- $A$. capdevilensis group. Therefore, we have adopted the senior synonym. Occurs in the lower to middle Eocene of Site 612 (Zones P9-P12) and in Zone P12 at Site 613. Absent at Site 108.
Table 4. Comparison of ranges of benthic taxa.

\begin{tabular}{|c|c|c|}
\hline Taxon & Reference & Site 612 \\
\hline LO Spiroplectammina spectabilis & Top Eocene (ref. 1) & Top Eocene \\
\hline FO Hanzawaia ammophila & P6a (ref. 1) & \\
\hline FO Gavelinella capitata & $\mathrm{P} 6 \mathrm{~b}$ (ref. 1 ) & P $6 \mathrm{~b}$ (base of section) \\
\hline FO G. semicribrata & P12 (ref. 1) & $\mathrm{P} 11 / \mathrm{P} 12$ \\
\hline FO Cibicidoides laurisae & P10 (ref. 1) & P12 \\
\hline FO Uvigerina rippensis & P10, P14 (abundant) (ref. 1) & P12 \\
\hline FO Cibicidoides havanensis & P8 (ref. 1) & P7 \\
\hline FO Planulina costata & P15 (ref. 2) & P15 \\
\hline FO Uvigerina basicordata & upper Eocene (ref. 2) & Basal Oligocene \\
\hline FO Planulina renzi & P15-P16 (ref. 3) & Cf. in P15 \\
\hline FO Cassidulina havanensis & P18 (ref. 4) & P15 \\
\hline FO Bolivina antegressa & $\begin{array}{l}\text { P15 (ref. 4) } \\
\text { P18 (ref. 3) }\end{array}$ & P15 \\
\hline \multirow[t]{2}{*}{ LO Rzehakina epigona } & P12 (ref. 2) & P9 \\
\hline & & Site 613 \\
\hline TR Cibicidoides subspiratus & P9-P13 (ref. 1) & P8/9-P12 \\
\hline FO Gavelinella micra & P10 (ref. 1) & \\
\hline FO semicribrata & P12 (refs. 1, 4) & P10 \\
\hline
\end{tabular}

\section{Bolivina antegressa Subbotina \\ (Plate 2, Figs. 1, 2)}

Bolivina antegressa Subbotina, 1953, p. 226, pl. 10, figs. 11-16.

Bolivina antegressa Subbotina. Miller, Curry, et al., 1985, pl. 4, fig. 11. Common to abundant in the upper Eocene at Site 612. Absent at Sites 108 and 613 . We included forms both with and without a medial ridge (cf. figs. 12 and 14-16 of Sobbotina). Although Cushman (1926a) illustrated faint striae on his B. tectiformis, examination of his type specimen shows a faint medial ridge, but no striae. Therefore we adopted Subbotina's taxon for this striate bolivinid.

\section{Bulimina alazanensis Cushman \\ (Plate 3, Figs. 12, 13)}

Bulimina alazanensis Cushman, 1927b, p. 161, pl. 25, fig. 4.

Bulimina alazanensis Cushman, Tjalsma and Lohmann, 1983, p. 24, pl. 14, fig. 4 . 


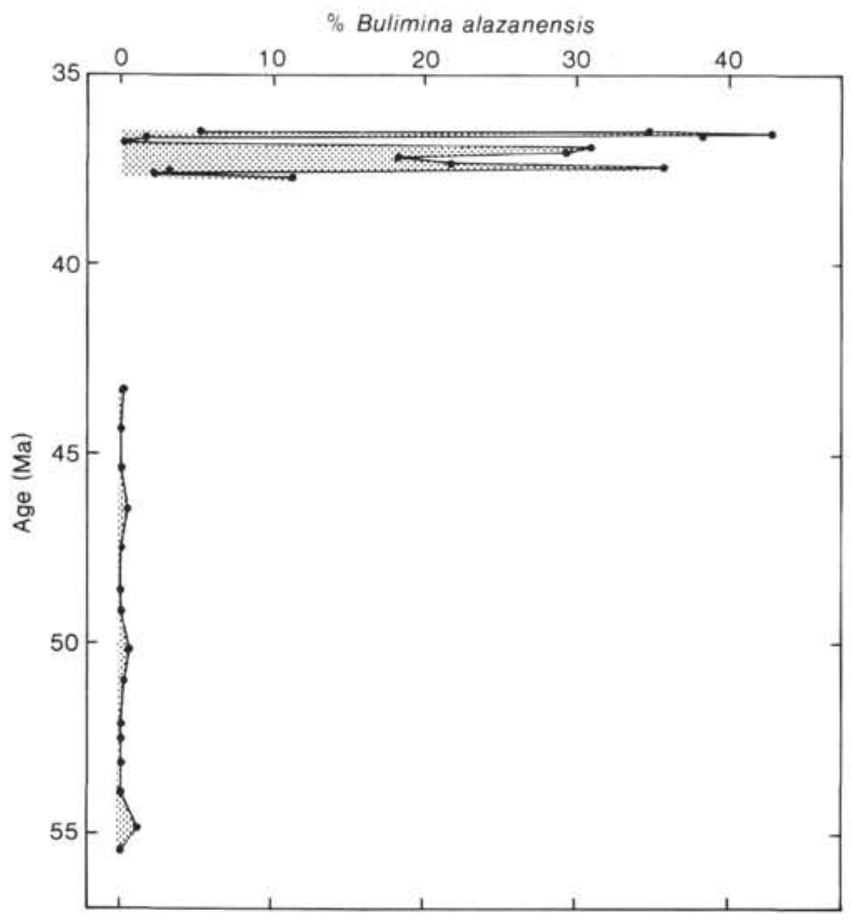

Figure 9. Percent abundance of Bulimina alazanensis at Site 612. This taxon is absent from Sites 108, 613, and 390.

Bulimina alazanensis Cushman, Miller, Curry, et al., 1985, pl. 4, fig. 6. Abundant in the upper Eocene at Site 612 and present throughout; single occurrence at Site 613. Rare at Site 108.

\section{Bulimina glomarchallengeri Tjalsma and Lohmann}

Bulimina glomarchallengeri Tjalsma and Lohmann, 1983, p. 25, pl. 13, figs. 8-12c.

Bulimina glomarchallengeri Tjalsma and Lohmann. Miller, 1983, p. 431, pl. 3, fig. 11 .
Bulimina glomarchallengeri Tjalsma and Lohmann. Miller, Curry, et al., 1985, pl. 4, fig. 1 .

$B$. semicostata is distinguished from $B$. glomarchallengerae by its triangular, tapered test. Single occurrence at Site 613 in the middle Eocene. Absent at Sites 108 and 612.

\section{Bulimina jacksonensis Cushman}

Bulimina jacksonensis Cushman, 1925, pl. 1, figs. 6, 7. Rare at Site 612. Absent at Sites 108 and 613.

\section{Bulimina macilenta Cushman and Parker}

Bulimina denticulata Cushman and Parker, 1936, p. 42, pl. 7, figs. $7 \mathrm{a}-8 \mathrm{c}$.

Bulimina macilenta Cushman and Parker, 1939 (new name), p. 93.

Bulimina macilenta Cushman and Parker. Tjalsma and Lohmann, 1983, p. 25 , pl. 14, fig. 3 .

Bulimina aff. striata mexicana Cushman-subacuminata Cushman and Stewart. Charletta, 1980, p. 66, pl. 5, fig. 14

Common at all sites.

\section{Bulimina semicostata Nuttal}

Bulimina semicostata Nuttall, 1930, p. 285, pl. 23, figs. 15, 16.

Bulimina semicostata Nuttall. Tjalsma and Lohmann, 1983, p. 25 , pl. 13, figs. 1-3.

Bulimina semicostata Nuttall. Miller, 1983, p. 433, pl. 3, fig. 12. Among our sites, present at Site 613 only. Noted by Tjalsma and Lohmann (1983) from Site 390. This taxon is therefore restricted to paleodepths $>2000 \mathrm{~m}$ on the New Jersey Transect.

\section{Bulimina trinitatensis Cushman and Jarvis \\ (Plate 3, Figs. 10, 11)}

Bulimina trinitatensis Cushman and Jarvis, 1928, p. 102, pl. 14, figs. $12 \mathrm{a}, \mathrm{b}$.

Bulimina trinitatensis Cushman and Jarvis. Tjalsma and Lohmann, 1983 , p. 7 , pl. 3 , figs. 3 , 4 ; pl. 14 , fig. 1 .

Bulimina trinitatensis Cushman and Jarvis. Miller, 1983, p. 433, pl. 3, fig. 7 .

Common at all three sites. We included B. impendens Parker and Bermudez in both the census (following Tjalsma and Lohmann, 1983) and the range charts.

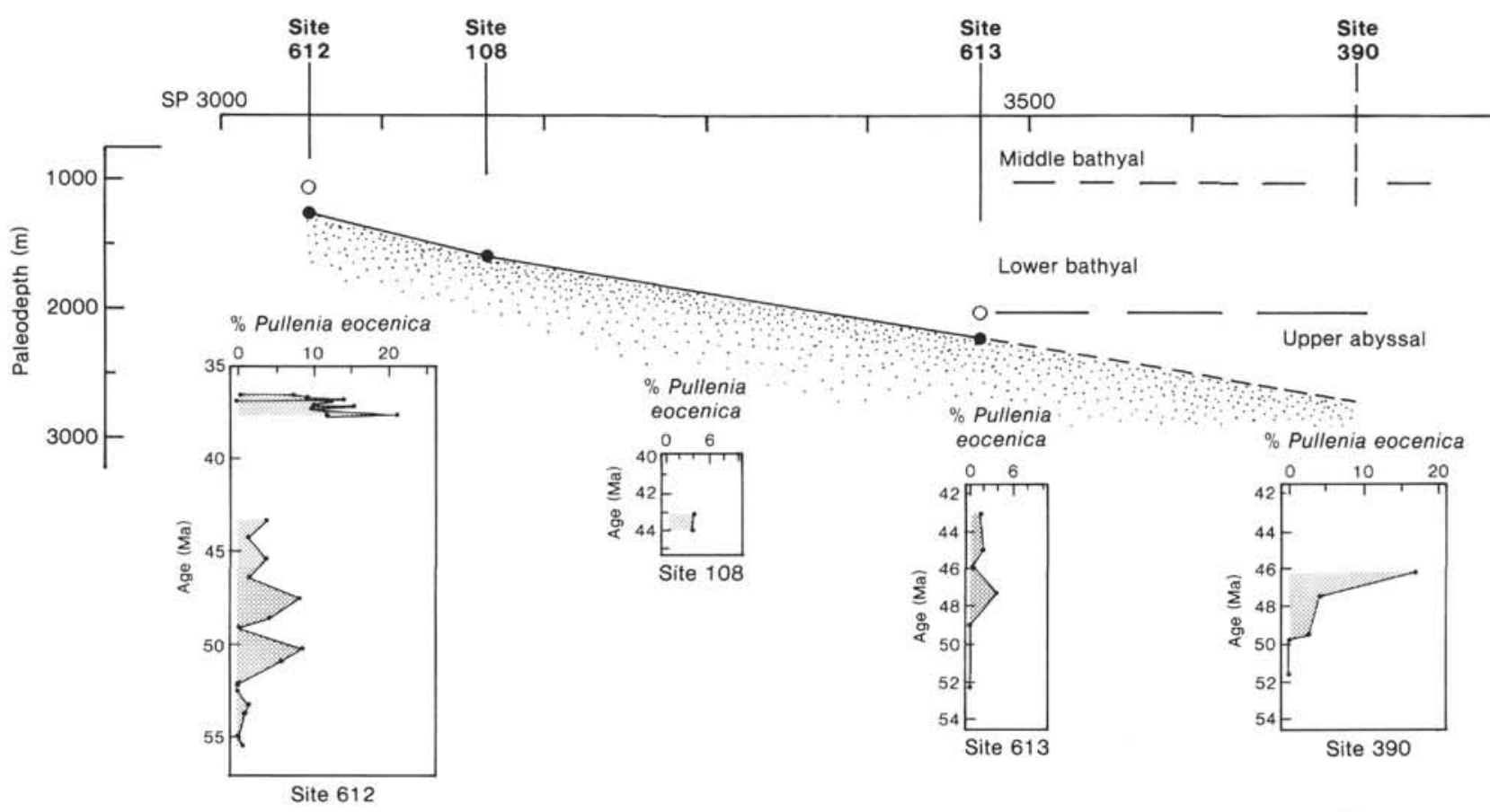

Figure 10. Percent abundance of Pullenia eocenica along paleoslope. Layout as in Figure 6. 


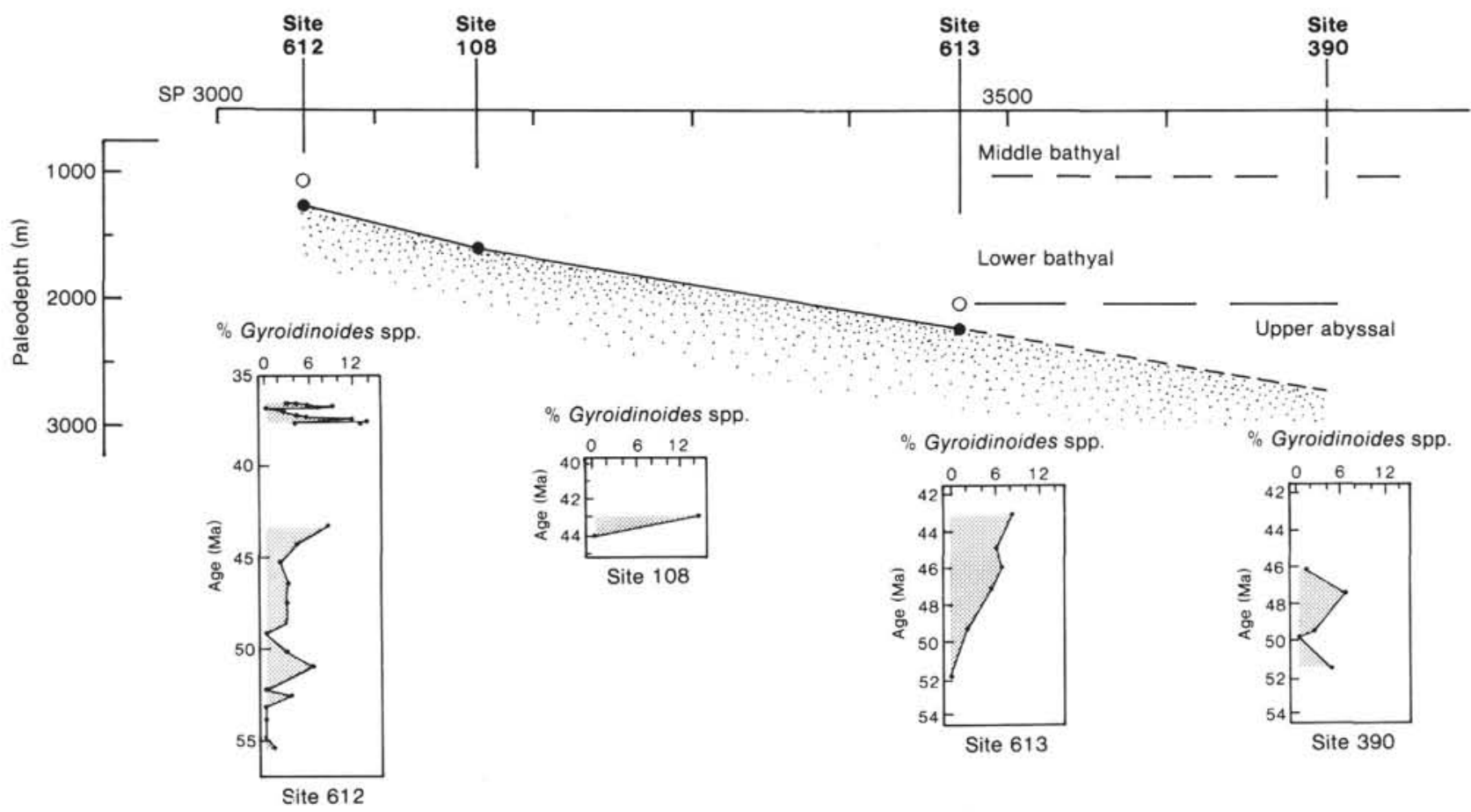

Figure 11. Percent abundance of Gyroidinoides spp. along paleoslope. Layout as in Figure 6.

Bulimina tuxpamensis Cole

(Plate 3, Figs. 14, 15)

Bulimina tuxpamensis Cole, 1928, p. 212, pl. 32, fig. 23.

Bulimina tuxpamensis Cole. Tjalsma and Lohmann, 1983, p. 26 , pl. 12 , figs. $3 a-4$.

Bulimina tuxpamensis Cole. Miller, Curry, et al., 1985, pl. 4, fig. 7.

Most common in the upper Eocene of Site 612. Rare at Site 613.

Rare at Site 108. We included forms assignable to Bulimina bradburyi

Martin (1943) in both the census (following Tjalsma and Lohmann,

1983) and the range charts.

\section{Buliminella grata Parker and Bermudez}

Buliminella grata Parker and Bermudez, 1937, p. 515, pl. 59, figs. 6a-c.

Buliminella grata Parker and Bermudez. Tjalsma and Lohmann, 1983, p. 26 , pl. 12 , figs. $7 \mathrm{a}$, b.

Rare at both Site 612 and Site 613. Common at Site 108.

\section{Cassidulina crassa d'Orbigny}

Cassidulina crassa d'Orbigny, 1839, p. 56, pl. 7, figs. 18-20.

Possible occurrences in the upper Eocene at Site 612. Absent at Sites 108 and 613.

\section{Cassidulina havanensis Cushman and Bermudez \\ (Plate 3, Figs. 1-3)}

Cassidulina havanensis Cushman and Bermudez, 1936, p. 36, 6, fig. 11. Cassidulina havanensis Cushman and Bermudez. Miller, 1983, p. 433.

Cassidulina havanensis Cushman and Bermudez. Miller, Curry, et al., 1985 , pl. 4, figs. 12,13 108 .

Restricted to the upper Eocene at Site 612. Absent at Sites 613 and

\section{Cibicidoides sp. D}

(Plate 6, Figs. 4-6)

Cibicidoides ungerianus s.1. Miller, 1983, p. 435.

This species is reminiscent of both $C$. mundulus/ungerianus group and $C$. tuxpamensis, but differs from the former in being more biconvex in axial view. Abundant in the upper middle Eocene at Site 613. Present in one sample only from Site 612. Absent at Site 108.
Cibicidoides bradyi (Trauth)

Truncatulina dutemplei Brady (not d'Orbigny), 1884, p. 665, pl. 95, fig. 5 (type figure).

Truncatulina bradyi Trauth, 1918, p. 235 (type reference).

Cibicidoides haitiensis (Coryell and Rivero). Tjalsma and Lohmann, 1983 , p. 26 , pl. 17 , figs. $6 a$, b.

Cibicidoides haitiensis (Coryell and Rivero). Miller, 1983, p. 433, pl. 2, fig. 5 .

Tjalsma and Lohmann (1983) used Coryell and Rivero's (1940) species name for Eocene-Oligocene forms, although Coryell and Rivero had illustrated an upper middle Miocene form. We find that the form illustrated by Brady and named $T$. bradyi by Trauth is difficult to distinguish from Eocene-Oligocene forms, although Eocene forms may have a flatter spiral side. Tjalsma and Lohmann (1983) placed Gyroidina jarvisi of Cushman and Stainforth (1945, p. 62, pl. 11, figs. 3a-c.) in synonomy with Cibicidoides robertsonianus var. haitiensis Coryell and Rivero. We agree that these are conspecific, but would place them as junior synonyms of the closely related Cibicidoides robertsonianus (Brady) and retain C. bradyi (Trauth) as the senior synonym of $C$. haitiensis of Tjalsma and Lohmann (not Coryell and Rivero). Abundant in the middle to upper Eocene at Site 612. Single occurrence in the middle Eocene at Site 613. Absent at Site 108.

\section{Cibicidoides grimsdalei (Nuttall)}

Cibicides grimsdalei Nuttall, 1930, p. 291, pl. 25, figs. 7, 8, 11. Cibicidoides grimsdalei (Nuttall). Schnitker, 1979, pl. 11, figs. 1-3. Cibicidoides grimsdalei (Nuttall). Tjalsma and Lohmann, 1983, p. 26, pl. 18 , figs. $2 \mathrm{a}-\mathrm{c} ;$ pl. 22 , figs. 6,7 .

Cibicidoides grimsdalei (Nuttall). Miller, 1983, p. 433, pl. 2, fig. 8

Cibicidoides grimsdalei (Nuttall). Miller, Curry, et al., 1985, pl. 1, figs. 7-9.

Present in the middle Eocene at Site 612. Absent at Sites 108 and 613.

\section{Cibicidoides havanensis (Cushman and Bermudez)}

Cibicides havanensis Cushman and Bermudez, 1937, p. 28, pl. 3, figs. 1-3.

Cibicidoides havanensis (Cushman and Bermudez). Tjalsma and Lohmann, 1983 , p. 27 , pl. 22 , figs. $4 a-c$. 


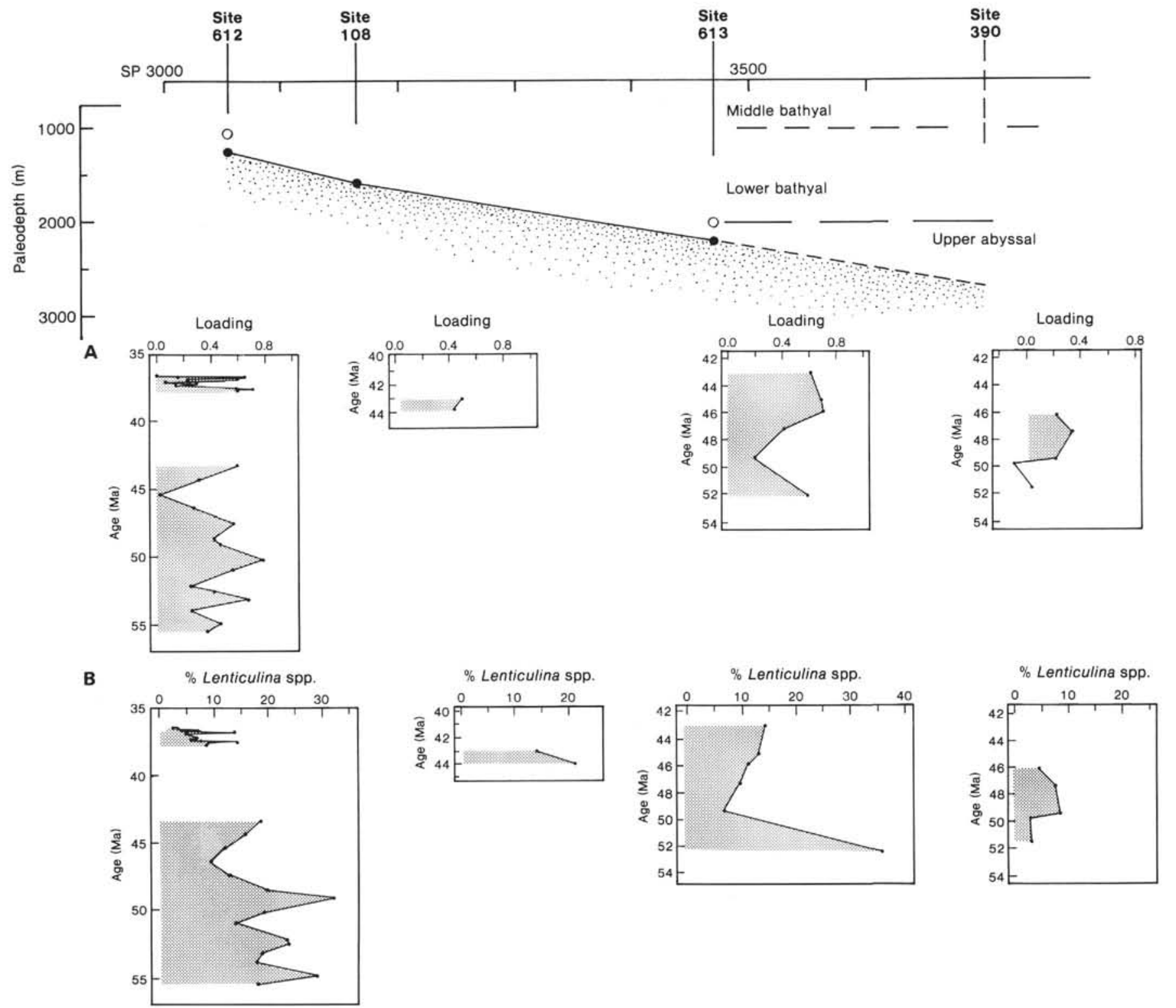


C $\quad \%$ Osangularia spp.

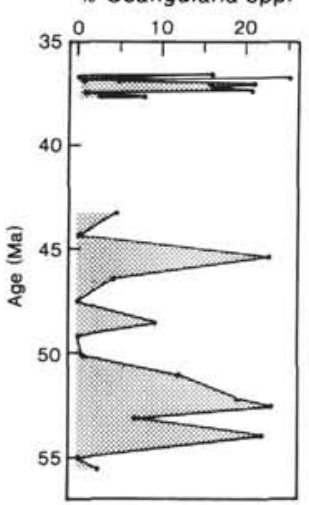

D

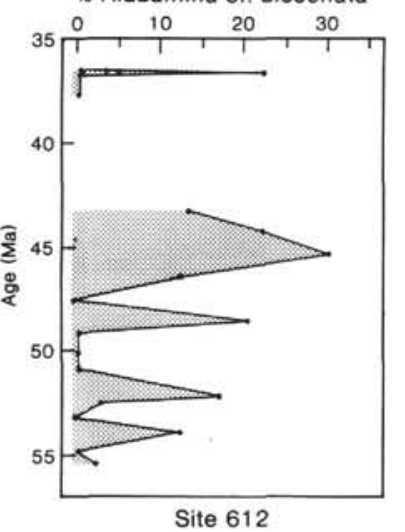

$\%$ Osangularia spp.

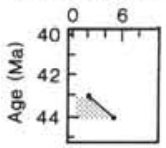

(

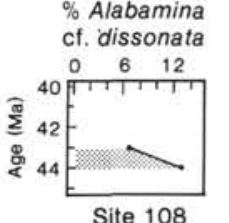

Site 108
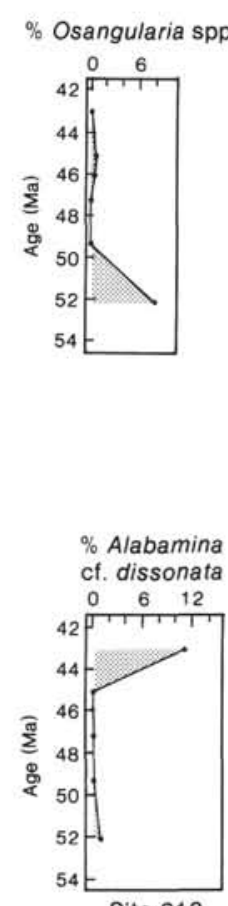

Site 613
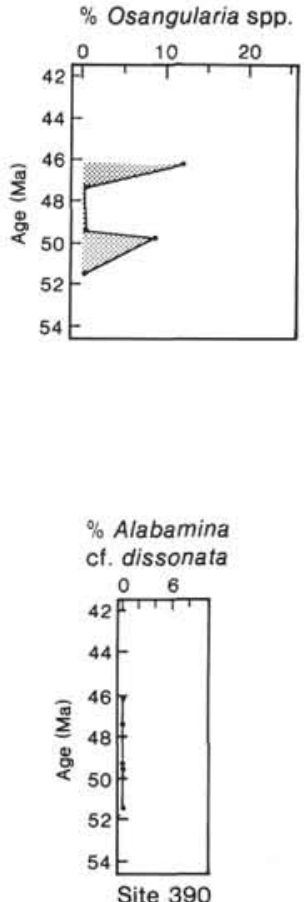

Figure 12. Layout as in Figure 6. A. Loadings on Factor I computed by analysis of New Jersey Transect (Sites $612,108,613$ ) and Site 390 (Tjalsma and Lohmann, 1983) census data of 48 taxa. B. Percent abundance of Lenticulina spp. along paleoslope. C. Percent abundance of Osangularia spp. along paleoslope. D. Percent abundance of Alabamina $\mathrm{cf}$. dissonata along paleoslope. 


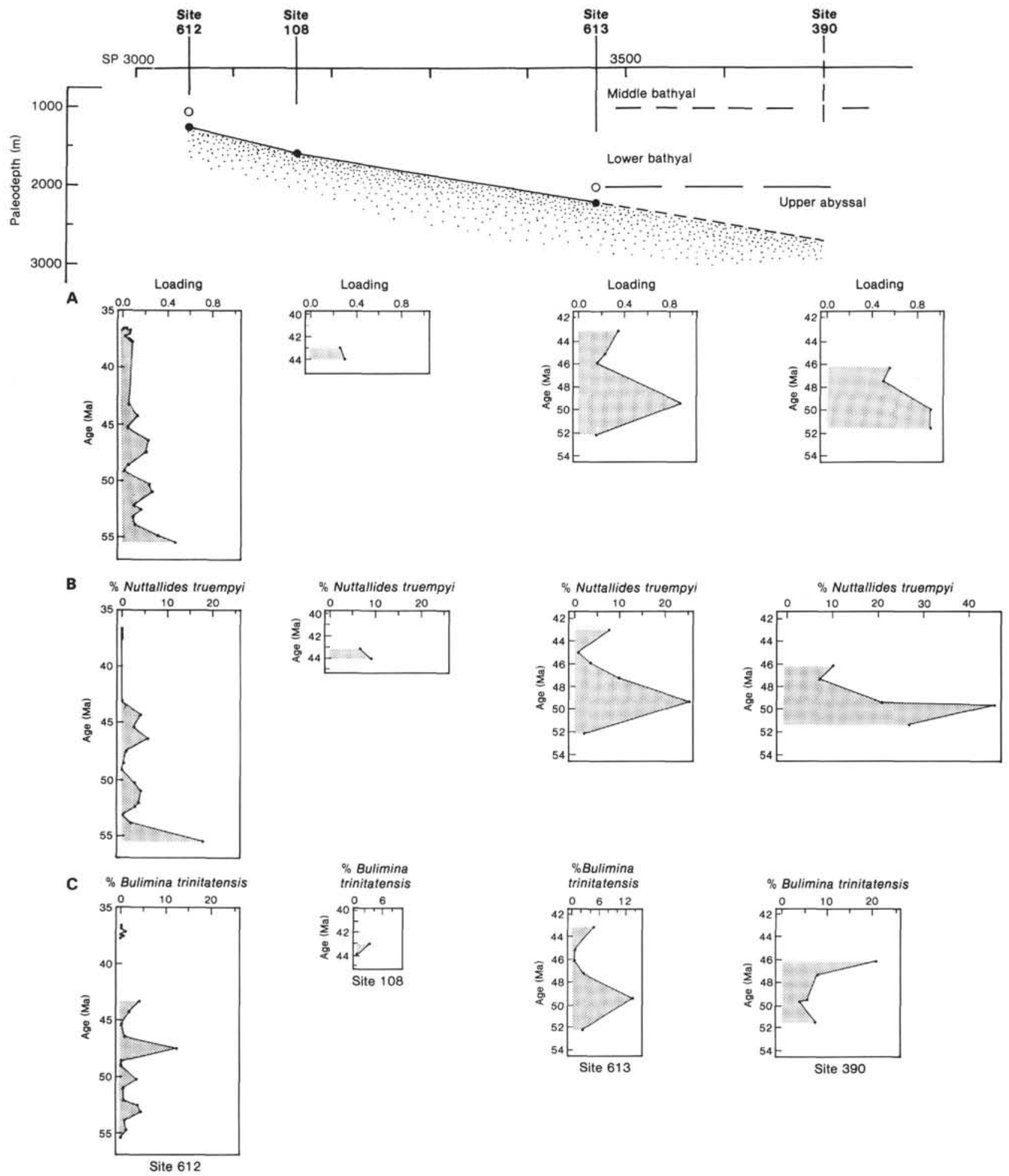

Figure 13. Layout as in Figure 6. A. Loadings on Factor III computed by analysis of New Jersey Transect (Sites 612, 108, 613) and Site 390 (Tjalsma and Lohmann, 1983) census data of 48 taxa. B. Percent abundance of Nuttallides truempyi along paleoslope. C. Percent abundance of Bulimina trinitatensis along paleoslope.

Cibicidoides havanensis (Cushman and Bermudez). Miller, 1983, p. 433 , pl. 2 , figs. $9,10$.

Cibicidoides havanensis (Cushman and Bermudez). Miller, Curry, et al., 1985 , p. 2, figs. 7-9.

Present at Site 612. Restricted to the lower Eocene at Site 613. Absent at Site 108 .

\section{Cibicidoides laurisae (Mallory)}

(Plate 7, Figs. 4-6)

Cibicides laurisae Mallory, 1959, p. 267, pl. 24, figs. 8a-c.

Cibicidoides aff. laurisae (Mallory). Tjalsma and Lohmann, 1983, p. 27 , pl. 17 , figs. $2 \mathrm{a}-\mathrm{c}$. 


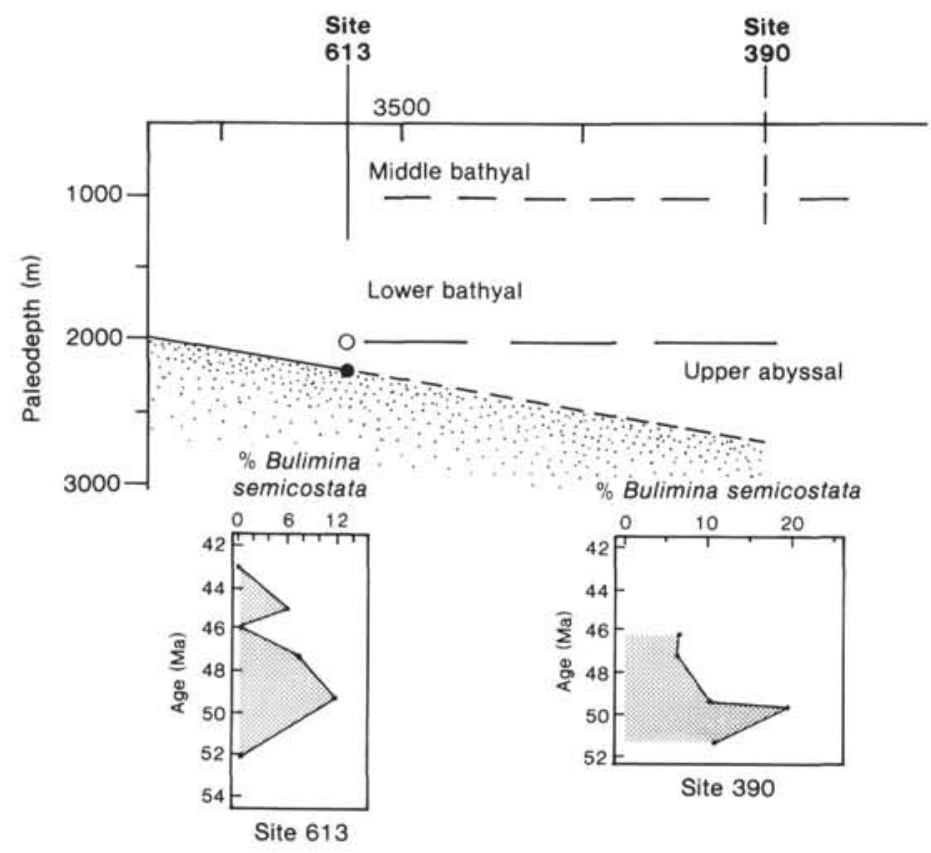

Figure 14. Percent abundance of Bulimina semicostata along paleoslope. This taxon was absent from Sites 612 and 108. Layout for Sites 613 and 390 as in Figure 6.

Cibicidoides aff. laurisae (Mallory). Miller, 1983, p. 433, pl. 2, figs. 3, 4. Cibicidoides laurisae (Mallory). Miller, Curry, et al., 1985, pl. 2, figs. 4-6.

Cibicidoides aff. laurisae (Mallory). Tjalsma, 1983, p. 742, pl. 8, figs. 2a-c.

We used a broad concept for this species, including both more convex specimens noted by Tjalsma and Lohmann (1983) and specimens with flatter umbilical sides. We include forms with and without umbilical infilling. Restricted to the upper middle to upper Eocene at Site 612. Common at Site 108. Absent at Site 613.

\section{Cibicidoides mundulus group}

(Plate 6, Figs. 1-3.)

Truncatulina mundula Brady, Parker, Jones, 1888, p. 228, pl. 45, figs. $25 \mathrm{a}-\mathrm{c}$.

Cibicides kullenbergi Parker, in Phleger, F. B., Parker F. L., and Peirson, J. F., 1953, p. 49, pl. 11, figs. 7, 8.

Cibicidoides ungerianus (d'Orbigny). Tjalsma and Lohmann, 1983, p. 28, pl. 18 , figs. 1a-c; pl. 21 , figs. 5,6 .

Cibicidoides ungerianus (d'Orbigny). Miller, 1983, p. 435, pl. 2, figs. $6,7$.

Cibicidoides ungerianus (d’Orbigny). Miller, Curry, et al., 1985, pl. 1, figs. 4-6.

Considerable confusion has surrounded the taxonomy of this group of abundant cibicidids. The genotype of Cibicidoides is C. mundulus, which is identical to and the senior synonym of Parker's species. Tjalsma (1983) noted the evolution of $C$. mundulus from a taxon he termed C. ungerianus. However, C. ungerianus (d'Orbigny) is a shallow-water Neogene form which is not related to the deep-sea taxon illustrated by many authors, including Tjalsma (1983), Tjalsma and Lohmann (1983), and Miller (1983). Therefore, another name for the Paleogene forms antecedent to $C$. mundulus is needed. Until a proper name is identified or designated, we assign both the antecedents and descendants to the C. mundulus group. Abundant at Site 612. Common at Site 613. Rare at Site 108 .

Cibicidoides sp. $\mathbf{P}$

(Plate 7, Figs. 1-3)

Rare at Site 612. Absent at Sites 108 and 613.
Cibicidoides subspiratus (Nuttall)

(Plate 7, Figs. 7-9)

Cibicides subspirata Nuttall, 1930, p. 292, pl. 25, figs. 9, 10, 14.

Cibicidoides subspiratus (Nuttall). Tjalsma and Lohmann, 1983, p. 28 , pl. 18, figs. 5a-c; pl. 22, figs. 5a, b.

This distinctive taxon is restricted in our material to Site 613. It has a stratigraphically useful range of Zones P10 to P12, in agreement with that of Tjalsma and Lohmann (1983), who noted a range of Zones P9 to P13.

\section{Cibicidoides tuxpamensis (Cole)}

(Plate 6, Figs. 7-9)

Cibicides tuxpamensis Cole, 1928, p. 219, pl. 1, figs. 2, 3; pl. 3, figs. $5,6$.

Cibicidoides tuxpamensis (Cole). Tjalsma and Lohmann, 1983, p. 28, pl. 18, figs. 3a-4c; pl. 22, figs. la-3c.

Cibicidoides tuxpamensis (Cole). Miller, Curry, et al., 1985, pl. 1, figs. $1-3$.

Common at Site 612. Abundant at Sites 108 and 613.

"Eggerella"sp.

"Eggerella"sp. Miller, 1983, p. 435.

This agglutinated form is triserial in the later stages, with earlier portions indeterminate. It has a loop-shaped aperture. Miller (1983) noted this taxon in the Eocene to Oligocene Bay of Biscay. Restricted to and common in the middle to upper Eocene at Site 612. Common in the middle Eocene at Site 613, with a single isolated occurrence in the lowermost Eocene. Present at Site 108.

\section{Gaudryina pyramidata Cushman}

(Plate 1, Figs. 9, 10)

Gaudryina laevigata Franke var. pyramidata Cushman, 1926b, p. 587, pl. 16 , figs. $8 \mathrm{a}$, b.

Gaudryina cf. pyramidata Cushman. Tjalsma and Lohmann, 1983, p. 31, pl. 8 , figs. $2 a$, b.

Restricted to the upper Eocene at Site 612. Absent at Sites 108 and 


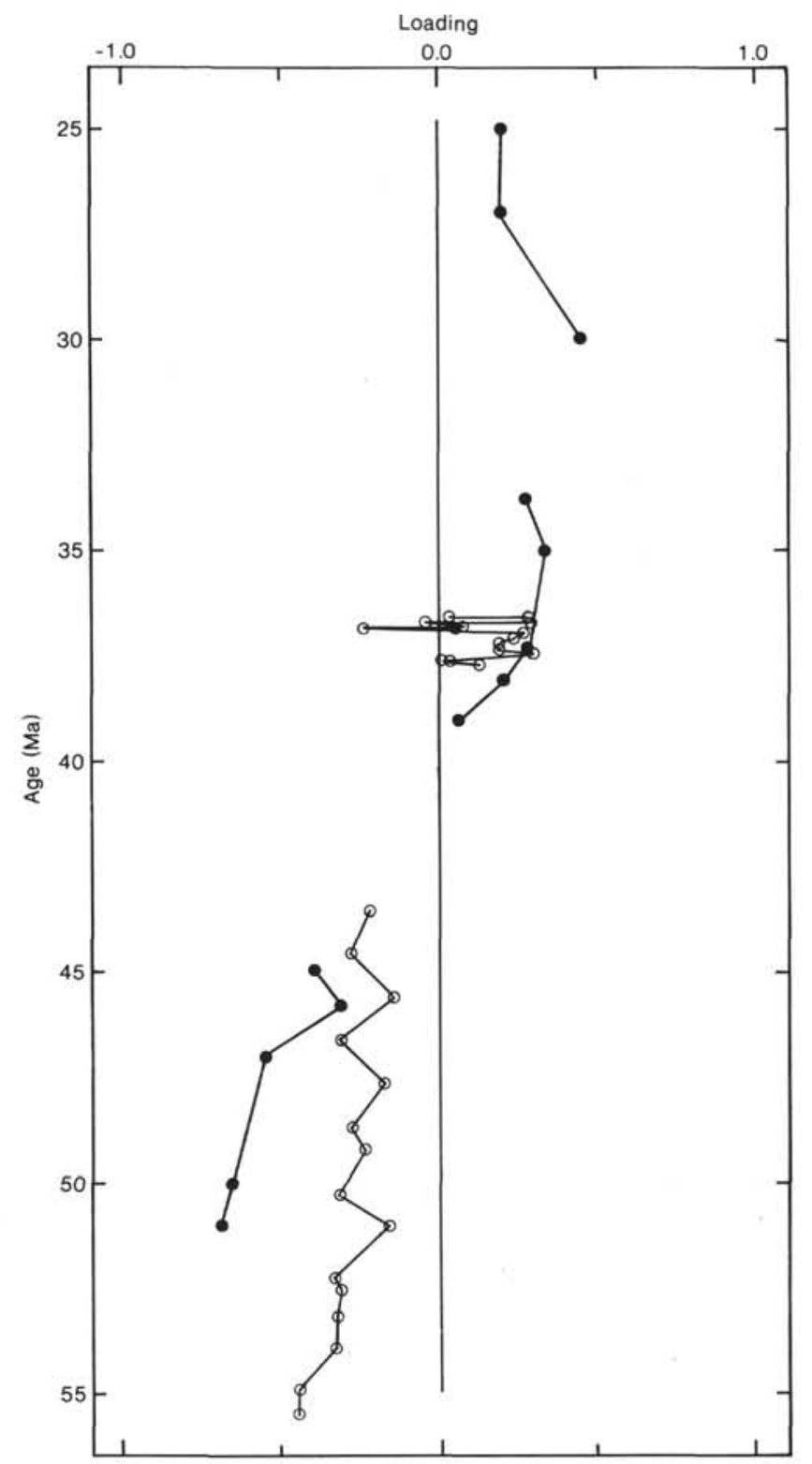

Figure 15. Loadings on Principal Component II, Site 548, Goban Spur. Closed circles are from Site 548; open circles are projections of Site 612 samples onto this vector. Vertical line drawn through 0.0 loadings.

\section{Gavelinella capitata (Guembel)}

(Plate 4, Figs. 4, 5, 6, 10, 11)

Rotalia capitata Guembel, 1868 , p. 653 , pl. 2, figs. $92 \mathrm{a}-\mathrm{c}$.

Anomalinoides capitatus (Guembel). Hagn, 1956, p. 176, pl. 16, figs. $15,16$.

Gavelinella capitata (Guembel). Tjalsma and Lohmann, 1983, p. 31, pl. 16 , figs. $4 a-5 b$.

Restricted to the lowermost Eocene at Site 612 and the lower Eocene at Site 613. Absent at Site 108. Combined with G. semicribrata in census (following Tjalsma and Lohmann, 1983).

We recognized a distinctive morphology, originally described by Nuttall (1930) as $A$. dorri var. aragonensis, which is restricted to the lower Eocene at Site 612 but absent from Site 613. Tjalsma and Lohmann (1983) included $A$. dorri and $A$. aragonensis as junior synonyms of $G$. capitata; we followed this and placed the highly ornamented specimens in G. capitata var. aragonensis (Plate 4, Figs. 4-6).

\section{Gavelinella micra (Bermudez)}

(Plate 4, Figs. 7-9)

Cibicides micrus Bermudez, 1949, p. 302, pl. 24, figs. 34-36.

Gavelinella micra (Bermudez). Tjalsma and Lohmann, 1983, p. 31, pl. 16 , figs. 7 a, b; pl. 20 , fig. 7 .

Gavelinella micra (Bermudez). Miller, 1983, p. 437, pl. 3, figs. 15-16.

Anomalinoides acuta (Plummer). Charletta, 1980, p. 64, pl. 4, figs.

16-18.

Abundant at Site 612. Common in the middle Eocene at Site 613; absent in the lower Eocene. Common at Site 108. Charletta (1980) noted $A$. acuta throughout the Eocene of the New Jersey coastal plain.

\section{Gavelinella semicribrata (Beckmann)}

Anomalina pompilioides Galloway and Heminway var. semicribrata Beckmann, 1953, p. 400, pl. 27, fig. 3; text-figs. 24, 25.

Gavelinella semicribrata (Beckmann). Tjalsma and Lohmann, 1983, p. 31 , pl. 16 , figs. $6 a$, b.

Gavelinella semicribrata (Beckmann). Miller, 1983, p. 437, pl. 3, figs. 2,5 .

Combined with G. capitata in census (following Tjalsma and Lohmann, 1983). Restricted to the middle and lowermost Eocene at Site 612. Present in middle Eocene Zones P10 to P11 at Site 613. Common at Site 108.

\section{Globocassidulina subglobosa (Brady)}

Cassidulina subglobosa Brady, 1881, p. 60 (type reference).

Cassidulina subglobosa (Brady) Brady, 1884, p. 430, pl. 54, figs. 17a-c (type figure).

Globocassidulina subglobosa (Brady). Tjalsma and Lohmann, 1983, p. 31 , pl. 16 , fig. 9 .

Present throughout the Site 612 section. Restricted to the middle Eocene at Site 613. Absent at Site 108.

\section{Hanzawaia ammophila (Guembel)}

(Plate 5, Figs. 7-9)

Rotalia ammophila Guembel, 1868, p. 652, pl. 2, figs. 90a, b. Cibicides cushmani Nuttall, 1930, p. 291, pl. 25, figs. 3, 5, 6 .

Hanzawaia cushmani (Nuttall). Tjalsma and Lohmann, 1983, p. 32, pl. 17, figs. 1a-c.

Hanzawaia cushmani (Nuttall). Miller, 1983, p. 437, pl. 1, fig. 12.

Planulina? ammophila (Guembel). Charletta, 1980, p. 66, pl. 5, figs. 7-9.

Hagn (1956) placed $H$. cushmani and $H$. ammophila into synonomy. Tjalsma and Lohmann (1983) examined one paratype, provided by Hagn to the U.S. National Museum, and suggested that the latter was more rapidly uncoiling. Berggren (personal communication, 1985) examined type material provided by Hagn and concluded that $H$. ammophila was the senior synonym. Charletta (1980) reported this taxon from the middle to upper Eocene of the COST B-2 well. Abundant at Site 612 (sporadically). Restricted to Zones P11 to P12 at Site 613. Abundant at Site 108.

\section{Karreriella chapapotensis (Cole)}

(Plate 1, Figs. 3, 4)

Textularia chapapotensis Cole, 1928, p. 206, pl. 33, fig. 9. Karreriella chapapotensis (Cole). Tjalsma and Lohmann, 1983, p. 32, pl. 9 , figs. $2 \mathrm{a}$, b.

Common in the middle to upper Eocene at Site 612 and in the middle Eocene at Sites 108 and 613. We noted $K$. chapapotensis var. monumentensis Mallory in these sections.

\section{Karreriella cubensis Cushman and Bermudez}

Karreriella cubensis Cushman and Bermudez, 1937, p. 4, pl. 1, figs. $18,19$.

Karreriella cf. cubensis Cushman and Bermudez. Tjalsma and Lohmann, 1983, p. 33, pl. 9, figs. 4a, b.

We did not see an initial triserial portion; but we retained Tjalsma and Lohmann's (1983) taxonomy. This form actually may be assignable to Siphotextularia sp. Rare in the middle to upper Eocene at Site 612. Possible occurrences at Site 613. Absent at Site 108. 

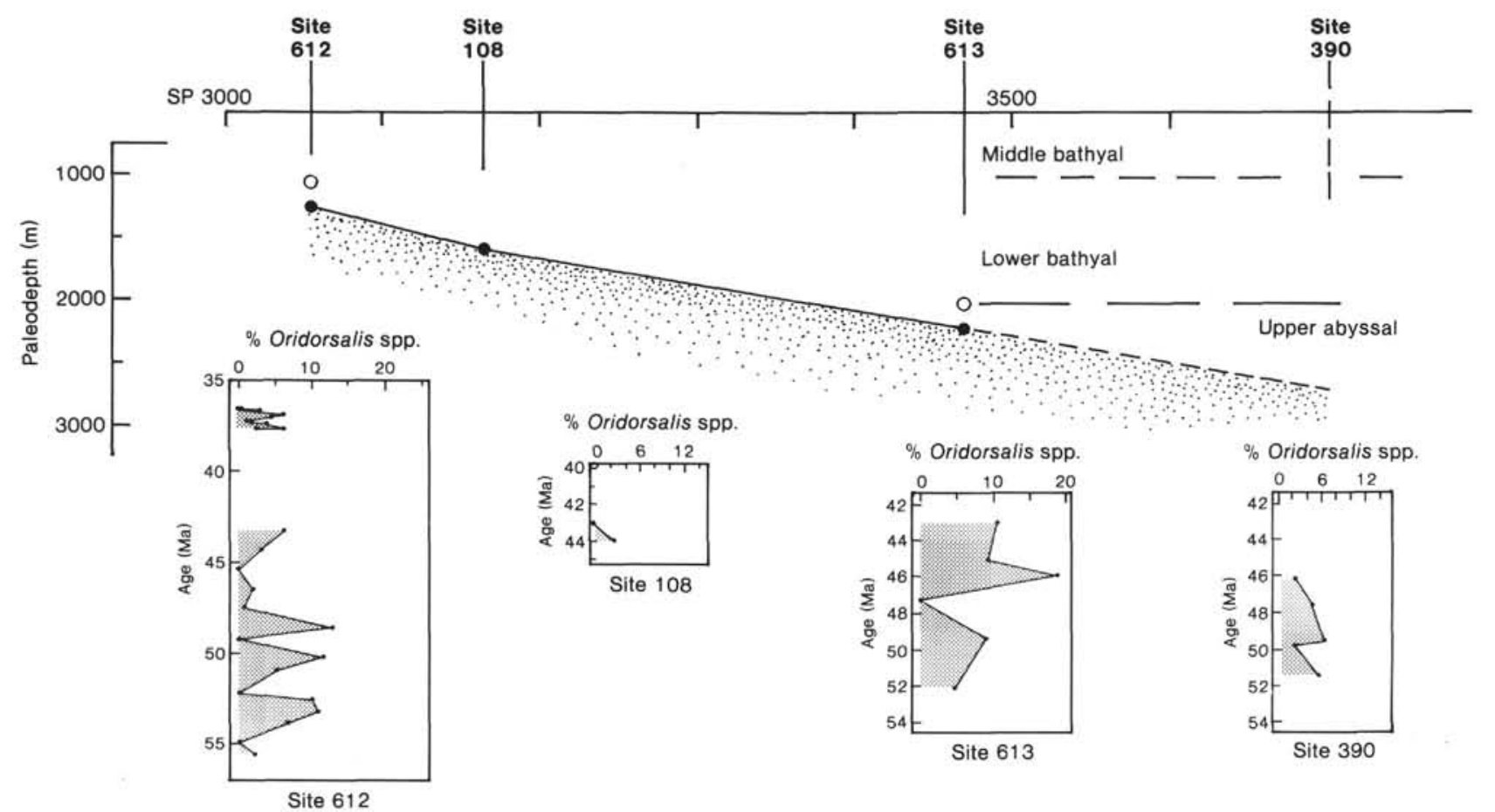

Figure 16. Percent abundance of Oridorsalis spp. along paleoslope. Layout as in Figure 6.

\section{Karreriella subglabra (Guembel)}

(Plate 1, Figs. 1, 2)

Gaudryina subglabra Guembel, 1868, p. 602 , pl. 1, figs. $4 a$, b.

Gaudryina bradyi Cushman, 1911, p. 67, fig. 107.

Karreriella bradyi (Cushman). Cushman, 1937, p. 135, pl. 16, figs. 611.

Karreriella bradyi (Cushman). Barker, 1960, pl. 46, figs. 1-4.

Karreriella subglabra (Guembel). Tjalsma and Lohmann, 1983, p. 34, pl. 9, figs. 1a, b.

Miller (1983) suggested that $K$. subglabra might be conspecific with $K$. bradyi. If so, then the senior synonym is $K$. subglabra. Rare at Sites 108 and 612. Common at Site 613.

\section{Nonion havanense Cushman and Bermudez} (Plate 2, Figs. 13, 14)

Nonion havanense Cushman and Bermudez, 1937, p. 19, pl. 2, figs. $13,14$.

Nonion havanense Cushman and Bermudez. Tjalsma and Lohmann, 1983, p. 17 , pl. 7, figs. 6 a, b.

Common to abundant at all three sites.

\section{Nonionellina sp}

(Plate 2, Figs. 15, 16)

Common in the middle and upper Eocene at Site 612. Absent from Sites 108 and 613. Differs from Nonionella in lacking a chamber extension over the umbilicus and from Pseudononion in being almost planispiral in the final stage.

\section{Nuttallides truempyi (Nuttall) \\ (Plate 4, Figs. 1-3)}

Eponides truempyi Nuttall, 1930, p. 287, pl. 24, figs. 9, 13, 14. Nuttallides truempyi (Nuttall). Tjalsma and Lohmann, 1983, p. 17, pl. 6 , figs. $4 a$, b; pl. 17 , figs. $4 a-5 b$, pl. 21 , figs. $1 \mathrm{a}-4 \mathrm{c}$. Nuttallides truempyi (Nuttall). Miller, 1983, p. 439, pl. 1, figs. 4-6.

Abundant in the lower to middle Eocene at Sites 612, 108, and 613; absent in the upper Eocene at Site 612. Charletta (1980) reported that this taxon is restricted to lower Eocene deposits on the New Jersey shelf (COST B-2 well).

\section{Planulina costata (Hantken)}

(Plate 5, Figs. 1-3)

Truncatulina costata Hantken, 1875, p. 73, pl. 9, figs. 2a-c.

Planulina cocoaensis Cushman. Charletta, 1980, p. 58, pl. 2, figs.

$10-12$.

This distinct, flattened, planulinid is restricted to the upper Eocene of Site 612, with an isolated possible occurrence in the middle Eocene of that site. Absent at Sites 108 and 613. In the New Jersey coastal plain, Charletta reported sporadic occurrences of this taxon in middle and upper Eocene deposits, including the COST B-2 well.

\section{Planulina cf. renzi Cushman and Stainforth} (Plate 5, Figs. 4-6)

Planulina renzi Cushman and Stainforth, 1945, p. 72, pl. 15, figs la-c. Planulina renzi Cushman and Stainforth. Tjalsma, 1983, p. 743, pl. 3 ,

fig. 4 ; pl. 6, figs. $6,7$.

Restricted to the upper Eocene at Site 612, with an isolated occurrence in the uppermost middle Eocene. Absent from Sites 108 and 613. Elsewhere, the first occurrence of this species is generally in the Oligocene. In general, our specimens are not typical, but have an enlarged umbonal boss with rapidly increasing chambers. The specimen illustrated here is closer in morphology to typical $P$. renzi.

\section{Plectofrondicularia spp.}

Restricted to the upper Eocene at Site 612, except for a single isolated occurrence in the middle Eocene. Absent from Site 613.

\section{Pullenia eocenica Cushman and Siegfus (Plate 3, Fig. 7)}

Pullenia eocenica Cushman and Siegfus, 1939, p. 31, pl. 7, figs. 1a, b. Pullenia eocenica Cushman and Siegfus. Tjalsma and Lohmann, 1983, p. 36 , pl. 16 , fig. 1 .

Pullenia eocenica Cushman and Siegfus. Miller, 1983, p. 439, pl. 4, fig. 11 .

We included forms assignable to $P$. bulloides (d'Orbigny). Abundant at all sites, particularly in the upper Eocene of Site 612. Tjalsma and Lohmann (1983) reported a first appearance in Zone P9, with a questionable appearance in Zone P6a. At Site 612, this taxon occurs 


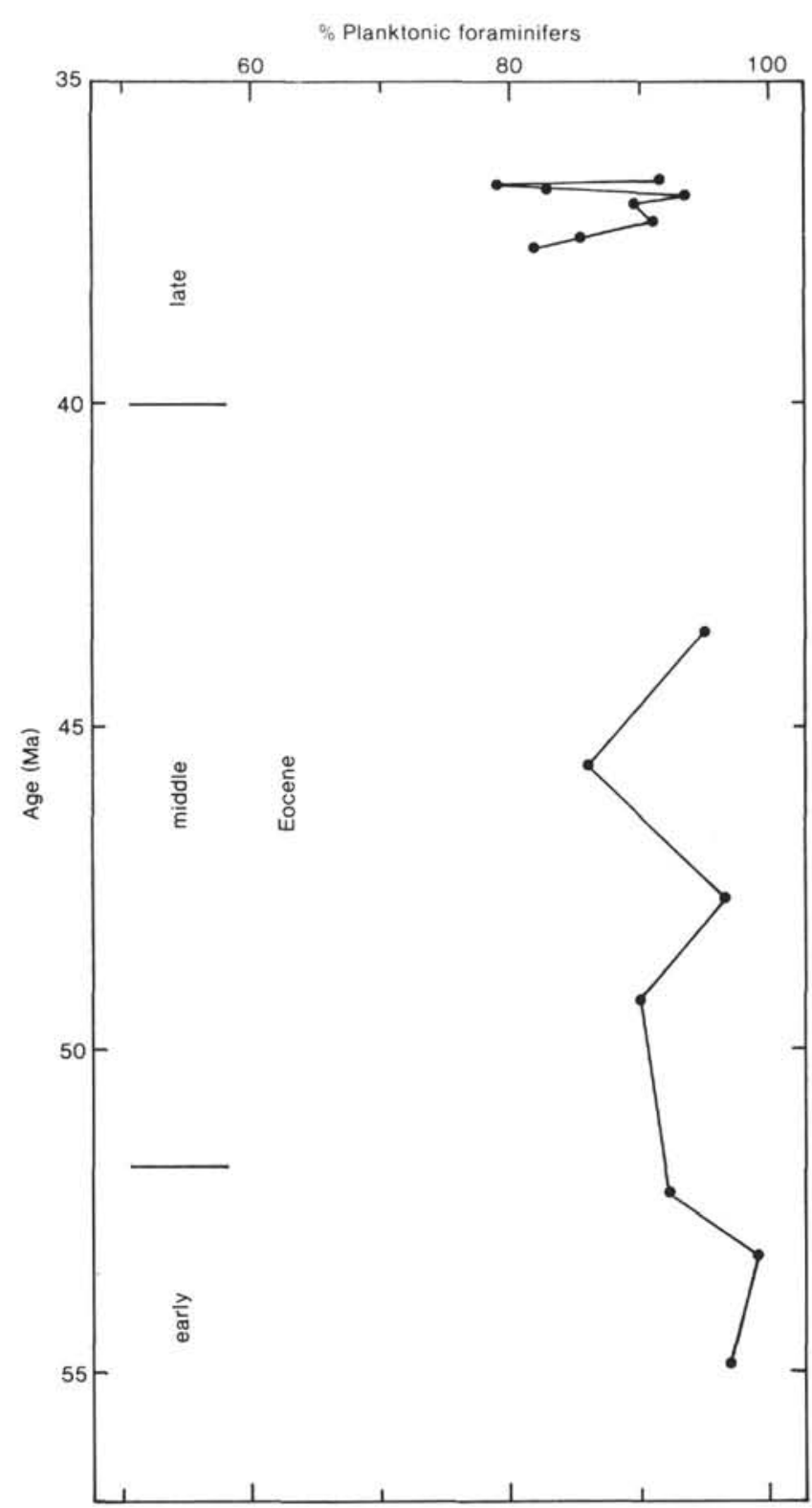

Figure 17. Planktonic foraminifers as percentage of total foraminifers counted, Site 612.

in the next to lowest sample examined (Zone P7). At Site 613 it occurs throughout the section studied.

\section{Pullenia quinqueloba (Reuss) (Plate 3, Figs. 8, 9)}

Nonionina quinqueloba Reuss, 1851, p. 71, pl. 5, figs. 31a, b. Pullenia quinqueloba (Reuss). Tjalsma and Lohmann, 1983, p. 36, pl. 16, fig. 2.

Pullenia quinqueloba (Reuss). Miller, 1983, pl. 4, figs. 9, 10.

Abundant at Site 612. Common in the middle Eocene at Sites 108 and 613 .

\section{Rhzehakina epigona (Rzehak) \\ (Plate 1, Figs. 15, 16)}

Silicina epigona Rzehak, 1895 , p. 214 , pl. 6, figs. 1a-c.

Rhzehakina epigona (Rzehak), Gradstein and Berggren, 1981, p. 248, pl. 5, fig. 1.

Miller et al. (1982) noted a range into lower Eocene of the Labrador Shelf. Restricted to the lower Eocene of Site 612. Present in the lowermost middle Eocene at Site 613. Absent at Site 108.
Sigmoilopsis sp.

(Plate 1, Figs. 11, 12)

Similar to $S$. schlumbergeri, but more compressed. Present in every sample from the uppermost middle to upper Eocene at Site 612, with a single isolated occurrence in the lowermost middle Eocene. Absent at Sites 108 and 613.

\section{Siphonina sp.}

(Plate 5, Figs. 10-12)

In our material, this unusual siphoninid has no pronounced siphon. This may be an artifact of preservation, or else this species may be assignable to Pulsiphonina. Abundant and restricted to the upper lower Eocene (Zone P9) and the sample immediately above the middle/lower Eocene unconformity at Site 612. Absent at Sites 108 and 613.

\section{Spiroplectammina spectabilis Grzybowski (Plate 1, Figs. 5, 6)}

Spiroplecta spectabilis Grzybowski, 1898, p. 293, pl. 12, fig. 12.

Spiroplectoides clotho (Grzybowski). Cushman and Jarvis, 1928, p. 101 , pl. 14 , figs. 13,14 .

Spiroplectammina grzybowskii Frizzell, 1943, p. 339, pl. 55, figs. 12a, b, 13.

Spiroplectammina grzybowskii Frizzell. Cushman and Renz, 1946, p. 20 , pl. 5, figs. 34-38.

Spiroplectammina spectabilis (Grzybowski). Tjalsma and Lohmann, 1983 , p. 20 , pl. 1, fig. 11 , pl. 9 , figs. $8-10$.

Spiroplectammina spectabilis (Grzybowski). Miller et al., 1982, p. 22,

pl. 2, figs. 2,3 .

Found in the upper lower Eocene to upper Eocene at Site 612 and middle Eocene of Site 613. Does not occur in Oligocene samples at Site 612. Absent at Site 108.

\section{Spirosigmoilinella compressa Matsunaga}

(Plate 1, Figs. 13, 14)

Spirosigmoilinella compressa Matsunaga, 1955, p. 50, figs. 1, 2. Spirosigmoilinella compressa Matsunaga. Miller et al., 1982, p. 20, pl. 2, fig. 5 .

Miller et al. (1982) reported this taxon from the upper middle to upper Eocene of the southern Labrador Sea and the middle to upper Eocene of the North Sea. The forms noted here are acid-soluble, however, unlike the acid-insoluble specimens noted by Miller et al. (1982). Restricted to the upper Eocene at Site 612 and the middle Eocene at Site 613. Absent at Site 108.

\section{Stilostomella aculeata (Cushman and Renz)}

Ellipsonodosaria nuttalli Cushman and Jarvis var. aculeata Cushman, and Renz, 1948, p. 32, pl. 6, fig. 10.

Stilostomella aculeata (Cushman and Renz). Tjalsma and Lohmann, 1983 , p. 36, pl. 14, fig. 12.

Stilostomella aculeata (Cushman and Renz). Miller, 1983, p. 439, pl. 4, fig. 1 .

We included in this taxon rare specimens with basal spines which lacked the ring of spines on the lower part of the chamber and which may actually belong in E. nuttalli. Common to abundant at Sites 108 and 612. Rare at Site 613.

\section{Stilostomella curvatura (Cushman)}

(Plate 2, Fig. 3)

Ellipsonodosaria curvatura Cushman, 1939, p. 71, pl. 12, fig. 6 .

Stilostomella curvatura (Cushman). Tjalsma, 1983, p. 743, pl. 1, figs. $7-11$.

Common at Sites 108 and 612. Rare at Site 613.

\section{Stilostomella gracillima (Cushman and Jarvis)}

Ellipsonodosaria nuttalli var. gracillima Cushman and Jarvis, 1934, p. 72 , pl. 10 , fig. 7 .

Stilostomella gracillima (Cushman and Jarvis). Tjalsma and Lohmann, 1983 , p. 36 , pl. 14, figs. 13-15.

Stilostomella gracillima (Cushman and Jarvis). Miller, 1983, p. 439, pl. 4 , fig. 3 . 
Abundant from the upper lower to upper Eocene at Site 612. Abundant in the middle Eocene at Site 613. Absent at Site 108.

\section{Stilostomella subspinosa (Cushman)}

Ellipsonodosaria subspinosa Cushman, 1943, p. 92, pl. 16, figs. 6-7b. Stilostomella subspinosa (Cushman). Tjalsma and Lohmann, 1983, p. 36 , pl. 14, figs. 16,17 .

Stilostomella subspinosa (Cushman). Miller, 1983, p. 440. pl. 4, fig. 2. Abundant in the middle and upper Eocene at Site 612 and in the middle Eocene at Site 613. Absent at Site 108.

\section{Trifarina danvillensis (Howe and Wallace)}

Uvigerina danvillensis Howe and Wallace, 1932, p. 62 , pl. 12, fig. 5 . Trifarina danvillensis (Howe and Wallace). Tjalsma, 1983, pl. 2, figs. 6,7 .

Restricted to the upper Eocene and the Oligocene at Site 612. Single occurrence in the middle Eocene at Site 613. Absent at Site 108. Tjalsma (1983) found it restricted to the Oligocene of Site 516.

\section{Trifarina wilcoxensis (Cushman and Ponton)} (Plate 2, Fig. 5, 6)

Pseudouvigerina wilcoxensis Cushman and Ponton, 1932, p. 66, pl. 8, fig. 18.

Trifarina wilcoxensis (Cushman and Ponton). Charletta, 1980, p. 62 , pl. 4 , fig. 5 .

Rare to abundant in the upper lower to middle Eocene at Site 612 . Absent at Sites 108 and 613.

\section{Turrilina robertsi (Howe and Ellis)}

Bulimina robertsi Howe and Ellis, 1939, p. 63, pl. 8, figs. 32, 33. Turrilina robertsi (Howe and Ellis). Tjalsma and Lohmann, 1983, p. 37 , pl. 14 , fig. 5 .

Turrilina robertsi (Howe and Ellis). Miller, 1983, p. 440, pl. 3, fig. 9. Turritilina sp. (sic), Charletta, 1980, p. 62, pl. 3, figs. 11-13.

Restricted to the lower and middle Eocene at Site 612. Common at Site 108. Absent from Site 613 .

\section{Uvigerina basicordata Cushman and Renz}

Uvigerina gallowayi Cushman var. basicordata Cushman and Renz, 1941 , p. 21 , pl. 3 , figs. 18 a, b.

Occurs in high abundance in the two uppermost (Oligocene) samples at Site 612. Absent at Sites 108 and 613. The first occurrence of this taxa at the base of the Oligocene may be stratigraphically useful.

\section{Uvigerina hispida Schwager}

(Plate 2, Fig. 4)

Uvigerina hispida Schwager, 1866, p. 249, pl. 7, fig. 95.

Uvigerina chirana Cushman and Stone, 1947, p. 17, pl. 2, fig. 25.

Uvigerina chirana Cushman and Stone. Tjalsma, 1983, pl. 2, fig. 11.

Common in the upper middle to upper Eocene at Site 612. Isolated occurrence in the middle Eocene at Site 613. Absent at Site 108.

\section{Uvigerina rippensis Cole}

Uvigerina rippensis Cole, 1927, p. 11, pl. 2, fig. 16 .

Uvigerina rippensis Cole. Tjalsma and Lohmann, 1983, p. 38, pl. 14, figs. 6,7 .

Restricted to the upper middle to upper Eocene at Site 612; single occurrence at Site 613. Common at Site 108.

\section{Vaginulina decorata Reuss}

$$
\text { (Plate 2, figs. 7, 8) }
$$

Cristellaria decorata Reuss, 1855, p. 269, pl. 8, fig. 16; pl. 9, figs. 1, 2. Rare at Site 612. Absent at Sites 108 and 613.

\section{Vulvulina spinosa Cushman}

(Plate 1, Figs. 7, 8)

Vulvulina spinosa Cushman, 1927b, p. 111, pl. 23, fig. 1.

Vulvulina spinosa Cushman. Tjalsma and Lohmann, 1983, p. 38, pl. 10 , figs. $4 a-5 b$
Common to abundant in the lower to middle Eocene at Site 612; several occurrences into the Oligocene. Common to abundant in the middle Eocene at Sites 108 and 613.

Other taxa not discussed: Clavulina sp., Dentalina/Vaginulina spp., Globobulimina spp., Martinotiella sp., Melonis spp., Plectina spp., Tritaxia sp.

\section{ACKNOWLEDGMENTS}

We thank W. A. Berggren, G. S. Mountain, R. K. Olsson, A. Palmer, C. W. Poag, and R. C. Tjalsma for reviewing the manuscript; R. C. Tjalsma for discussions and for providing samples from Site 390; the shipboard party for discussions; M. Hart and C. W. Poag for providing planktonic biostratigraphic data; $\mathrm{S}$. Hambos for technical assistance; A. C. Charletta for providing comparative material; and A. D. Chave for software. We especially thank M. Steckler for providing unpublished backstripped estimates and D. Grieg of Chevron for producing the scanning electron microscope micrographs. Samples were provided by DSDP. This research was funded by NSF Grant OCE 83 10086 and OCE 8500859 , a grant from the Arco foundation, and a consortium of oil companies (Arco, BP, Chevron, Elf, Exxon, Gulf, Mobil, Phillips, Shell, Shell International, Phillips, Texaco, and Union). This is Lamont-Doherty Geological Observatory Contribution number 4021 .

\section{REFERENCES}

Aubry, M. P., 1985. Northwestern European Paleogene magnetostratigraphy, biostratigraphy, and paleogeography, calcareous nannofossil evidence. Geology, 13(3): 161-224.

Bandy, O. L., 1953a. Ecology and paleoecology of some California foraminiferal evidence of subsidence rates in the Ventura Basin. In Curtis, D. M., (Ed.), Depositional Environments and Paleoecology-Foraminiferal Paleoecology. Soc. Econ. Paleontol. Mineral., Reprint Series, 2:35-38.

1953b. The geologic significance of coiling ratios in the foraminifer Globigerina pachyderma (Ehrenberg). In Curtis, D. M. (Ed.), Depositional Environments and Paleoecology-Foraminiferal Paleoecology. Soc. Econ. Paleontol. Mineral., Reprint Series, 2:70-80.

Barker, P. F., 1983. Tectonic evolution and subsidence history of the Rio Grande Rise. In Barker, P. F., Carlson, R. L., Johnson, D. A., et al., Init. Repts. DSDP, 72: Washington (U.S. Govt. Printing Office), 953-976.

Barker, R. W., 1960. Taxonomic notes on the species figured by H. B. Brady in his "Report on the foraminifera dredged by H.M.S. Challenger during the years 1873-1876." Spec. Publ. Soc. Econ. Paleontol. Mineral., 9.

Beckmann, J. P., 1953. Die Formaminiferen der Oceanic Formation (Eozän-Oligozän) von Barbados, Kl. Antillen. Eclogae. Geol. Helv., 46(2):400.

Berger, W. H., and Winterer, E. L., 1974. Plate stratigraphy and the fluctuating carbonate line. In Hsü, K. J., and Jenkyns, H. C. (Eds.), Pelagic Sediments on Land and Under the Sea. Spec. Publ. Int. Assoc. Sediment., 1:11-48.

Berggren, W. A., 1972. Cenozoic biostratigraphy and paleobiogeography of the North Atlantic. In Laughton, A. S., Berggren, W. A., Init. Repts. DSDP, 12: Washington (U.S. Govt. Printing Office), 965-1001.

1978. Marine micropaleontology -an introduction. In Haq, B. U., and Boersma, A. (Eds.), Introduction to Marine Micropaleontology: New York, (Elsevier) pp. 1-17.

Berggren, W. A., and Aubert, J., 1983. Paleogene benthic foraminiferal biostratigraphy and paleobathymetry of the central Coast Ranges of California. In Brabb, E. E. (Ed.), Studies in Tertiary Stratigraphy of the California Coast Ranges. Geol. Surv. Prof. Pap. U.S., 1213:4-21.

Berggren, W. A., and Aubry, M.-P., 1984. Rb-Sr glauconite isochron of the Eocene Castle Hayne Limestone, North Carolina: Further discussion. Geol. Soc. Am. Bull., 95:364-370.

Berggren, W. A., Kent, D. V., and Flynn, J., 1985. Paleogene geochronology and chronostratigraphy. In Snelling, N. J. (Ed.), Geochronology and the Geologic Time Scale. Spec. Publ.-Geol. Soc. London, pp. 141-195. 
Bermudez, P. J., 1949. Tertiary smaller foraminifera of the Dominican Republic. Spec. Publ. Cushman Lab. Foram. Res., 25:302.

Blow, W. H., 1979. The Cainozoic Globigerinida: London (E. J. Brill).

Brady, H. B., 1881. Notes on some of the reticularian Rhizopoda of the "Challenger" Expedition; Part III. Q. J. Microsc. Sci., 21:60. 1884. Report on the foraminifera dredged by the HMS Challenger, during the years 1873-1876. Rept. Voy. HMS Challenger, Zool., 9.

Brady, H. B., Parker, W. K., and Jones, T. R., 1888. On some foraminifera from the Abrohlos Bank. Trans. Zool. Soc. London, 12 (Pt. 7, No. 1):228.

Bremer, M. L., and Lohmann, G. P., 1982. Evidence for primary control of the distribution of certain Atlantic Ocean benthonic foraminifera by degree of carbonate saturation. Deep-Sea Res., 29: 987-998.

Charletta, A. C., 1980. Eocene benthic foraminiferal paleoecology and paleobathymetry of the New Jersey continental margin [unpubl. Ph.D. thesis]. Rutgers, The State University of New Jersey, New Brunswick, N. J.

Cole, W. S., 1927. A foraminiferal fauna from the Guayabal Formation in Mexico. Am. Paleontol. Bull., 14(51):11. 1928. A foraminiferal fauna from the Chapapote Formation in Mexico. Am. Paleontol. Bull., 14(53): 219.

Corliss, B. H., 1979. Quaternary Antarctic bottom water history: Benthonic foraminiferal evidence from the southeast Indian Ocean. Quat. Res., 12:271-289.

Corliss, B. H., and Keigwin, L. D., Jr., in press. Eocene-Oligocene paleoceanography. In Hsü, K. (Ed.), South Atlantic Paleoceanography. Am. Geophys. Union.

Coryell, H. N., and Rivero, F. C., 1940. A Miocene microfauna of Haiti. J. Paleontol., 14:324-344.

Cushman, J. A., 1911. A monograph of the foraminifera of the North Pacific Ocean; Part II-Textulariidae. Bull. U.S. Nat. Mus., 71:54. 1925. New foraminifera from the upper Eocene of Mexico. Contr. Cushman Lab. Foram. Res., 1(3):6

1926a. Some fossil Bolivinas from Mexico. Contr. Cushman Lab. Foram. Res., 1(4):83.

, 1926b. The foraminifera of the Velasco Shale of the Tampico Embayment. Am. Assoc. Petrol. Geol., 10 (Pt. 1, No. 6):587. 1927a. New and interesting foraminifera from Mexico and Texas. Contr. Cushman Lab. Foram. Res., 3 (Pt. 2, No. 41):111. , 1927b. Some characteristic Mexican fossil foraminifera. $J$. Paleontol., 1:161.

1937. A monograph of the foraminiferal family Valvulinidae. Spec. Publ. Cushman Lab. Foram. Res., 8.

1939. Eocene foraminifera from submarine cores off the eastern coast of North America. Contr. Cushman Lab. Foram. Res., 15(3):71.

1943. Some new foraminifera from the Tertiary of the Island of St. Croix. Contr. Cushman Lab. Foram. Res., 19:92.

Cushman, J. A., and Bermudez, P. J., 1936. New genera and species of foraminifera from the Eocene of Cuba. Contr. Cushman Lab. Foram. Res., 12(2):36.

1937. Further new species of foraminifera from the Eocene of Cuba. Contr. Cushman Lab. Foram. Res., 13(1):19,28.

Cushman, J. A., and Jarvis, P. W., 1928. Cretaceous foraminifera from Trinidad. Contr. Cushman Lab. Foram. Res., 4:101.

1934. Some interesting new uniserial foraminifera from Trinidad. Contr. Cushman Lab. Foram. Res., 10(3):72.

1936. Cretaceous foraminifera from Trinidad. Contr. Cushman Lab. Foram. Res., 4(4):66.

Cushman, J. A., and Parker, F. L., 1936. Some American Eocene Buliminas. Contr. Cushman Lab. Foram. Res., 12(2):39,42.

1939. Bulimina macilenta Cushman and Parker, a new name. Contr. Cushman Lab. Foram. Res., 15(4):93.

Cushman, J. A., and Ponton, G. M., 1932. An Eocene foraminiferal fauna of Wilcox Age from Alabama. Contr. Cushman Lab. Foram. Res., 8(3):66.

Cushman, J. A., and Renz, H. H., 1941. New Oligocene-Miocene foraminifera from Venezuela. Contr. Cushman Lab. Foram. Res. $17: 21$

1946. The foraminiferal fauna of the Lizard Springs Formation of Trinidad, West Indies. Spec. Publ. Cushman Lab. Foram. Res., 18:20.
1948. Eocene foraminifera of the Navet and Hospital Hill formations of Trinidad, B.W.I. Spec. Publ. Cushman Lab. Foram. Res., 24:32,35.

Cushman, J. A., and Siegfus, S. S., 1939. Some new and interesting foraminifera from the Kreyenhagen shale of California. Contr. Cushman Lab. Foram. Res., 15(2):31.

Cushman, J. A., and Stainforth, R. M., 1945. The foraminifera of the Cipero marl formation of Trinidad, British West Indies. Spec. Publ. Cushman Lab. Foram. Res., 14:71,72.

Cushman, J. A., and Stone, B., 1947. An Eocene foraminiferal fauna from the Chira shale of Peru. Spec. Publ. Contr. Cushman Lab. Foram. Res., 20:17.

Frizzell, D. L., 1943. Upper Cretaceous foraminifera from northwestern Peru. J. Paleontol. 17:331-353.

Gradstein, F. M., and Berggren, W. A., 1981. Flysch-type agglutinated foraminifera and the Maestrichtian to Paleogene history of the Labrador and North seas. Mar. Micropaleontol., 6:211-268.

Grimsdale, T. F., and van Morkhoven, F. P. C. M. 1955. The ratio between pelagic and benthonic foraminifera as a means of estimating depth of deposition of sedimentary rocks. Proc. Fourth World Pet. Congr. Pap. 4, pp. 473-491.

Grzybowski, J., 1898. Otwornice, poktadow naftonosnych okolicy Krosna. Akad. Umiej. Krakowie, Vol. 33 (Ser. 2, Vol. 13):293.

Guembel, C. W., 1868. Bietrage zur Foraminiferenfauna der nordalnen Eozängebilde. K. Bayer. Akad., 10(2):602, 652, 653.

Hagn, H., 1956. Geologische und paläontologische Untersuchungen im Teritiär des Monte Brione und seiner Umgebung (Gardasee, Ober-Italien). Palaeontographica, Abt. A., 107:67-210.

Hantken, M., 1875. Die fauna der Clavulinaszaboi-Schichten; Theil I-Foraminiferen. K. Ungar. Geol. Anstl., 4(1):73.

Heezen, B. C., Tharp, M., and Ewing, M., 1959. The floors of the oceans, 1, the North Atlantic. Spec. Pap. Geol. Soc. Am., 65: $1-122$.

Howe, H. V., 1939. Louisiana Cook Mountain Eocene foraminifera. La. Dept. Conserv., Geol. Surv., Geol. Bull., 14:1-122.

Howe, H. V., and Wallace, W. E., 1932. Foraminifera of the Jackson Eocene at Danville Landing on the Ouachita, Catahoula Parish, Louisiana. Louisiana Dept. Conserv. Geol. Bull., 2.

Jones, G. D., 1982. Foraminiferal paleontology and geology of lower Claibornian rocks of inner coastal plain of North Carolina [Ph.D dissertation]. University of Delaware, Newark.

1983. Foraminiferal biostratigraphy and depositional history of the middle Eocene rocks of the coastal plain of North Carolina. Spec. Publ. N.C. Geol. Surv., 8.

Katz, M. E., and Miller, K. G., 1985. Effect of abyssal circulation changes on Oligocene to Miocene benthic foraminifera in the North Atlantic. Geol. Soc. Am. Abstr. Progr., 17:623.

Kominz, M. A., 1984. Oceanic ridge volumes and sea-level changean error analysis. In Schlee, J. (Ed.), Interregional Unconformities and Hydrocarbon Accumulation. Am. Assoc. Pet. Geol., 36:109127.

Lohmann, G. P., 1978a. Abyssal benthonic foraminifera as hydrographic indicators in the western South Atlantic Ocean. J. Foram. Res., 8:6-34.

$58-64$

1978b. Response of the deep sea to ice ages. Oceanus, 21:

1980. PATS-1, a package of programs for the analysis of marine micropaleontological data on the VAX 11/780 computer. Woods Hole Oceanogr. Inst. Tech. Rep., WHOI-80-27.

Luterbacher, H., 1972. Paleocene and Eocene planktonic foraminifera, Leg XI, Deep Sea Drilling Project. In Hollister, C. D., Ewing, J. I., et al., Init. Repts. DSDP, 11: Washington (U.S. Govt. Printing Office), $547-550$.

Mallory, V. S., 1959. Lower Tertiary Biostratigraphy of the California Coast Ranges: Tulsa, OK (Am. Assoc. Petrol. Geol.).

Martin, L. T., 1943. Eocene foraminifera from the type Lodo Formation, Fresno County, California. Standford Univ. Ser. Geol. Sci., 3(3):93-125

Matsunaga, T., 1955. Spirosigmoilinella, a new foraminiferal genus from the Miocene of Japan. Trans. Proc. Paleontol. Soc. Japan, 18:50.

Miller, K. G., 1983. Eocene-Oligocene paleoceanography of the deep Bay of Biscay: Benthic foraminiferal evidence. Mar. Micropaleontol., 7:403-440. 
Miller, K. G., Curry, W. B., and Ostermann, D. R., 1985. Late Paleogene (Eocene to Oligocene) benthic foraminiferal oceanography of the Goban Spur region, Deep Sea Drilling Project Leg 80. In Graciansky. P. C., de, Poag, C. W., et al, Init. Repts. DSDP, 80: Washington (U.S. Govt. Printing Office), 505-538.

Miller, K. G., Gradstein, F. M., and Berggren, W. A., 1982. Late Cretaceous to early Tertiary agglutinated benthic foraminifera in the Labrador Sea. Micropaleontology, 28(1):1-30.

Miller, K. G., and Lohmann, G. P., 1982. Environmental distribution of Recent benthic foraminifera on the northeast U.S. continental slope. Geol. Soc. Am. Bull., 93:200-206.

Miller, K. G., Mountain, G. S., and Tucholke, B. E., 1985. Oligocene glacio-eustasy and erosion on the margins of the North Atlantic. Geology, 13:10-13.

Nuttall, W. L. F., 1930. Eocene foraminifera from Mexico. J. Paleontol., 4:271-293.

Nyong, E. E., and Olsson, R. K., 1984. A paleoslope model of Campanian to lower Maestrichtian foraminifera in the North American basin and adjacent continental margin. Mar. Micropaleontol., 8: 437-477.

Olsson, R. K., and Nyong, E. E., 1984. A paleoslope model for Campanian-lower Maestrichtian foraminifera of New Jersey and Delaware. J. Foram. Res., 14(1):50-68.

Orbigny, A. d', 1839. Voyage dans l'Amérique méridonale; Foraminiféres (Vol. 5, Pt. 5): Strasbourg, France (Levrault), p. 56.

Parker, F. L., and Bermudez, P. J., 1937. Eocene species of the genera Bulimina and Buliminella from Cuba. J. Paleontol., 11(6):513-516.

Parsons, B., and Sclater, J. G., 1977. An analysis of the variation of ocean floor bathymetry and heat flow with age. J. Geophys. Res., 82:803-827.

Phleger, F. B., and Parker, F. L., 1951. Ecology of Foraminifera, northwest Gulf of Mexico, Pt. 2, Foraminifera species. Mem. Geol. Soc. Am., 46:1-64.

Phleger, F. B., Parker, F. L., and Peirson, J. F., 1953. Repts. Swed. Deep-Sea Exped. 1947-1948, 7(1):49.

Pitman, W. C., 1978. Relationship between eustasy and stratigraphic sequences of passive continental margins. Geol. Soc. Am. Bull., 89:1389-1403.

Poag, C. W., 1980. Foraminiferal stratigraphy, paleoenvironments, and depositional cycles in the outer Baltimore Canyon trough. In Scholle, P. A. (Ed.), Geological Studies of the COST No. B-3 Well, United States Mid-Atlantic Continental Slope Area. U.S. Geol. Surv. Circular, 833:44-65.

1985.Depositional history and stratigraphic reference section for Central Baltimore Canyon Trough. In Poag, C. W. (Ed.), Geologic Evolution of the U.S. Atlantic Margin: New York (Van Nostrand Reinhold), pp. 217-264.

Poag, C. W., Reynolds, L. A., Mazzullo, J. M., and Keigwin, L. D., Jr., 1985. Foraminiferal, lithic, and isotopic changes across four major unconformities at Deep Sea Drilling Project Site 548, Goban Spur. In Graciansky, P. C. de, Poag, C. W., et al., Init. Repts. DSDP, 80: Washington (U.S. Govt. Printing Office), 539-556.

Reuss, A. E., 1851. Über die fossilen Foraminiferen und Entomostraceen der Septarienthone der Umgegend von Berlin. Z. D. Geol. Ges., 3:71.

1855. Ein Beitrag zur genaueren Kenntniss der Kreidegebilde Meklenburgs. Z. D. Geol. Ges., 7(1):269.

Rzehak, A., 1895. Über einige merkwürdige Foraminiferen aus dem österreichischen Tertiär. Naturile Foraminiferen von Kar Nikobar. Novara Exped. 1857-1859. Geol. Theil (Wien Österreich), 2(2):249.
Schnitker, D., 1974. Western Atlantic abyssal circulation during the past 120,000 years. Nature, 248:385-387.

1979. Cenozoic deep water benthic foraminifers, Bay of Biscay. In Montadert, L., Roberts, D. G., et al. Init. Repts. DSDP, 48: Washington (U.S. Govt. Printing Office), 377-413.

Schwager, C., 1866. Fossile Foraminiferen von Kar Nikobar. Novara Exped. 1857-1859, Geol. Theil (Wien Österreich), 2(2):249.

Sclater, J. G., Anderson, R. N., and Bell, M. L., 1971. Elevation of ridges and evolution of the central Eastern Pacific. J. Geophys. Res., 76(32): 7888-7915.

Stainforth, R. M., Lamb, J. L., Luterbacher, H., Beard, J. H., and Jeffords, R. M., 1975. Cenozoic planktonic foraminiferal zonation and characteristics of index fossils. Univ. Kansas, Paleontol. Contr., Art. 62.

Streeter, S. S., 1973. Bottom water and benthonic foraminifera in the North Atlantic: Glacial-interglacial contrasts. Quat. Res., 3:131141.

Subbotina, N. N., 1953. Upper Eocene Lagenidae and Buliminidae of the southern U.S.S.R. Vses. Nert. Nauchno-Issled. Geol., Razved Inst. Microfauna of the U.S.S.R., Sbornik 6.

Thorne, J., and Watts, A. B., 1984. Seismic reflectors and unconformities at passive continental margins. Nature, 311(5984):365-368.

Tjalsma, R. C., 1983. Eocene to Miocene benthic foraminifers from Deep Sea Drilling Project Site 516, Rio Grande Rise, South Atlantic. In Barker, P. F., Carlson, R. L., Johnson, D. A., et al., Init. Repts. DSDP, 72: Washington (U.S. Govt. Printing Office), 731755.

Tjalsma, R. C., and Lohmann, G. P., 1983. Paleocene-Eocene bathyal and abyssal benthic foraminifera from the Atlantic Ocean. Spec. Publ. Micropaleontology, 4:90.

Trauth, F., 1918. Das eozänvorkommen bei Radstadt im Pongou und seine beziehungen zu den gleichalterigen Ablagerungen bie Kirchberg am Wechsel und Wimpassing am Leithagebirge. $K$. Acad. Wiss. Wien, Math.-Naturw. Kl., Denkschr. (Wien, Österreich), 95:235.

Tucholke, B. E., and Vogt, P. R., 1979. Western North Atlantic: Sedimentary evolution and aspects of tectonic history. In Tucholke, B. E., Vogt, P. R., et al. Init. Repts. DSDP, 43: Washington (U.S. Govt. Printing Office), 791-825.

Vail, P. R., Mitchum, R. M., Todd, R. G., Widmier, J. M., Thompson, S., III, Sangree, J. B., Bubb, J. N., and Hatlelid, W. G., 1977. Seismic stratigraphy and global changes of sea level. In Payton, C. E. (Ed.), Seismic Stratigraphy-Applications to Hydrocarbon Exploration. Mem. Am. Assoc. Petrol. Geol. 26:49-205.

Watts, A. B., and Steckler, M. S., 1979. Subsidence and eustasy at the continental margin of eastern North America. In Talwani, M., Hay, W., and Ryan, W. B. F. (Eds.), Deep Drilling Results in the Atlantic Ocean: Continental Margins and Paleoenvironment. Am. Geophys. Union, Maurice Ewing Series, 3:218-234.

Wood, K. C., Miller, K. G., and Lohmann, G. P., 1985. Middle Eocene to Oligocene benthic foraminifera from the Oceanic Formation, Barbados. Micropaleontology, 31:181-197.

Date of Initial Receipt: 7 July 1985

Date of Acceptance: 8 January 1986 


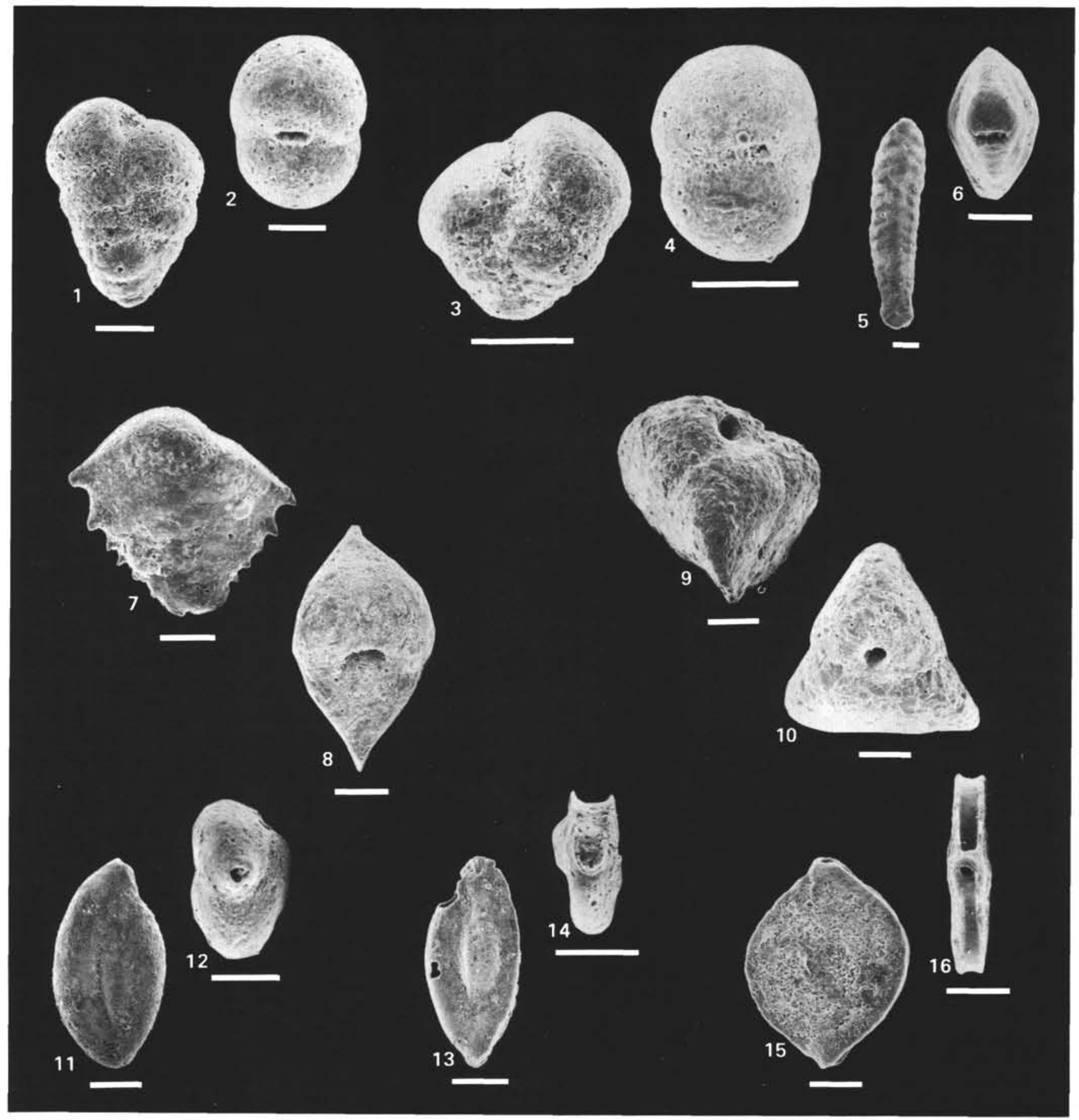

Plate 1. (Scale bar $=100 \mu \mathrm{m}$.) 1, 2. Karreriella subglabra (Guembel), Sample 612-21-3, 60-64 cm. 3, 4. K. chapapotensis var. monumentensis Mallory, Sample 612-21-3, 60-64 cm. 5, 6. Spiroplectammina spectabilis (Grzybowski), Sample 612 33,CC. 7, 8. Vulvulina spinosa Cushman, Section 612-28-6, base. 9, 10. Gaudryina pyramidata Cushman, Sample 612-17-6, 140-144 cm. 11, 12. Sigmoilopsis sp., Sample 612$17-5,140-144 \mathrm{~cm} .13,14$. Spirosigmoilinella compressa Matsunaga, Sample 612-20,CC. 15, 16. Rezehakina epigona (Rzehak), Sample 612$45-3,60-64 \mathrm{~cm}$. 


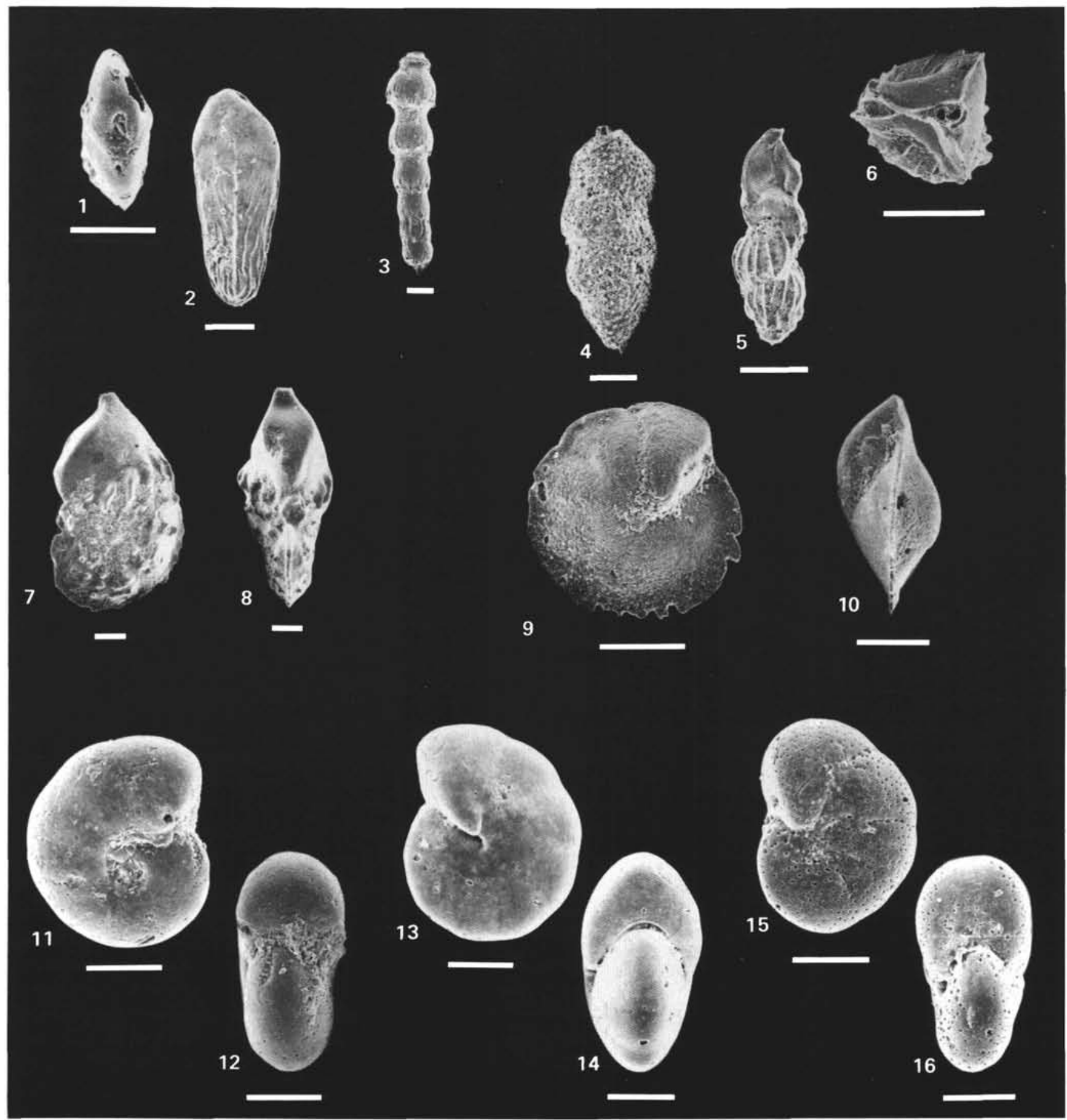

Plate 2. (Scale bar $=100 \mu \mathrm{m}$.) 1, 2 Bolivina antegressa Subbotina, Sample 612-16,CC. 3. Stilostomella curvatura (Cushman), Sample 612-17-2, 140-144 cm. 4. Uvigerina hispida Schwager, Sample 612-18,CC. 5, 6. Trifarina wilcoxensis (Cushman and Ponton), Sample 612-17-6, 140$144 \mathrm{~cm}$. 7, 8. Vaginulina $\mathrm{cf}$. decorata (Reuss), Sample 612-45-3, 60-64 cm. 9, 10. Osangulara mexicana (Cole), Sample 612-17-5, 140-144 cm 11, 12. Anomalinoides sp. M, Sample 612-30,CC. 13, 14. Nonion havanense Cushman and Bermudez, Sample 612-18-3, 60-64 cm. 15, 16. Nonionellina sp., Sample 612-18-3, 60-64 cm. 


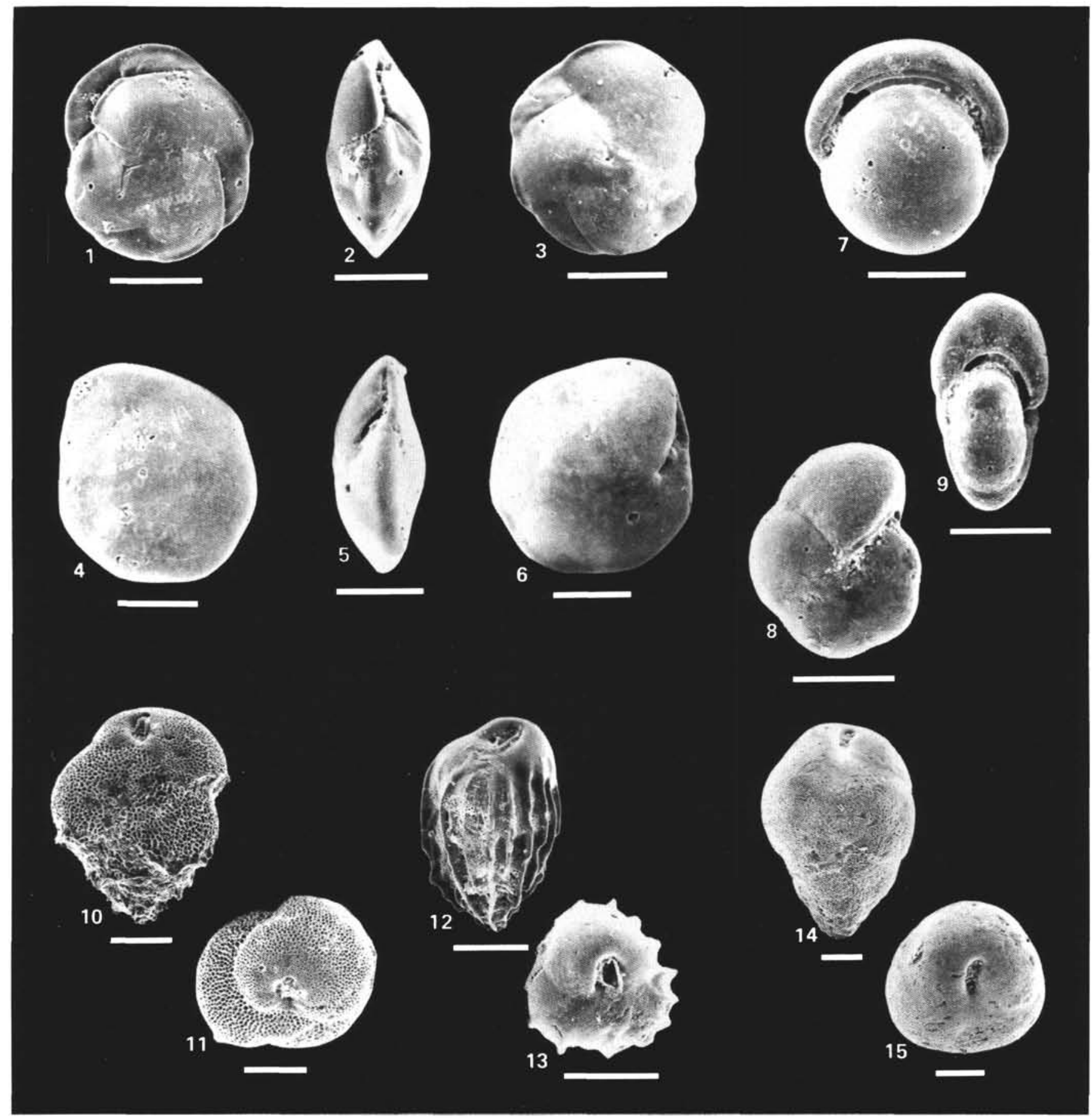

Plate 3. (Scale bar $=100 \mu \mathrm{m}$.) 1-3. Cassidulina havanensis Cushman and Bermudez, Sample 612-19-3, 60-64 cm. 4-6. Alabamina cf. dissonata (Cushman and Renz), Sample 612-17-3, 140-143 cm. 7. Pullenia eocenica Cushman and Siegfus, Sample 612-17-4, 60-64 cm. 8, 9. P, quniqueloba (Reuss), Sample $612-17-6,140-144 \mathrm{~cm}$. 10, 11. Bulimina trinitatensis Cushman and Jarvis, Sample 612-18,CC. 12, 13. B. alazanensis Cushman, Sample 612-16,CC. 14, 15. B.Tuxpamensis Cole, Sample 612-17-3, 140-143 cm. 


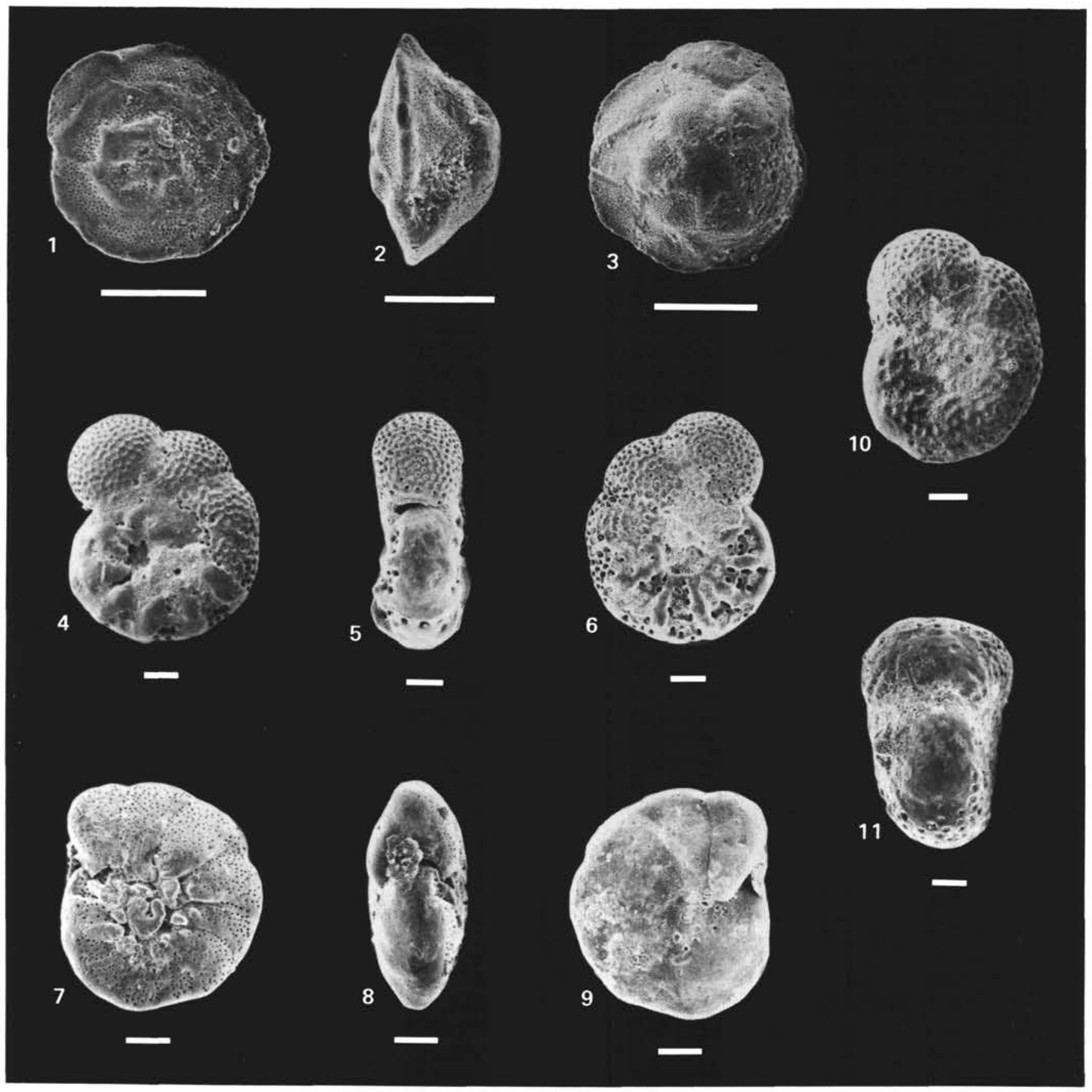

Plate 4. (Scale bar $=100 \mu \mathrm{m}$.) 1-3. Nuttallides truempyi (Nuttall), Sample 612-24,CC. 4-6. Gavelinella capitata (Guembel) var. aragonensis (Nuttall), Sample 612-41-3, 60-64 cm. 7-9. G. micra (Bermudez), Sample 612-26,CC. 10, 11. G. capitata (Guembel), Section 612-28-6, base. 


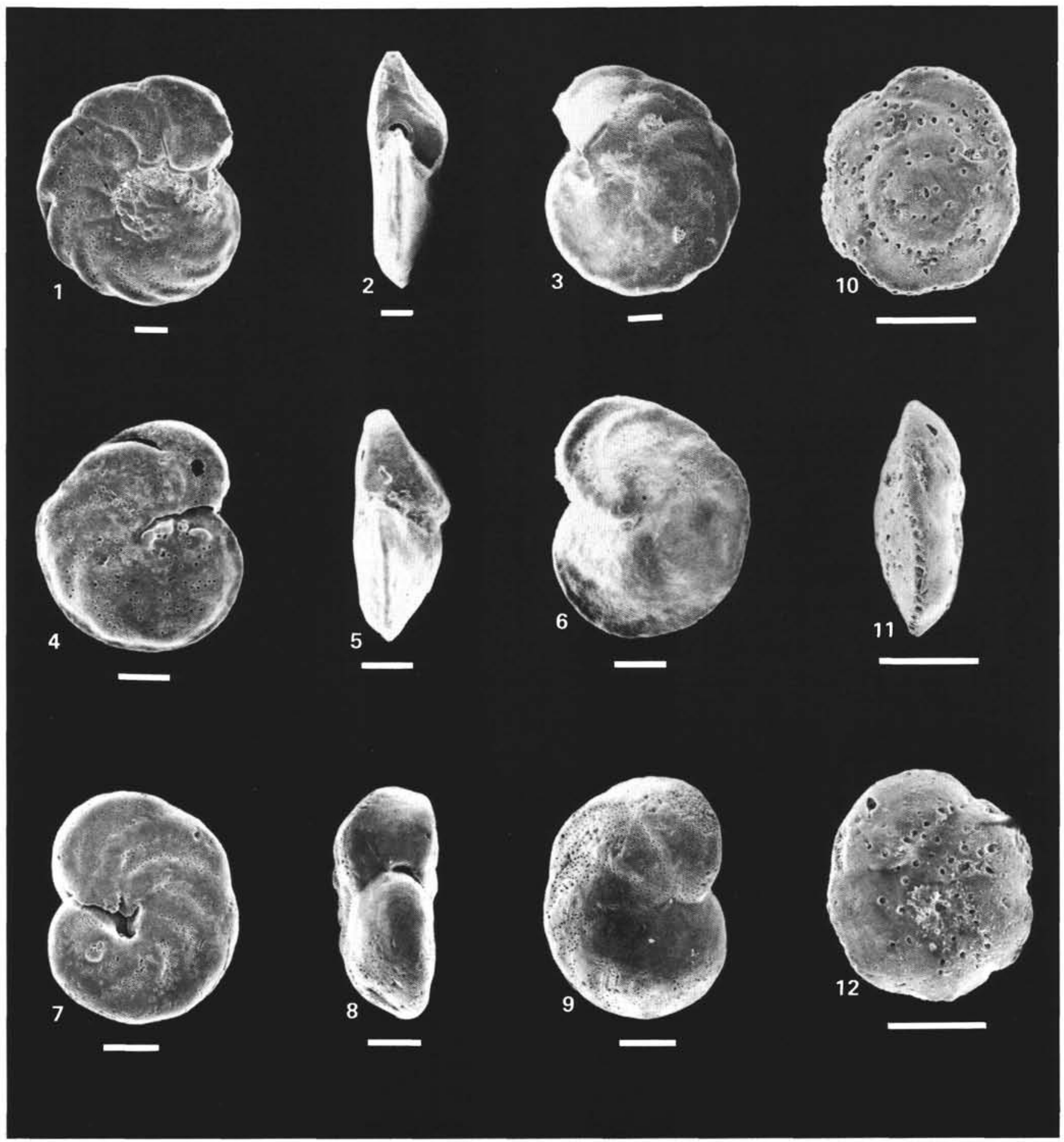

Plate 5. (Scale bar $=100 \mu \mathrm{m}$.) 1-3. Planulina costata (Hantken), Sample 612-20,CC. 4-6. P. cf. renzi Cushman and Stainforth, Sample 61216,CC. 7-9. Hanzawaia ammophila (Guembel), Sample 612-18-3, 60-64 cm. 10-12. Siphonina sp., Sample 612-39-3, 60-64 cm. 

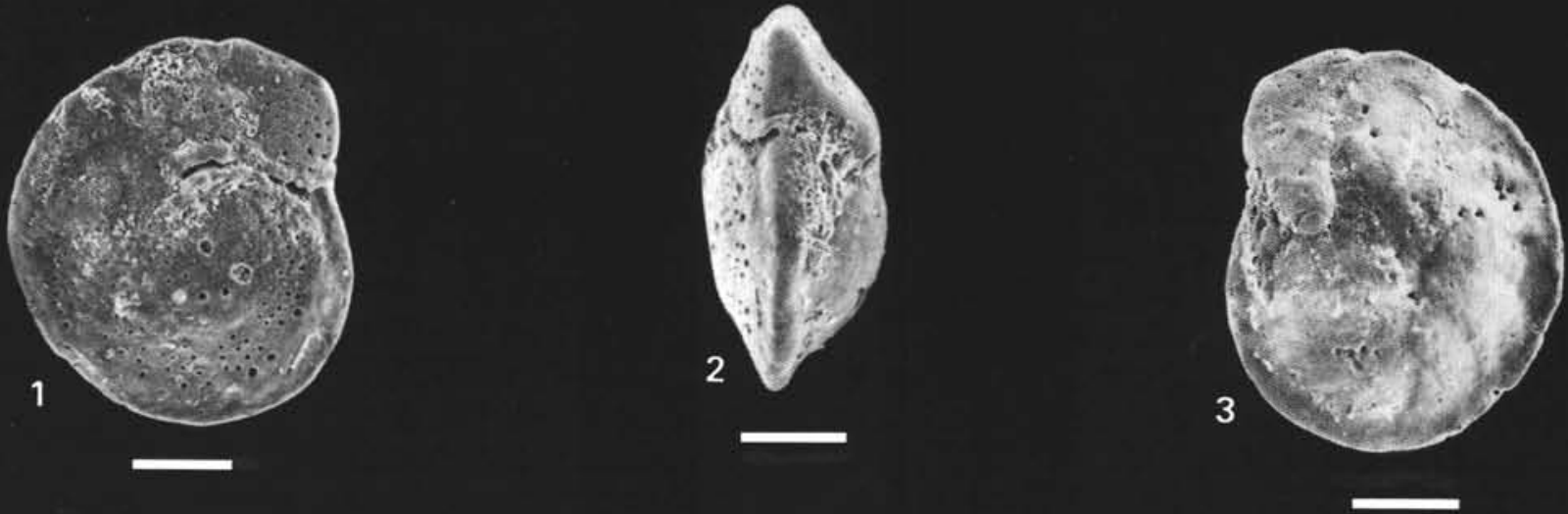

4

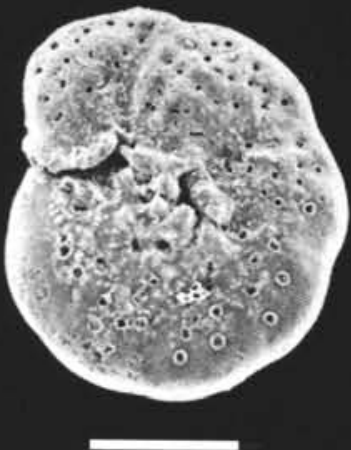

7

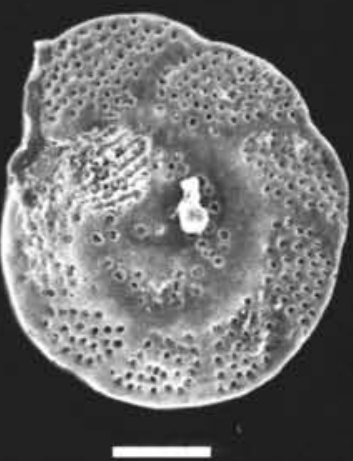

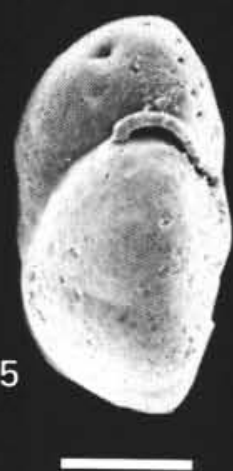
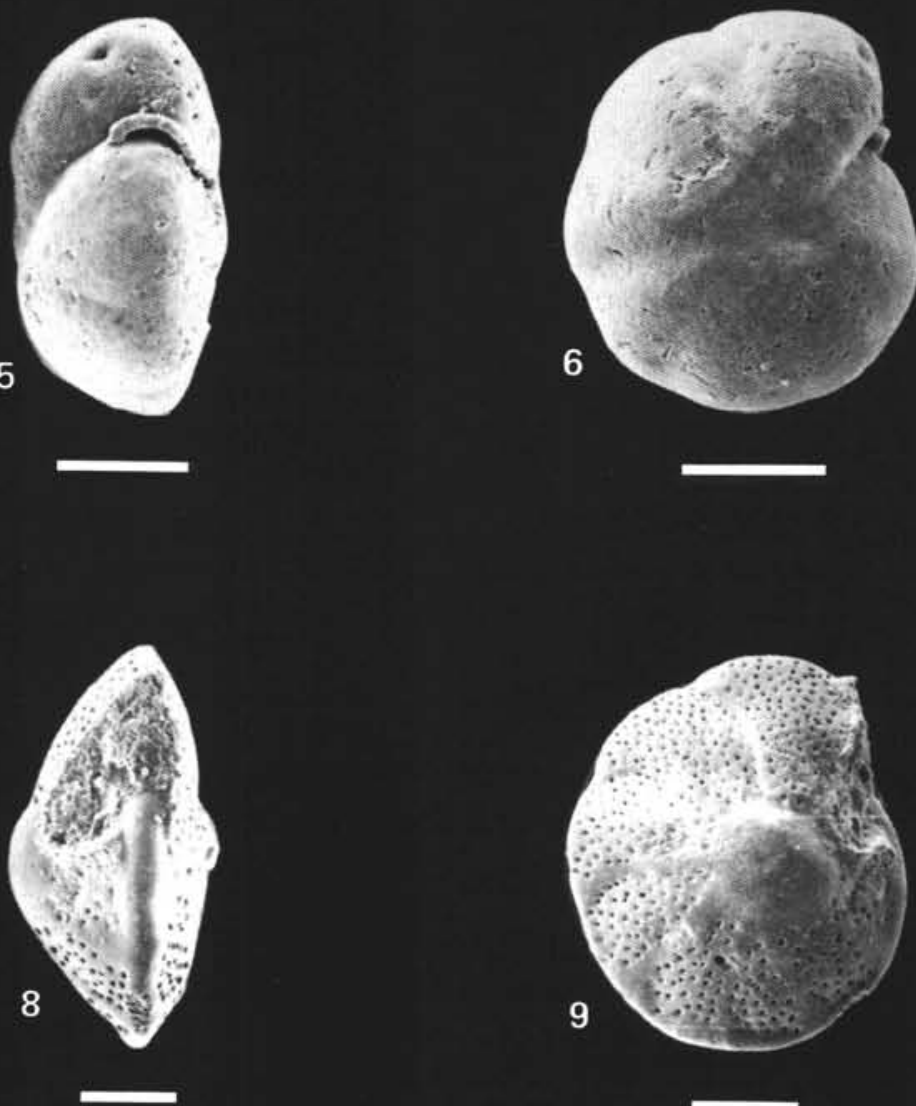

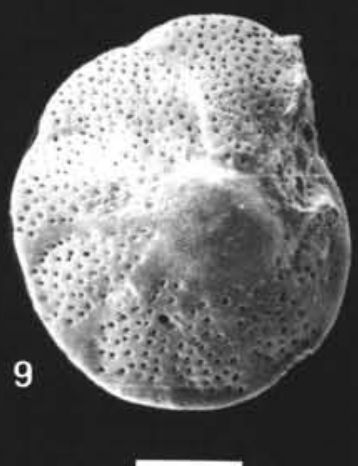

Plate 6. (Scale bar $=100 \mu \mathrm{m}$.) 1-3. Cibicidoides mundulus group, Sample 612-22,CC. 4-6. Cibicidoides sp. D. Sample 613-20,CC. 7-9. Cibicidoides tuxpamensis (Cole), Sample 612-41-3, 60-64 cm. 


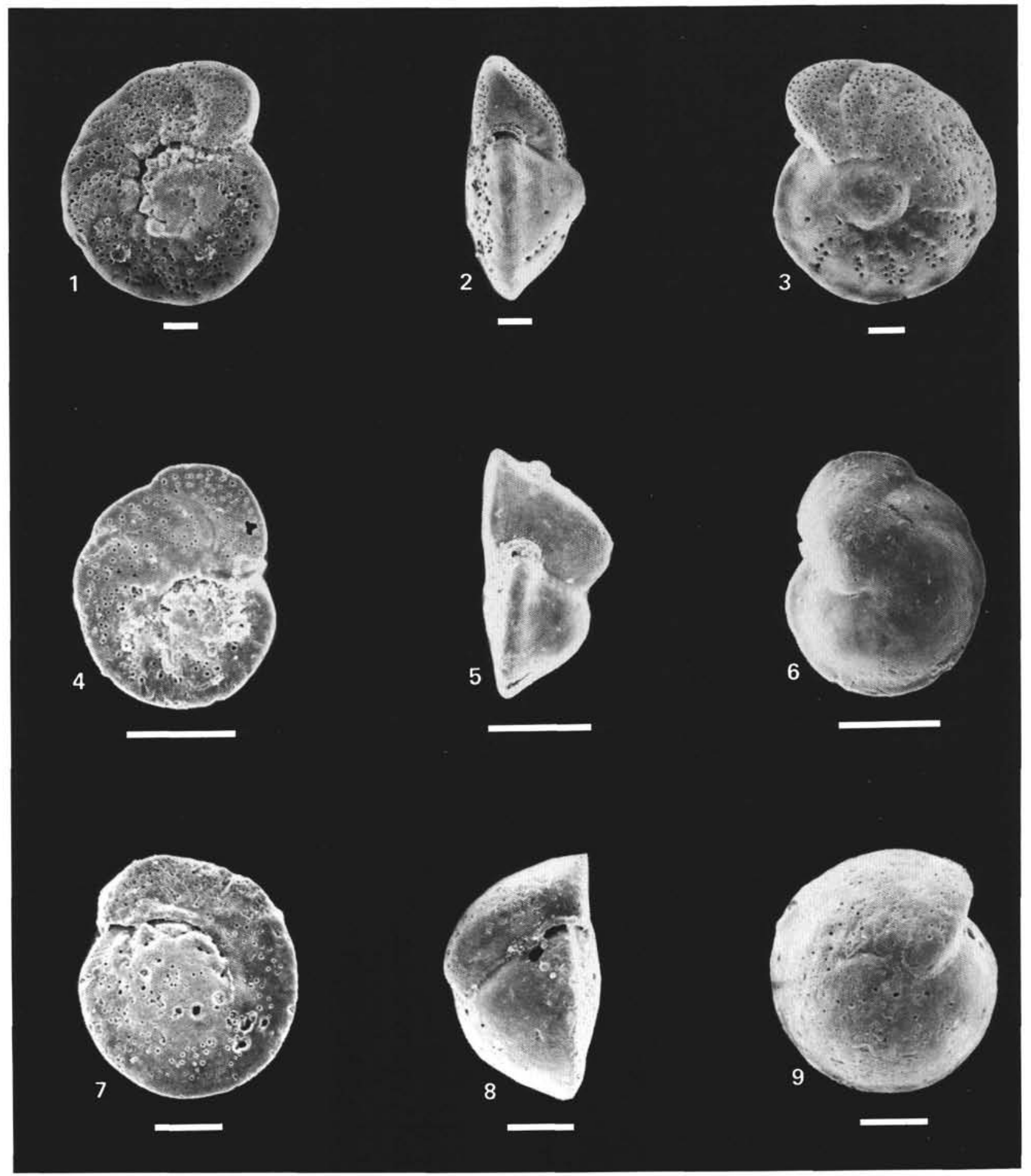

Plate 7. (Scale bar $=100 \mu \mathrm{m}$.) 1-3. Cibicidoides sp. P, Sample 612-17-4, 60-64 cm. 4-6. C. laurisae (Mallory), Sample 612-20,CC. 7-9. C. subspiratus (Nuttall), Sample 613-30,CC. 